\title{
Computer-supported collaborative learning in clinical clerkships
}

Citation for published version (APA):

Koops, W. J. M. (2016). Computer-supported collaborative learning in clinical clerkships: profits of an online asynchronous discussion forum for medical students during workplace learning. [Doctoral Thesis, Maastricht University]. Datawyse / Universitaire Pers Maastricht. https://doi.org/10.26481/dis.20160608wk

Document status and date:

Published: 01/01/2016

DOI:

10.26481/dis.20160608wk

Document Version:

Publisher's PDF, also known as Version of record

\section{Please check the document version of this publication:}

- A submitted manuscript is the version of the article upon submission and before peer-review. There can be important differences between the submitted version and the official published version of record.

People interested in the research are advised to contact the author for the final version of the publication, or visit the DOI to the publisher's website.

- The final author version and the galley proof are versions of the publication after peer review.

- The final published version features the final layout of the paper including the volume, issue and page numbers.

Link to publication

\footnotetext{
General rights rights.

- You may freely distribute the URL identifying the publication in the public portal. please follow below link for the End User Agreement:

www.umlib.nl/taverne-license

Take down policy

If you believe that this document breaches copyright please contact us at:

repository@maastrichtuniversity.nl

providing details and we will investigate your claim.
}

Copyright and moral rights for the publications made accessible in the public portal are retained by the authors and/or other copyright owners and it is a condition of accessing publications that users recognise and abide by the legal requirements associated with these

- Users may download and print one copy of any publication from the public portal for the purpose of private study or research.

- You may not further distribute the material or use it for any profit-making activity or commercial gain

If the publication is distributed under the terms of Article $25 \mathrm{fa}$ of the Dutch Copyright Act, indicated by the "Taverne" license above, 


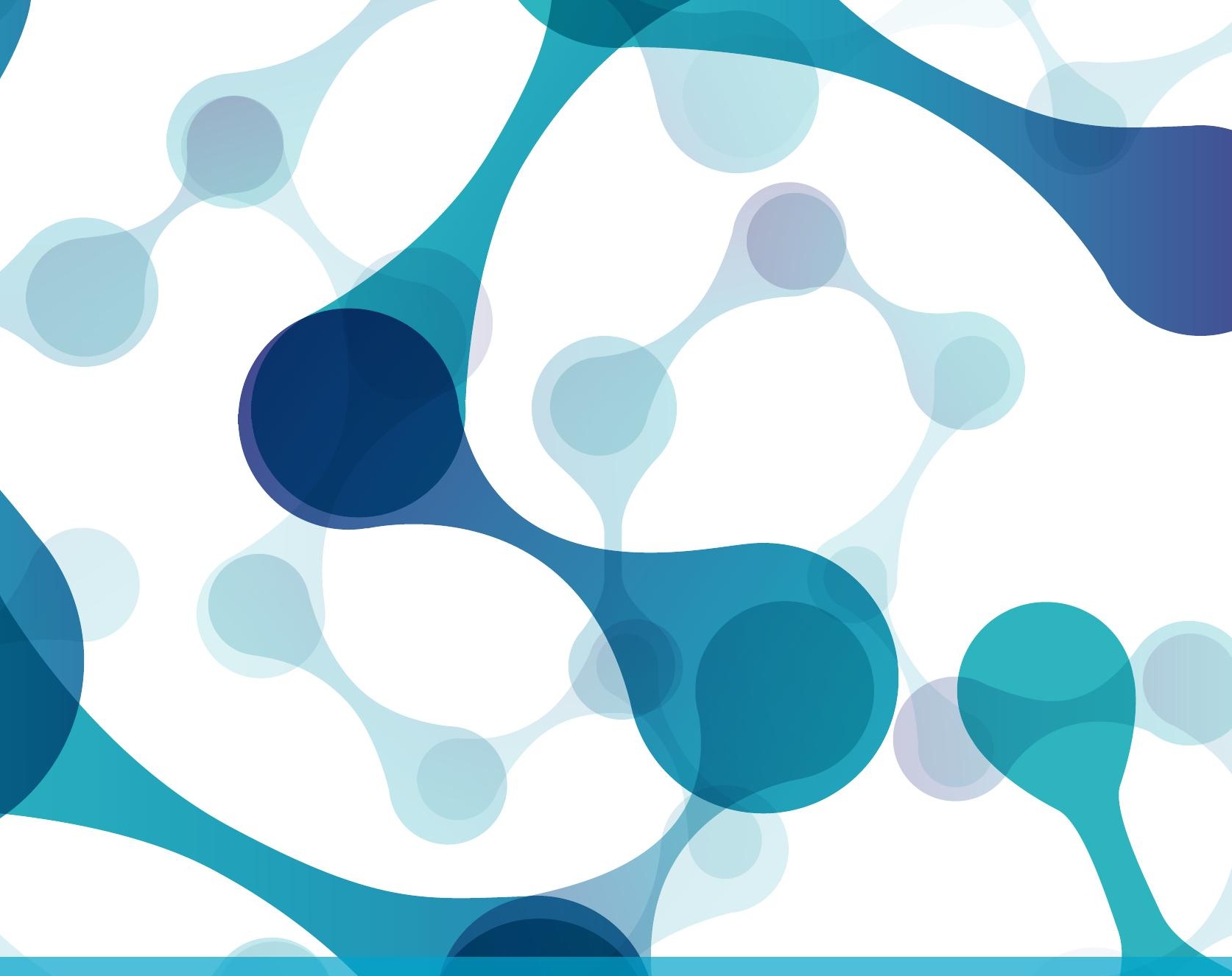

Computer-supported collaborative learning in clinical clerkships

Profits of an online asynchronous discussion forum for medical students during workplace learning

Willem Koops 
Printing of this thesis was financially supported by Máxima Medical Center.

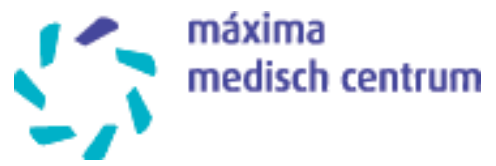




\title{
Computer-supported collaborative learning in clinical clerkships
}

\section{Profits of an online asynchronous discussion forum for medical students during workplace learning}

\author{
PROEFSCHRIFT \\ ter verkrijging van de graad van doctor aan de Universiteit Maastricht, \\ op gezag van de Rector Magnificus, Prof. Dr. L.L.G. Soete \\ volgens het besluit van het College van Decanen, \\ in het openbaar te verdedigen \\ op woensdag 8 juni 2016 om 16:00 uur
}

door

Willem Johannes Martijn Koops 


\section{Promotores}

Prof. Dr. C.P.M. van der Vleuten

Prof. Dr. L.H.E.H. Snoeckx

\section{Copromotor}

Dr. B.A. de Leng, Westfälische Wilhelms-Universität, Münster, Duitsland

\section{Beoordelingscommissie}

Prof. Dr. M.G.A. oude Egbrink, voorzitter

Prof. Dr. G. Croiset, VUmc, School of Medical Sciences, Amsterdam

Prof. Dr. A.F.P.M. de Goeij

Prof. Dr. S. Heeneman

Prof. Dr. M. Valcke, Ghent University, Gent, België 


\section{Table of contents}

\section{General introduction}

2 Clinical clerkship students' experiences on peer feedback of a task by computer-supported collaborative learning environment.

Published as: Willem J. M. Koops, Cees P. M. van der Vleuten, Bas A. de Leng, S. Guid Oei, Luc H.E.H. Snoeckx. Computer-supported collaborative learning in the medical workplace: Students' experiences on formative peer feedback of a critical appraisal of a topic paper. Medical Teacher 2011;33:6:e318-e323. DOI: 10.3109/0142159X.2011.575901.

3 Clinical clerkship students' perceptions and the effect of knowledge construction on learning outcome by a computer-supported collaborative learning environment.

Published as: Willem J.M. Koops, Cees P.M. van der Vleuten, Bas A. de Leng, Saskia Houterman, Luc H.E.H. Snoeckx. Computer-supported Collaborative Learning at the Clinical Workplace: Students' Perceptions and the Effect of Knowledge Construction on Learning Outcome. Journal of Contemporary Medical Education 2014; 2(2): 71-78. DOI: 10.5455/jcme.20140118055300.

4 The relation of clinical clerkship students' discussion activity and task revision by a computer-supported collaborative learning environment

Published as: Willem J.M. Koops, Cees P.M. van der Vleuten, Bas A. de Leng, Luc H.E.H. Snoeckx. Computer Supported Collaborative Learning in a clerkship: An exploratory study on the relation of discussion activity and revision of critical appraisal papers. BMC Medical Education 2012, 12:79. DOI:10.1186/1472-6920-12-79.

5 The positive effect of feedback by multiple peers on clinical clerkship students' task revision by a computer-supported collaborative learning environment.

Under editorial review of BMC Medical Education as: Willem J.M. Koops, Cees P. M. van der Vleuten, Luc H.E.H. Snoeckx. Computer-Supported Collaborative Learning by medical students: The positive effect of feedback by multiple peers.

6 General discussion and conclusions

Summary

Samenvatting

Valorisatie hoofdstuk

Dankwoord

Curriculum Vitae 




\section{INTRODUCTION}

\section{Social-constructivism}

In the last decades the view on learning and instruction in higher education has changed radically. Traditional teacher-centered learning activities have been gradually substituted by more student-centered learning activities based on the view that students are perfectly capable to self-direct their learning (Veerman 2000; Van der Meijden 2005; Laurillard 2002). This approach is derived from the educational theory of constructivism that focuses on a dynamic and student-centered learning process where students actively construct knowledge (Veldhuis-Diermanse 2002). Knowledge construction comprises of adding, elaborating and evaluating ideas, summarizing and evaluating external information, and linking different facts and new ideas or concepts on the current and previous knowledge of the individual student (Veldhuis-Diermanse 2002; Madizadeh 2007; De Wever 2006c; Veerman 2000; Van Amelsvoort 2006).

Cognitive constructivism, originally described by Piaget (Van der Meijden 2005), assumes that learning is an active construction of a person's mental model. These models are continuously open for change and affected by each new experience that an individual perceives, from which arises a 'cognitive conflict'. Such a conflict promotes the student to (re)construct existing knowledge. Individual knowledge construction is seen as an internal, unobservable process resulting in changes of belief, attitudes and/or skills (Van der Meijden 2005; De Wever 2006c; Veldhuis-Diermanse 2002; Madizadeh 2007; Veerman 2000; Van Amelsvoort 2006; Du et al. 2008).

Where Piaget (Van der Meijden 2005), describes knowledge construction as an internal and individual process, Vygotsky (Van der Meijden 2005) considers knowledge construction as an external and social process better known as social constructivism. This theory emphasizes that students feel challenged to actively construct new knowledge when they are situated in an ill-structured realistic setting in which no immediate right solution is at hand, also called the 'zone of proximal development' (Madizadeh 2007; Veerman 2000; Veldhuis-Diermanse 2002; Brown et al. 1988; Kirschner 2001; De Wever 2006c; Van der Meijden 2005, Van Amelsfoort 2006; Cobb et al. 2001; Du et al. 2008). By learning collaboratively, students are stimulated to play a more active role in their own learning process and those of their peers. As such, collaborative learning focusses on the process of learning as a joint intellectual effort, instead of focusing on the product only (De Wever 2006c; Panitz 1999; Kirschner et al. 2001; Mahdizadeh 2007).

In a physical classroom environment, collaborative learning can easily be organized. However, in a workplace environment where students are physically dispersed in time and place, it is much harder to organize collaborative learning efficiently. 
During workplace learning, collaborative learning is potentially valuable as well, for in such a work-based environment students encounter several problems that are real and relevant to them as well as to their peers. However, students often still learn individually from these unique personal work-based experiences (O'Brien et al. 2010; Chittenden et al. 2009). By enabling students to share these experiences and to use them to learn, they profit from collaborative learning (Collis et al. 2004; Manley et al. 2009).

\section{Computer-supported collaborative learning.}

In order to create an additional value to collaborative learning within workplace learning, the introduction and use of an on-line computer supported collaborative learning (CSCL) environment can be very beneficial. This is because all individual work-based experiences can be shared and discussed, creating an additional source for broad and deep learning. Such an environment has been specifically designed to promote collaboration for small groups working at a distance. The technical difficulties of efficient collaborative work-based learning can also easily be tackled through the use of a CSCL environment. CSCL is based on the social-constructivist view of learning by facilitating social interaction by a structured asynchronous peer discussion forum between group members (Veldhuis-Diermanse 2002, Scardamalia et al. 1994; Mahdizadeh 2007; De Wever 2006c; Dewiyanti 2005; Van der Meijden 2005). A group of students using an asynchronous discussion forum in a CSCL environment offers several advantages to collaborative learning.

The first is that it forces students to externalise their knowledge construction process. During an asynchronous discussion forum in a CSCL environment students criticize their own contributions as well as those from peers, ask for explanations, provide counterarguments, and explain a problem (Mahdizadeh 2007; Stahl 2003, VeldhuisDiermanse 2002; Veerman 2000). These activities of students thinking are made visible by writing down ideas and by explaining insights (Van der Meijden 2005; VeldhuisDiermanse 2002; De Wever 2006c; Stahl 2003, Mahdizadeh 2007). Such a conversation history can be used to track student' development in reflection and debate (VeldhuisDiermanse 2002; De Wever et al. 2006b; De Wever 2006c; Weinberger et al. 2005). For research purposes analysis of discussion transcripts of students' knowledge construction process can be conducted (Veldhuis-Diermanse 2002, Baker et al. 2007; Hewitt et al. 1998; Veerman 2000; De Wever et al. 2006b; Van der Meijden 2005).

The second advantage is that an asynchronous discussion forum provides extra time to think, reflect, and search for additional information before participating in the discussion (De Wever 2006c; Pena-Shaff et al. 2004; Van der Meijden 2005). As a consequence such discussions are more thoughtful and reflective, and encourage active learning, participation, interaction, negotiation, and dialogue as well (De Wever 2006c; Dewiyanti 2005; Van der Meijden 2005; Mahdizadeh 2007). 
Thirdly, the focus of an asynchronous discussion forum lies more on the message than on the writer.

Indeed, students feel more free to 'speak' because cultural differences and social cues to status are better masked (De Wever 2006c). Compared to a real-time 'face to face' discussion, an asynchronous discussion forum guarantees a better participation of all group members (Dewiyanti 2005).

Fourth, an asynchronous discussion forum offers valuable ways of structuring a discussion in threads. Such structured discussions encourage students to focus on specific parts of the communication or problem-solving and lead to an increase of taskoriented behaviour (Dewiyanti 2005; Veldhuis-Diermanse 2002; Baker et al. 1997).

Finally, via an asynchronous discussion forum, students are able to collaborate at a distance and at the time they prefer to study. This increases the accessibility to learning, opportunities for interaction, educational flexibility, and physical independency (De Wever 2006c, Dewiyanti 2005; Van Der Meijden 2005; Veldhuis-Diermanse 2002; Mahdizadeh 2007).

It has been proven that a CSCL environment is not only promising to connect students to learn collaboratively, but that it is very effective to students learning as well. Positive students' perceptions on a forum discussion task within a CSCL environment are acknowledged to be important for its effectiveness (Dewiyanti 2005; Mahdizadeh 2007; Laurillard 2002; Morrison et al. 2004). Indeed, a positive perception fosters active knowledge construction by stimulating critical thinking, deeper-level learning and shared understanding in a social manner (Kreijns et al. 2005; Dewiyanti 2005; Van Der Meijden 2005). Several studies performed among students in higher education are indicative for a positive perception of discussing problems asynchronously within a forum in a CSCL environment (Campagnolo et al. 2003; Spickard et al. 2004; Steele et al. 2002; Strøms $\varnothing$ et al. 2004, Singh et al. 2011). For instance, when working in small groups, students report that the intensity and quality of communication with tutors and peers is highly appreciated, and that the attitude towards collaborative learning significantly improves after asynchronous discussion forum (De Wever 2006c; Taradi et al. 2008; Masiello et al. 2005; Nathoo et al. 2005; May et al. 2009; Leong et al. 2003; Heath et al. 2008; Peska et al. 2010; Servais et al. 2006; Lillis et al. 2010; Van Der Meijden 2005).

It is also important to know whether or not students' knowledge has been improved after collaborating within a forum in a CSCL environment. Some studies claim students perceived knowledge improvement after conducting an assignment in an asynchronous discussion forum (Schilling et al. 2006; Shah et al. 2008; Raupach et al. 2010; Dewiyanti 2005) however, it should be realized that students' perception of knowledge improvement is rather a subjective indicator. A study by Williams and colleagues (2001) demonstrates clearly that a positive perception on knowledge improvement after participating in an asynchronous discussion forum in a CSCL environment is not necessarily matched by an objective measurement on knowledge tests. The literature on self-assessment shows similar outcomes (Eva et al. 2005). 
In higher education, the results of research on objective knowledge improvement by an asynchronous discussion forum in a CSCL environment are scattered and sometimes contradictory. Some studies report significant knowledge improvement when students participate in an asynchronous discussion forum in a CSCL environment (Taradi et al. 2004; Wiecha et al. 2006; Kamin et al. 2002; Taradi et al. 2008; Heath et al. 2008; Servais et al. 2006; Bernardo et al. 2004), whereas other studies do not find differences in knowledge improvement (Bowdish et al. 2003; Raupach et al. 2009).

Students' knowledge improvement after an asynchronous discussion forum in a $\mathrm{CSCL}$ environment is influenced by the intensity of their activity within the collaborative learning process (Kreijns et al. 2005; Dillenbourg et al. 2009; Wang et al. 2000). During the learning process within an asynchronous discussion forum students construct knowledge by making their thinking visible by providing feedback to peers (Van Der Meijden 2005; Veldhuis-Diermanse 2002; De Wever 2006c; Stahl 2003, Mahdizadeh 2007; Du et al. 2008). Content-analysis of peer feedback, mostly expressed by discussion postings, provides insight in the level of students' knowledge construction (Veldhuis-Diermanse 2002, Baker et al. 2007; Hewitt et al. 1998; Veerman 2000; De Wever et al. 2006b; De Wever 2006c; Van Der Meijden 2005; Weinberger et al. 2005). Students' social interaction and task-focussed activity can be analysed as an expression of the level of the knowledge construction process during an asynchronous discussion forum (Schellens et al. 2006; De Wever et al. 2006b; De Wever 2006c).

The process of actively collaborating students that provide unauthorized feedback to each other does not only influence knowledge construction in an asynchronous discussion forum in a CSCL environment. The type of peer feedback that is delivered is important as well. Outside the scope of CSCL, research by Cho and colleagues (2006), classifies feedback into seven types: 'directive comments', 'non-directive comments', 'criticism comments', 'praise comments', 'summary comments', and 'off-task comments'. Cho et al. (2006) describes that students' providing each other with effective types of feedback enable criticism and reflection upon own work and that from their fellow students. By reviewing each other's tasks, the product can be revised resulting in an improved quality (Cho et al. 2006). Moreover, peer review on the content of a product appears to be at least as good as expert review (Topping 1998). A reason could be that peers live and work in comparable circumstances, share the same language and knowledge and are more familiar with the difficulties their fellow students may struggle with. When peers provide each other with feedback both provider and receiver might understand their feedback in a better way (Vedder 1985, Cho et al. 2010). Peers might benefit even more from peer feedback when multiple peers provide feedback on the same task. Feedback by multiple peers is more reliable and valid than single peer feedback because more problems, omissions and blind spots are detected. Feedback from various sources also minimizes the negative impact of incorrect remarks because the collective consensus tends to be perceived as valid or true (Cho et al. 2010). 


\section{Chapter 1}

\section{Medical Education}

In medical education multiple peer feedback is not common. Especially during workplace learning, a significant portion of the medical training program, medical students learn mostly individually from encountered working experiences. These experiences are clinical problems that are real and relevant to them as well as to their peers. Under such circumstances learning collaboratively could offer an additional value to stimulate knowledge construction. Medical students can learn collaboratively by actively discussing work-based experiences with the use of a CSCL environment, even when they are scattered over different clerkships.

Aside from one study by De Wever and colleagues (2006a) on learning outcome in pediatric interns using an asynchronous discussion forum in a CSCL environment, there is a paucity of research evidence regarding discussion of work-based experiences in collaborative learning using a CSCL environment. For instance, it is essentially unknown how medical students appreciate the use of an asynchronous discussion forum in a $\mathrm{CSCL}$ environment to learn collaboratively on workplace experiences and how they perceive knowledge improvement (learning outcome) under these circumstances. Furthermore, we are not aware whether these student perceptions can be confirmed by objective measurements of the level of knowledge improvement. Finally, it is unknown whether skilled medical students in the final phase of their education, who use an asynchronous discussion forum in a CSCL environment for workplace-related problemsolving are able to deliver both quantitative and qualitative peer feedback leading to a product improvement without expert interference. Therefore, the aim of present dissertation focusses on 4 aspects of an asynchronous discussion forum in a CSCL environment with medical students: students' perceptions; knowledge improvement; knowledge construction, and peer and expert feedback, 


\section{MAIN RESEARCH QUESTION.}

As such, the principal question of this dissertation is:

Does asynchronous discussion forum in a CSCL environment positively contribute to the learning process of medical students' conducting a clinical clerkship?

This question can be differentiated in four sub-questions:

1) How do medical students interact and what are their perceptions on the instructional quality of the asynchronous discussion forum in a CSCL environment.

2) Are medical students' perceptions on knowledge improvement after conducting a task in an asynchronous discussion forum of a CSCL environment confirmed by an objective measurement of knowledge improvement.

3) What is the level of knowledge construction by medical students while participating in an asynchronous discussion forum in a CSCL environment and how is it affected by the intensity of students' participation activity.

4) What is the effect of feedback by multiple peers on the quality of a task using an asynchronous discussion forum in a CSCL environment

\section{OVERVIEW OF THIS DISSERTATION.}

Chapter 2 describes the answers to sub-question 1. We explored whether CSCL-enabled structured asynchronous discussions on an authentic task has additional value for learning in the medical workplace. Students' perceptions of the CSCL arrangement were questioned with respect of their preparation and participation, forum design and perceived knowledge improvement. Furthermore, we analyzed students' discussion postings to explore how students interact during a CSCL discussion.

In chapter 3 we focus on sub-questions 1 and 2. We explored medical students' perceptions of the CSCL arrangement, and concentrated on knowledge improvement (learning outcome). We explored how students construct knowledge during a CSCL discussion and whether medical students' knowledge improvement on both their perception and their marks was positively improved.

Chapter 4 explores the relation between medical students' discussion activity and the possible revision of discussed written tasks (sub-question 2 and 3). We examined whether students who revise their task after participating in a structured an asynchronous discussion within a CSCL environment discuss more intensively and show higher levels of knowledge construction than students who do not revise their papers. 


\section{CHAPTER 1}

Sub-question 4 is answered in Chapter 5 where we describe the effect of feedback by multiple peers provided in an asynchronous discussion within a CSCL environment. We focused on multiple peer feedback leading to revision of tasks of such good quality that it obviates, either entirely or in part, the need for expert feedback. In this study we sought to explore three various phases of task review: 1) feedback on the task by multiple peers on a forum of a CSCL environment, 2) task revision ensuing from feedback by multiple peers, and 3) expert feedback on the task afterwards.

Chapter 6 provides a general discussion and main conclusions of this dissertation. Strengths and the limitations of the dissertation will be presented as well as recommendations for further research.

The chapters 2-5 of this dissertation are based on articles published or submitted to peer-reviewed scientific journals. They can be read as individual articles and therefore, some repetition of information between different chapters may occur. 


\section{REFERENCES}

- $\quad$ Baker, M., Lund, K. Promoting reflective interactions in a CSCL environment. Journal of Computer Assisted Learning. 1997; 13,175-193

- Baker, M., Andriessen, J., Lund, K., Amelsvoort, van, M., Quignard, M. Rainbow: A framework for analysing computer-mediated pedagogical debates. Computer-Supported Collaborative Learning. 2007; 2,315-357. DOI: 10.1007/s11412-007-9022-4.

- Bernardo , V., Ramosa, M., Plapler, H., de Figueiredo L., Nader, H., Silva Anção, M., von Dietrich, C., Sigulem, D. Web-based learning in undergraduate medical education: development and assessment of an online course on experimental surgery. International Journal of Medical Informatics. 2004; 73,731-742. DOI: 10.1016/j.ijmedinf.2004.06.002.

- Bowdish, B., Chauvin, S., Kreisman, N., Britt, M. Travels towards Problem Based Learning in Medical Education (VPBL). Instructional Science. 2003; 31,231-253.

- Brown, J., Collins, A., Duguid, P. 1988 Situated Cognition and the Culture of Learning Institute for Research on Learning. report no. IRL 88-0008, \& Beranek and Newman Inc. Research report 6895.

- Campagnolo, D., Stier, K., Sanchez, W., Foye, P., DeLisa, J. Spinal cord injury computer-assisted instruction for medical students. American Journal of Physical Medicine \& Rehabilitation. 2003; 82,316-319. DOI: 10.1097/01.PHM.0000056991.63927.38.

- Chittenden, E., Henry, D., Saxena, V., Loeser, H., O’Sullivan, P. Transitional clerkship: An experiential course based on workplace learning theory. Academic Medicine 2009; 84(7):872-876.

- Cho, K., Schunn, C., Charney, D. Commenting on writing: typology and perceived helpfulness of comments from novice peer reviewers and subject matter experts. Written communication. 2006; 23, 260. DOI: 10.1177/0741088306289261

- $\quad$ Cho, K., MacArthur, C. Student revision with peer and expert reviewing. Learning and instruction. 2010; 20, 328-338. DOI:10.1016/j.learninstruc.2009.08.006

- Cobb, K., Billings, D., Mays, R., Canty-Mitchell, J. Peer review of teaching in Web-based courses in nursing. Nurse educator 2001; 26(6), 274-279

- Collis, B., Margaryan, A. Applying activity theory to computer-supported collaborative learning and workbased activities in corporate settings. Educational Technology Research \& Development. 2004; 52(4), 1042-1629.

- De Wever, B., Van Winckel, M., Valcke, M. Discussing patient management online: The impact of roles on knowledge construction for students interning at the pediatric ward. Advances in Health Sciences Education. 2006(a); 13(1), 25-42. DOI: 10.1007/s10459-006-9022-6

- De Wever B, Schellens, T., Valcke M. Van Keer, H. Content analysis schemes to analyze transcripts of online asynchronous discussion groups: A review. Computers \& Education 2006(b); 46,6-28. DOI: 10.1016/j.compedu.2005.04.005

- De Wever, B. The impact of structuring tools on knowledge construction in asynchronous discussion groups, doctoral dissertation. 2006(c). University of Gent, Belgium.

- Dewiyanti, S. Learning together: a positive experience. The effect of reflection on group processes in an asynchronous computer-supported collaborative learning environment. Ph.D.-dissertation. 2005. Datawyse Maastricht. ISBN: 90-3582251-X

- Dillenbourg, P., Järvelä, S., Fischer, F. The evolution of research on computer-supported collaborative learning. From design to orchestration. In: Ludvigsen, S., de Jong, T., Lazonder, A., Barnes, S. (ed) Technology-enhanced learning: principles and products. 2009. Springer Science \& Business Media B.V. DOI: 10.1007/978-1-4020-9827-7_1

- Du J., Zhang, K., Olinzock, A., Adams, J. Graduate Students' perspectives on meaningful nature of online discussions. Journal of Interactive Learning Research. 2008; 19(1), 21-36.

- Eva, K., W., Regehr, G. Self-assesment in the health professions: a reformulation and research agenda. Academic Medicine. 2005; 80(10), 546-554. 


\section{ChAPTER 1}

- Heath, S., Higgs, J., Ambruso, D. Evidence of knowledge acquisition in a cognitive flexibility-based computer learning environment. Medical Education Online. 2008; 13,16. DOI:10.3885/meo.2008.Res00261

- Hewitt J., Scardamalia, M. Design principles for distributed knowledge building process. Educational Psychology Review. 1998; 10(1). DOI: 1040-726X/98/0300-0075\$15.00.

- Kamin, C., O'Sullivan, P., Deterding, R. Does project L.I.V.E. Case Modality impact critical thinking in PBL groups? Paper presented at the annual meeting of the American Educational Research Association, 2002. New Orleans, LA.

- Kirschner P. Using integrated electronic environments for collaborative teaching/learning. Research dialogue in learning and instruction. 2001; 2,1-9

- Kreijns, K., Kirschner, P., Jochems, W., Van Buuren, H. Measuring perceived sociability of computersupported collaborative learning environments. Computers \& Education. 2005; 49,176-192. DOI: 10.1016/j.compedu.2005.05.004

- Laurillard, D. Rethinking university teaching: a conversational framework for the effective use of learning technologies Second Edition. Routledge Falmer, Falmer Press, 2002.

- Leong, S., Baldwin, C., Adelman, A. Integrating web-based computer cases into a required clerkship: development and evaluation. Academic Medicine. 2003; 78(3), 295-301.

- $\quad$ Lillis, S., Gibbons, V., Lawrenson, R. The experience of final year medical students undertaking a general practice run with a distance education component. Rural and Remote Health. 2010; 10,1268

- Mahdizadeh, H. Student collaboration and learning. Knowledge construction and participation in an asynchronous computer-supported collaborative learning environment in higher education, doctoral dissertation, 2007. Wageningen university, the Netherlands.

- Manley, K., Titchen, A., Hardy, S. Work-based learning in the context of contemporary health care education and practice: A concept analysis. Practice development in health care. 2009; 8(2), 87-127. DOI: 10.1002/pdh.284.

- Masiello, I. , Ramberg, R., Lonka, K. Attitudes to the application of a Web-based learning system in a microbiology course. Computers \& Education. 2005; 45, 171-185. DOI:10.1016/j.compedu.2004.07.001.

- May, L., Acquaviva, K., Dorfman, A., Posey, L. Medical Student Perceptions of Self-Paced, Web-Based Electives: A Descriptive Study. American Journal of Distance Education. 2009; 23(4),212-223. DOI: 10.1080/08923640903332120

- Morrison, G., Ross, S., Kemp, J. Designing effective instruction. 2004. John Wiley \& Sons, Inc.

- Nathoo, A., Goldhoff, P., Quattrochi, J. Evaluation of an Interactive Case-based Online Network (ICON) in a Problem Based Learning Environment Advances in Health Sciences Education. 2005; 10,215-230. DOI 10.1007/s10459-005-7851-3

- $\quad$ O'Brien B., Poncelet, A. Transition to clerkship courses: Preparing students to enter the workplace. Academic Medicine 2010; 85(12), 1-8. DOI: 10.1097/ACM.0b013e3181fa2353

- Panitz, T. The motivational benefits of cooperative learning. New directions for teaching and learning. 1999; 78, Jossey-Bass Publishers

- Pena-Shaff J., Nicholls, C. Analyzing student interactions and meaning construction in computer bulletin board discussions. Computers \& Education. 2004; 42,243-265. DOI:10.1016/j.compedu.2003.08.003.

- Peska, D., Lewis,K. Uniform Instruction Using Web-Based, Asynchronous Technology in a Geographically Distributed Clinical Clerkship: Analysis of Osteopathic Medical Student Participation and Satisfaction. The Journal of the American Osteopathic Association. 2010; 110(3), 135-142.

- $\quad$ Raupach, T., Muenscher, C., Anders, S., Steinbach, R., Pukrop, T., Hege, I., Tullius, M. Web-based collaborative training of clinical reasoning: A randomized trial. 2009; 31,e431-e437. DOI: 10.1080/01421590 903095502

- $\quad$ Raupach, T., Münscher, C., Pukrop, T., Anders, S., Harendza, S. Significant increase in factual knowledge with web-assisted problem-based learning as part of an undergraduate cardio-respiratory curriculum. Advances in Health Science Education. 2010; 15,349-356. DOI: 10.1007/s10459-009-9201-3

- Scardamalia, M., Bereiter, C. Computer support for knowledge-building communities. The Journal of the Learning Sciences. 1994; 3(3), 265-283. 
- Schellens, T. Valcke, M. Fostering knowledge construction in university students through asynchronous discussion groups. Computers \& Education. 2006; 46, 349-370. DOI: 10.1016/j.compedu.2004.07.010

- Schilling, K., Wiecha, J., Polineni, D., Khalil, S. An interactive web-based curriculum on evidence-based medicine: design and effectiveness. Family Medicine. 2006; 38(2),126-132.

- Servais E., LaMorte, W., Agarwal, S., Moschetti, W., Malliputti, S., Moulton, S. Teaching surgical decisionmaking: An interactive, web-based approach. Journal of surgical research. 2006; 134,102-106. DOI:10.1016/j.jss.2005.11.583

- Shah,I., Walters, M., McKillop, J.. Acute medicine teaching in an undergraduate medical curriculum: a blended learning approach. Emergency Medicine Journal. 2008; 25,354-357. DOI:10.1136/emj.2007. 053082

- $\quad$ Singh, D. Boudville, N., Corderoy, R., Ralston, S., Tait, C. Impact on the dermatology educational experience of medical students with the introduction of online teaching support modules to help address the reduction in clinical teaching. Australasian Journal of Dermatology. 2011; 52,264-269. DOI: 10.1111/j.1440-0960.2011.00804.x

- Spickard, A., Smithers, J., Cordray, D., Gigante, J., Wofford, J. A randomized trial of an online lecture with and without audio. Medical Education. 2004; 38,787-790. DOI:10.1046/j.1365-2929.2004.01824.x

- Stahl, G. Meaning and interpretation in collaboration. In B. Wasson, S. Ludvigsen \& U. Hoppe (ed) Designing for change in networked learning environments: Proceedings of the international conference on computer support for collaborative learning. CSCL '03, Bergen, Norway, Kluwer Publishers. 2003; 523-532.

- Steele, D., Johnson Palensky, J., Lynch, T., Lacy, N., Duffy, S.Learning preferences, computer attitudes, and student evaluation of computerised instruction. Medical Education. 2002; 36,225-232.

- $\operatorname{Str} \varnothing m s \varnothing$, H., Grøttum, P., Hofgaard, L. Changes in student approaches to learning with the introduction of computer-supported problem-based learning. Medical Education. 2004;.38,390-398. DOI:10.1046/ j.1365-2923.2004.01786.x

- Taradi, S., Dogaš, Z., Dabić, M., Perić, I. Scaling-up Undergraduate Medical Education: Enabling Virtual Mobility by Online Elective Courses. Croatian Medical Journal. 2008; 49,344-351. DOI:10.3325/cmj. 2008.3.344

- Taradi, S., Taradi, M. Expanding the traditional physiology class with asynchronous online discussions and collaborative projects. Advances in Physiology Education 2004; 28,73-78. DOI:10.1152/advan.00017.2003

- Topping, K. Peer assessment between students in colleges and universities. Review of Educational Research. 1998; 68(3),249-276.

- Van Amelsfoort, M. A space for debate. How diagrams support collaborative argumentation-based learning. Ph.D.-dissertation. 2006. PrintPartners Ipskamp, Enschede.

- $\quad$ Van der Meijden, H. Knowledge construction through CSCL: Student elaborations in synchronous, asynchronous and 3-D learning environments. 2005. Drukkerij Tamminga, Duiven, The Netherlands. ISBN10:9090197184.

- Vedder, P. Cooperative learning: A study on processes and effects of cooperation between primary school children. 1985. Groningen University, The Netherlands.

- Veerman, A. Computer-supported collaborative learning through argumentation. Doctoral dissertation, 2000. University of Utrecht, the Netherlands.

- Veldhuis-Diermanse, A. CSCLearning? Participation, learning activities and knowledge construction in computer-supported collaborative learning in higher education, Doctoral dissertation, 2002. Wageningen University, the Netherlands.

- Wang, A., Newlin, M. Characteristics of students who enroll and succeed in psychology web-based classes. Journal of educational psychology. 2000; 92(1), 137-143. DOI: 10.1037//0022-0663.92.1.137.

- Weinberger, A., Ertl, B., Fischer, F., Mandl, H. Epistemic and social scripts in computer-supported collaborative learning. Instructional science, springer Verlag (Germany). 2005; 33(1),1-30. DOI:10-1007/s11251004-2322-4.

- Wiecha, J., Chetty, V., Pollard, T., Shaw, P. Web-based Versus Face-to-Face Learning of Diabetes Management: The Results of a Comparative Trial of Educational Methods. Family Medicine. 2006; 38(9),647-52. 


\section{CHAPTER 1}

- Williams, C., Aubin, S., Harkin, P., Cottrell, D. A randomized, controlled, single-blind trial of teaching provided by a computer-based multimedia package versus lecture. Medical Education. 2001; 35(35),847-854. 


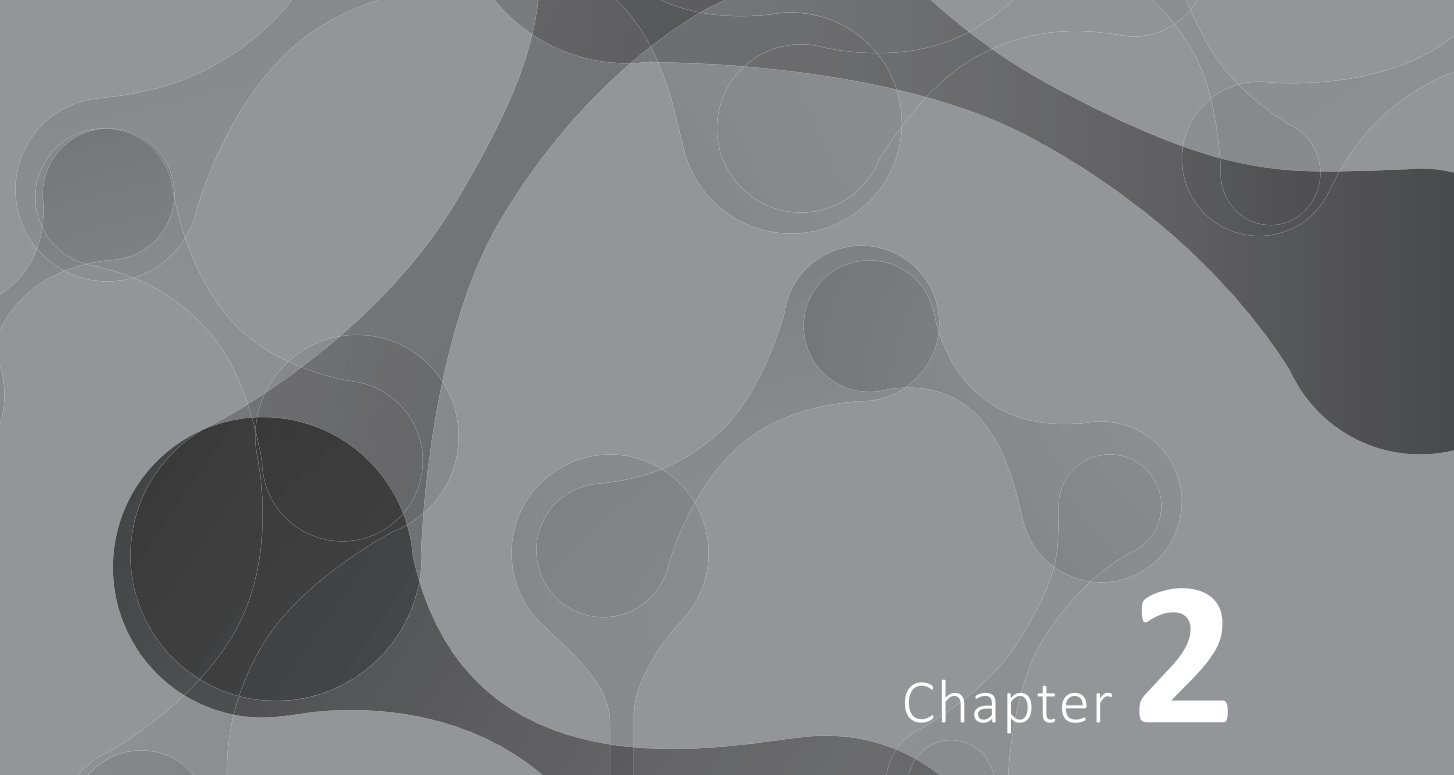

Clinical clerkship students' experiences on peer feedback of a task by a computersupported collaborative learning environment.

Published as: Willem J. M. Koops, Cees P. M. van der Vleuten, Bas A. de Leng,

S. Guid Oei, Luc H.E.H. Snoeckx.

Computer-supported collaborative learning in the medical workplace: Students' experiences on formative peer feedback of a critical appraisal of a topic paper.

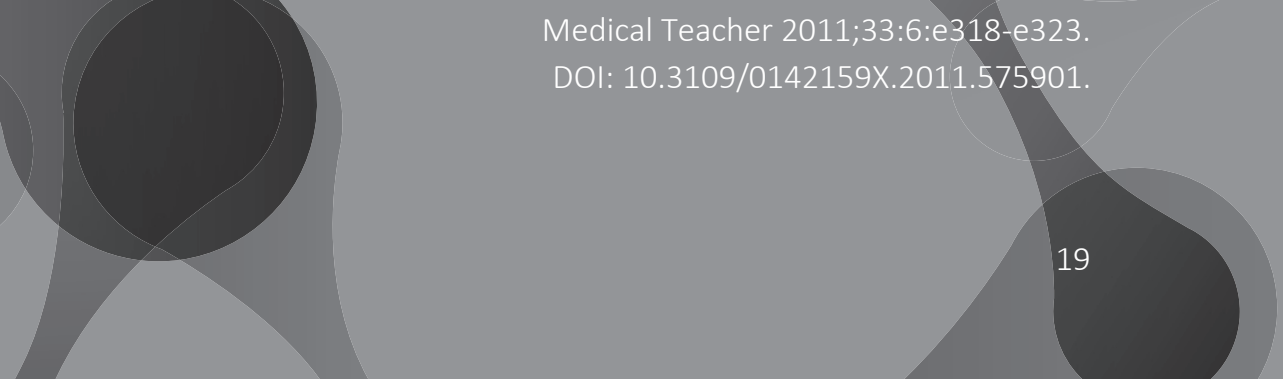




\section{ABSTRACT}

Background: Medical workplace learning consists largely of individual activities, since workplace settings do not lend themselves readily to group learning. A computersupported collaborative learning environment (CSCL) could enable learners at different workplace locations to discuss personal clinical experiences at a distance to enhance learning.

Objective: To explore whether a CSCL enabled structured asynchronous discussion forum on an authentic task has additional value for learning in the medical workplace.

Methods: Between January 2008 and June 2010, we conducted an exploratory evaluation study among senior medical students that were engaged in clinical electives. Students wrote a Critical Appraisal of a Topic paper about a clinical problem they had encountered. and discussed it in discipline homogeneous subgroups on an asynchronous forum in a CSCL environment. A mixed method design was used to explore students' perceptions of the CSCL arrangement with respect to their preparation and participation, the design and knowledge gains. We analyzed the messages recorded during the discussions to investigate which types of interactions occurred.

Results: Students perceived knowledge improvement of their papers. The discussions were mostly task-focused. The students considered an instruction session and a manual necessary to prepare for an asynchronous discussion forum in a CSCL environment. A high amount of sent messages and a high activity in discussion seems to influence scores on perceptions: 'participation' and 'knowledge gain' positively.

Conclusion: An asynchronous discussion forum in a CSCL environment appears to offer a suitable environment for peers to provide formative feedback on a Critical Appraisal of a Topic paper during workplace learning. The CSCL environment enabled students to collaborate in an asynchronous discussion forum, which positively influenced their learning. 


\section{INTRODUCTION}

For medical students, learning in the workplace is primarily an individual activity. For these students, work-based learning might nevertheless benefit from collaborative learning, which has been shown to stimulate critical thinking, deeper-level learning and shared understanding, thereby fostering active knowledge construction (Kreijns et al. 2005; Dewiyanti 2005; Van der Meijden 2005). The logistical problem of organizing collaborative learning activities for students dispersed over different training locations might, at least partly, be resolved by the use of computers to virtually connect learners and facilitate collaborative learning at a distance. This can be achieved by an electronic Learning Management System (LMS) using an asynchronous discussion forum in a Computer Supported Collaborative Learning (CSCL) environment which supports different formats for distance learning. Studies of CSCL applications in medical classroom settings have demonstrated quite good instructional effectiveness (Walker et al. 1998; Panikkar et al. 1998; Levin et al. 1998; Devit et al. 1999), but comparisons with traditional classroom formats have thrown the added value of $\mathrm{CSCL}$ arrangements into doubt (Lieberman et al. 2002; Duque et al. 2006; Evans et al. 2008; Smith et al. 2007). CSCL arrangements in workplace learning might have additional value by enabling students to share clinical experiences, and use these experiences as a starting point for deep learning. There is, however, a paucity of research evidence about the use of a discussion forum in a CSCL in workplace learning in medical education. One study demonstrated knowledge improvement when an asynchronous discussion forum in a CSCL environment was used to enable students to solve a theoretical clinical case in a controlled clinical workplace environment (De Wever et al. 2006), but essentially, we know very little about the effectiveness of an asynchronous discussion forum in a CSCL environment. We therefore conducted an exploratory evaluation study using a mixed method design to explore whether or not an asynchronous discussion forum in a CSCL environment adds value by facilitating collaborative learning from clinical experiences in the workplace. We sought students' perceptions of the usefulness of a CSCL arrangement designed specifically for this study and measured students' interactions and activities during CSCL enabled discussions.

We were interested in answering the following research questions:

- How do students perceive the instructional quality of the CSCL arrangement, particularly with regard to preparation for, participation in, the design of and knowledge gains due to the CSCL arrangement?

- How do students interact and what activities do they engage in, during a structured discussion of an authentic task in the CSCL arrangement? 


\section{METHODS}

\section{Participants}

The study was conducted between January 2008 and June 2008, and between January 2010 and June 2010 in one teaching hospital (Maxima Medical Center in Veldhoven, the Netherlands) on medical students in the last year of the six year undergraduate medical curriculum of Maastricht University, which consists of two eighteen-week electives. For this study, thirty-five students were invited, whereas twenty-seven students agreed to participate. The participants received informed consent before the start of the study and were free to withdraw their cooperation at any time. Participants were allocated to homogeneous subgroups of three students, based upon the discipline of their elective.

As a general part of the elective, students are required to write a Critical Appraisal of a Topic (CAT) paper about a self-selected clinical problem they have encountered during the elective. The CAT paper should be written in a structured way, by presenting research evidence, etiology, diagnosis, prognosis, management strategy and follow-up in relation to the clinical problem (Sauvé et al. 1995; Parkes et al. 2009). In present study, it was the first time students discussed their CAT papers in an asynchronous discussion forum in CSCL environment. Discussion took place in homogeneous subgroups of three students on electives in the same discipline.

\section{The CSCL arrangement}

DOKEOS, an open source LMS (www.dokeos.com) was used as a CSCL environment which can create online learning communities and enables delivery of instructional resources, communication and collaboration. The CSCL arrangement consisted of four consecutive phases. Phase 1: the participating students attended a face to face session in which they were instructed about the CAT assignment and the use of DOKEOS. To enable the subgroups to familiarize themselves with the asynchronous discussion forum in a CSCL environment, all students were provided with a manual, a time schedule for practice sessions for each subgroup and a pass-word and log-in code to access DOKEOS. The subgroup members were asked to schedule a practice session immediately after the instruction session. Phase 2: each student wrote a CAT paper and uploaded it to a 'drop-box' on DOKEOS. Phase 3: the subgroups discussed the CAT papers written by the three group members on the asynchronous discussion forum of DOKEOS. The discussion was structured in three prescribed steps: (1) discuss the strengths and weaknesses of the process of literature search; (2) discuss the strengths and weaknesses in the design and the execution of the research used to solve the clinical problem and, (3) evaluate the quality and discuss the amount of evidence in the research used to solve the clinical problem. 
The subgroups had to complete their discussions of the CAT papers within a two week period. It was up to the author of the paper to decide when the paper had been discussed properly. Phase 4: the students could revise their papers.

\section{Study design}

We used a mixed method study design to explore students' perceptions of the educational value of the CSCL arrangement. The students were asked to rate questionnaire items on a five-point Likert scale (1=absolutely disagree; 5 =absolutely agree) and take part in a semi-structured interview. Each interview lasted thirty till forty-five minutes and was recorded by an electronic recording device. The questionnaire and the interview addressed the same four outcome measures in relation to the CSCL arrangement: 'Preparation', 'Participation', 'Design' and 'Knowledge gain'. We used SPSS 16.0 to calculate descriptive statistics (mean, SD) for the questionnaire per subgroup, and the interviews were qualitatively analyzed by the researcher (Baarda et al., 2001).

In order to address the second research question 'How do students interact and what activities do they engage in during discussions enabled by the CSCL arrangement?, we analyzed the discussion messages that had been filed automatically by DOKEOS. We counted the overall number of messages, and the percentages of messages per subgroup. To find out how students interact, we assigned the messages to one of the following categories: 'Message to the author of the CAT paper', 'Reply message from author to discussant' and 'Message between the two discussants'. To find out in what activities students engage, we assigned each message to one of the seven categories of the Rainbow system for collaborative problem solving activities in CSCL forum discussions (Baker et al. 2007): outside activity; social relation; interaction management; task management; giving opinion; giving argumentation and broadening/deepening. The Rainbow system is designed to measure the extent to which students are engaged in interaction. For each category and for each subgroup we calculated the percentage of activities.

\section{RESULTS}

In this section the results on the outcome measures 'Preparation', 'Participation', 'Design' and 'Knowledge gain' are described. In every outcome measure the questionnaire score is described first and then all interview results are described. Every student participating in present study returned the questionnaire and was interviewed. Further on, students' interactions and activities during the CSCL forum discussion are described and combined with students perceptions. 
Students' perceptions of the quality of preparation for participating in the CSCL arrangement

Table 1 shows that the quality of their preparation for the CSCL arrangement was rated positively by the students (mean $3.6, S D \pm 0.48$ ). The interviews showed that students considered the instruction session helpful to familiarize them with the CAT task. The students did not make use of the offered opportunity to practice working in the asynchronous discussion forum in the CSCL environment. The instruction manual was considered useful and used to look up the internet address, review the assignment, and navigate DOKEOS. It is interesting to notice that students said they appreciated the instruction session and used the manual, but did not use the opportunity to practice with the CSCL arrangement.

Students' perceptions of their participation in the CSCL arrangement.

Students' participation in the CSCL arrangement consisted of engaging in forum discussions about their CAT papers by posting opinions, comments and feedback. The questionnaire score in relation to participation was $3.8( \pm 0.42)$ (Table 1$)$. The students indicated that the CAT papers were discussed adequately during the forum discussions. Students also indicated that participation was time consuming and added to their work load during the elective. Although it was not obligatory for students to write and discuss the CAT paper, the students felt that participation in the CSCL arrangements had a positive effect on their learning. The students considered two weeks an acceptable period for the forum discussion. It seems quite surprising that students evaluated their participation positively despite the time pressure and additional work load.

\section{Students' perceptions of the CSCL design}

Students rated the quality of the CSCL environment $3.7( \pm 0.47)$ on a five-point scale (Table 1). They thought that the lay-out of DOKEOS was clear and the tools were user friendly. They appreciated having time to think about their contribution to the discussion before posting a message. They also thought the asynchronous discussion forum was arranged and structured conveniently, and was appropriate for the CSCL arrangement and the specific CAT task. The students did not think that the discussion, as an extra element of the CAT task, interfered with other tasks during their elective. 


\section{Students' perceived knowledge gains after participating in the CSCL arrangement}

The students rated perceived knowledge gain as $3.6( \pm 0.49)$ (Table 1$)$. They thought participating in the CSCL arrangement had improved their knowledge. Students reported gains in knowledge with regard to scientific reasoning as a result of analyzing a clinical problem, generating search criteria, executing an appropriate search strategy and using databases for literature search. Students said they had learned to evaluate and critically appraise a research article with regard to: journal impact factor, study population and sample, selection criteria, statistics, epidemiology and conclusions. The students also remarked that the asynchronous discussion forum led to further knowledge gains in medical content knowledge which they needed to solve the clinical problem. After the discussion students revised their CAT paper with respect to both content and structure. In summary, students reported knowledge gains and improvement of their CAT paper as a result of an asynchronous discussion forum in the CSCL environment.

Table 1 Mean scores $( \pm S D)$ on the four outcome measures of students' perceptions of instructional quality of the CSCL arrangement on a 5 point Likert scale ( 1 =absolutely disagree; $5=$ absolutely agree).

\begin{tabular}{lllll}
\hline & $\begin{array}{l}\text { Preparation } \\
\text { mean (SD) }\end{array}$ & $\begin{array}{l}\text { Participation } \\
\text { mean (SD) }\end{array}$ & $\begin{array}{l}\text { Design } \\
\text { mean }(S D)\end{array}$ & $\begin{array}{l}\text { Knowledge gain } \\
\text { mean }(S D)\end{array}$ \\
\hline Subgroup 1 & $3.2( \pm 0.42)$ & $4.2( \pm 0.08)$ & $3.9( \pm 0.22)$ & $3.9( \pm 0.23)$ \\
Subgroup 2 & $3.1( \pm 0.19)$ & $3.9( \pm 0.14)$ & $3.4( \pm 0.29)$ & $3.7( \pm 0.29)$ \\
Subgroup 3 & $3.6( \pm 0.35)$ & $3.9( \pm 0.46)$ & $4.0( \pm 0.70)$ & $3.8( \pm 0.39)$ \\
Subgroup 4 & $3.8( \pm 0.73)$ & $3.5( \pm 0.30)$ & $4.0( \pm 0.30)$ & $3.6( \pm 0.48)$ \\
Subgroup 5 & $3.8( \pm 0.00)$ & $4.0( \pm 0.30)$ & $4.4( \pm 0.00)$ & $4.0( \pm 0.29)$ \\
Subgroup 6 & $3.7( \pm 0.94)$ & $3.8( \pm 0.71)$ & $4.1( \pm 0.10)$ & $3.7( \pm 0.47)$ \\
Subgroup 7 & $3.5( \pm 0.17)$ & $3.6( \pm 0.30)$ & $4.0( \pm 0.22)$ & $3.8( \pm 0.23)$ \\
Subgroup 8 & $3.6( \pm 0.67)$ & $3.8( \pm 0.46)$ & $3.4( \pm 0.25)$ & $3.3( \pm 0.22)$ \\
Subgroup 9 & $3.3( \pm 0.17)$ & $3.9( \pm 0.25)$ & $3.8( \pm 0.08)$ & $3.5( \pm 0.55)$ \\
Mean & $3.6( \pm 0.48)$ & $3.8( \pm 0.42)$ & $3.7( \pm 0.47)$ & $3.6( \pm 0.49)$
\end{tabular}

Students' interactions and activities during the asynchronous discussion forum

Students' interactions as recorded in DOKEOS consisted of 316 messages (table 2), with an average of 35 messages per subgroup. The average number of messages posted during the discussion of one CAT paper was eleven to twelve. Individual students posted three to four messages per discussion. Classification of the messages showed, on the average, that $60 \%$ of all messages were sent to the author of the paper under discussion, $37.1 \%$ were replies by the author, and $2.9 \%$ concerned messages between the two discussants. Remarkable is that the more messages were sent, the more discussion took place between the three students of the subgroup. 
Table 2 The number of messages sent by participants, and the percentages of sent messages categorized in: Messages sent to author; Reply messages from author; Messages between discussants, for each subgroup and in total.

\begin{tabular}{lllll}
\hline & $\begin{array}{l}\text { Number of } \\
\text { messages }\end{array}$ & $\begin{array}{l}\text { Messages sent } \\
\text { to author } \\
(\%)\end{array}$ & $\begin{array}{l}\text { Reply messages } \\
\text { from author } \\
(\%)\end{array}$ & $\begin{array}{l}\text { Messages between } \\
\text { discussants } \\
(\%)\end{array}$ \\
\hline Subgroup 1 & 41 & 53.6 & 41.5 & 4.9 \\
Subgroup 2 & 68 & 67.6 & 30.9 & 1.5 \\
Subgroup 3 & 53 & 64.1 & 32.1 & 3.8 \\
Subgroup 4 & 20 & 90.0 & 10.0 & 0.0 \\
Subgroup 5 & 52 & 57.7 & 36.5 & 5.8 \\
Subgroup 6 & 14 & 35.7 & 64.3 & 0.0 \\
Subgroup 7 & 24 & 54.1 & 41.7 & 4.2 \\
Subgroup 8 & 10 & 40.0 & 60.0 & 0.0 \\
Subgroup 9 & 34 & 50.0 & 47.1 & 2.9 \\
Total & 316 & 60.0 & 37.1 & 2.9 \\
\hline
\end{tabular}

The categories of activities during the discussions are shown in Table 3. Task-focused activities (categories 4, 5, 6 and 7) accounted for $81.9 \%$ of all subgroup activities, with $80.3 \%$ of the activities being discussion activities (categories 5, 6 and 7). Non-taskfocused activities (categories 2 and 3) accounted for $13.5 \%$ and outside activities (category 1 ) for $4.4 \%$ of the activities. Subgroup 2 , in which the most messages were sent, showed discussion activity only. Subgroups 4, 6, 7, 8 and 9, in which a low number of messages were sent, showed no broaden and deepen activities. 
CLINICAL CLERKSHIP STUDENTS' EXPERIENCES ON PEER FEEDBACK

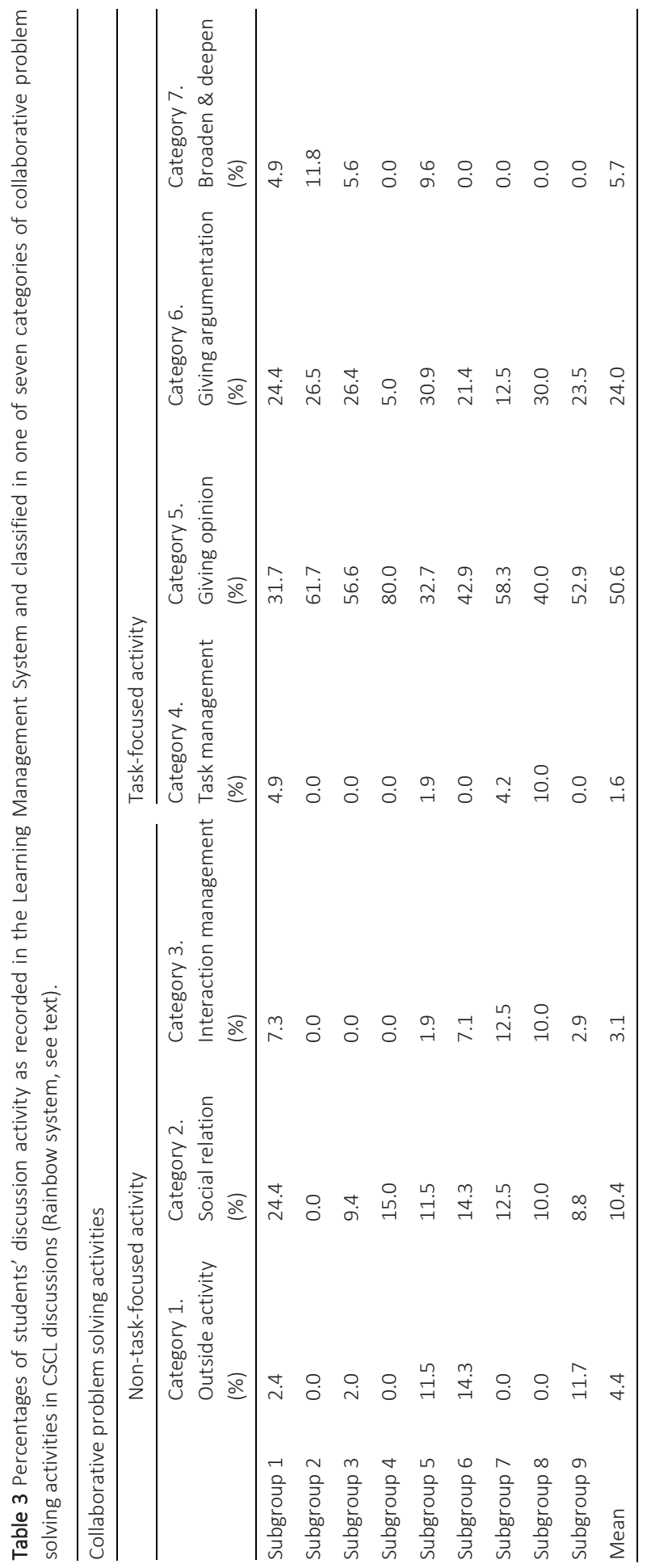




\section{Students' perception combined with interaction and activity during the asynchronous discussion forum}

For every subgroup, students' perceptions were combined with the number of messages and with students' activity on the forum. On students' perceptions: 'participation' and 'knowledge gain' subgroups 1 and 5 showed high scores, with a high number of messages sent and replied by all students. Furthermore, these subgroups showed discussion activity in every category. Although, discussion activity was merely task-focused, where 'giving opinion' occurred most frequently, with lower frequencies for 'giving arguments' and 'broaden and deepen'. Subgroups with a low score on perceptions: 'participation' and 'knowledge gain' showed no broaden \& deepen activities. Other students' perceptions, 'design' and 'preparation' showed no clear influence on sent messages and discussion activities.

\section{DISCUSSION}

We explored whether or not a CSCL arrangement offered added value to the learning of students from their clinical experiences in the medical workplace by conducting a mixed-method design.

The students gave a positive judgement of their preparation for participation in the $\mathrm{CSCL}$ arrangement by an instruction session and a manual. They said it helped them get used to the CSCL arrangement and tasks, and to execute the tasks properly. This can be confirmed by other studies (Schellens et al. 2005; De Wever et al. 2006; Komoroski 1998) which have measured whether or not preparation for an asynchronous discussion forum in a CSCL environment influenced task execution. These studies showed that it saves time to prepare participants by informing them of the design and technical aspects of the asynchronous discussion forum in a CSCL environment, such as access, use of tools and tips and tricks on how the forum works, because preparation can solve many questions and problems before students actually engage in the discussion tasks.

Students gave high ratings on their participation in the discussion forum. Considering students thought participation required considerable effort in terms of time and work, and even though the task was not obligatory it is remarkable that students showed quite high scores on participation in the discussion. This may be associated with the fact that the subgroups were homogeneous as to specialty as well as to the tight time schedule.

Students' perceptions of the design of the asynchronous discussion forum in a CSCL arrangement were positive. This is encouraging in light of findings that students' positive perceptions can mediate the meaningfulness and the effectiveness of classroom learning arrangements both traditional and CSCL ones (Laurillard 2002; Morrison et al. 2004; Driscoll 2005; Dewiyanti 2005). 
The present study showed that structuring students' tasks and the forum discussion may be important to achieve meaningful and effective learning.

Students reported knowledge gains after interacting in the CSCL arrangement, with improvements in medical content knowledge as well as in scientific reasoning. According to students, this resulted in improvements in both content and structure of their CAT papers. Knowledge gains were also found in studies of the instructional effectiveness of CSCL in classroom settings (Walker et al. 1998; Panikkar et al. 1998; Levin et al. 1998; Devit et al. 1999). Like our study, these studies only reported students' selfperceived knowledge gains.

The average number of messages on the discussion forum was considered to be sustainable by the researchers. However, there is no research based standard available for a sustainable number of messages when students interacting. According to the messages sent, discussion was merely focused on the author and activity was highly taskfocused. However, on subgroup level, scores were scattered. When students' perceptions were combined with the sent and replied messages during discussion, and with students' activity in discussion, students' scores on 'participation' and on 'knowledge gain' showed influence on the discussion. Subgroups with high ratings on participation showed a discussion between all subgroup members and all subgroup members were highly active in discussion. Since the main purpose of the $\mathrm{CSCL}$ arrangement was to enable students to share, discuss and elaborate on their personal experiences as a way to promote effective learning (Laurillard 2002), these positive ratings are an important indication of the effectiveness of the CSCL arrangement.

One of the limitations of this study is that the outcomes, apart from the analysis of the discussions, were solely based on students' perceptions. Further studies will be needed to obtain evidence from additional sources to confirm the findings, such as evidence from knowledge tests that students' knowledge actually improved after their participation in an asynchronous discussion forum in a CSCL environment. Furthermore, this study was conducted on one specific task, a structured discussion of a CAT paper. Critical appraisal of a topic is an important task in workplace learning, for students learn to analyze a clinical problem, which arise from their own experience, in an evidencebased manner (Sauvé et al. 1995; Parkes et al. 2009).

Another limitation is that this study was conducted in one teaching hospital. This facilitated the researcher to provide students with a proper instruction about the CSCL arrangement and allowed direct control of the LMS if students experienced problems or asked questions about the system. Due to these limitations, the results of this study may not be generalizable, to other tasks and/or other settings. Further on, it could be argued that an open forum discussion would stimulate the unrestricted debate. However, since former studies have demonstrated that a structured asynchronous discussion forum in a CSCL environment is indispensable, we finally decided to ask the students to concentrate upon three key-items of a Critical Appraisal of a Topic (Hron et al. 2000; 
Baker et al. 1997; Hirsch et al. 2004; Fischer et al. 2002). A final limitation is that no control group was included in the study.

We recommend further studies of the transfer of knowledge to be applied in different setting of the medical workplace. Research should identify knowledge transfer resulting in behavioral change of medical students to benefit patient care. Research should also examine which educational format is most suitable for which discussion task.

Furthermore, in the field of content-analysis, further research should determine the number of messages that is sustainable for a reliable outcome and examine which type of content analysis system is suitable for which educational method.

\section{CONCLUSION}

Based on the results of the present study we conclude that an asynchronous discussion forum in a CSCL environment appears to be a promising format to enable students to provide formative feedback on each other Critical Appraisal of a Topic paper. Subjectively, students expressed positive opinions about their experiences with an asynchronous discussion forum in a CSCL environment in terms of participation and knowledge gain. Analysis of the asynchronous discussions showed that students who are engaged actively in discussions, show high scores on their participation and on knowledge gain. Students subjective perception on participation and knowledge gain seems to be connected with sent messages and discussion activity. Further studies are recommended to investigate whether students' subjective positive perceptions can be confirmed by objective evidence from additional sources. 


\section{REFERENCES}

- Baarda, D., De Goede, M., Teunissen, J.. Basisboek Kwalitatief onderzoek (Basics of qualitative research). 2001. Noordhoff Uitgevers, the Netherlands. ISBN: 9001807704.

- Baker, M., Andriessen, J., Lund, K., Amelsvoort, van, M., Quignard, M. Rainbow: A framework for analyzing computer-mediated pedagogical debates. Computer-Supported Collaborative Learning. 2007; 2,315-357. DOI: 10.1007/s11412-007-9022-4.

- Baker, M., Lund, K. Promoting reflective interactions in a CSCL environment. Journal of Computer Assisted Learning. 1997; 13,175-193.

- De Wever, B., Van Winckel, M., Valcke, M. Discussing patient management online: The impact of roles on knowledge construction for students interning at the pediatric ward. Advances in Health Sciences Education. 2006; 13(1),25-42. DOI: 10.1007/s10459-006-9022-6

- Devitt, P., Palmer, E. Computer-aided learning: an overvalued educational resource ? Medical Education. 1999; 33, 136-139.

- Dewiyanti, S. Learning together: a positive experience. The effect of reflection on group processes in an asynchronous computer-supported collaborative learning environment. Ph.D.-dissertation. 2005. Datawyse Maastricht. ISBN: 90-3582251-X

- $\quad$ Driscoll, M. Psychology of learning for instruction. 2005. Pearson Allyn and Bacon. ISBN: 0205375196.

- Duque, G., Roberts, A., Hui, J., Posel, N.,Fleiszer, D., Chiu, W. From the facts to the screen: a blended model of teaching basic hospital skills to $2^{\text {nd }}$ year medical students. Medical Teacher. 2006; 28(8),729733. DOI: 10.1080/01421590601032450

- Evans, P., Suzuki, Y., Begg, M., Lam, W. Can medical students from two cultures learn effectively from a shared web-based learning environment ? Medical Education. 2008; 42,27-33. DOI:10.1111/j.13652923.2007.02901.x

- $\quad$ Fischer, F., Bruhn, J., Gräsel, C., Mandl, H. Fostering collaborative knowledge construction with visualization tools. Learning and Instruction. 2002; 12,213-232.

- Hirsch, L., Saeedi, M., Cornillon, J., Litosseliti, L. A structured dialogue tool for argumentative learning. Journal of Computer Assisted Learning. 2004; 20,72-80.

- Hron, A., Hesse, F., Cress, U., Giovis, C. Implicit and explicit dialogue structuring in virtual learning groups. British Journal of Educational Psychology. 2000; 70,53-64.

- Komoroski, E. Use of e-mail to teach residents pediatric emergency medicine. Archives of Pediatrics \& Adolescent Medicine. 1998; 152,1141-1146.

- Kreijns, K., Kirschner, P., Jochems, W., Van Buuren, H. Measuring perceived sociability of computersupported collaborative learning environments. Computers \& Education. 2005; 49,176-192. DOI: 10.1016/j.compedu.2005.05.004

- Laurillard, D. Rethinking university teaching: a conversational framework for the effective use of learning technologies Second Edition. 2002. Routledge Falmer, Falmer Press. ISBN: 0415256798.

- Levin, D, Ben-Jacob, M. Using Collaboration in Support of Distance learning. WebNet 98 World Conference of the WWW, Internet and intranet Proceedings ( $3^{\text {rd }}$ Orlando, FL, November 7-12 1998)

- Lieberman, G., Abramson, R., Volkan, K., McArdle, J. Tutor versus computer: A prospective comparison of interactive tutorial and computer-assisted instruction in radiology education. Academic Radiology. 2002; 9,40-49.

- Morrison, G., Ross, S., Kemp, J. Designing effective instruction. 2004. John Wiley \& Sons, Inc. ISBN: 0470074264.

- Panikkar, J., Draycott, T., Cook, J. The evaluation of computer-aided learning in medicine. Postgraduate Medical Journal. 1998; 74,706-708.

- Parkes J., Hyde C., Deeks J., Milne, R. Teaching critical appraisal skills in health care settings. Cochrane Database of Systematic Reviews. 2009; issue 3, art. No.: CD001270. DOI: 10.1002/14651858.CD001270. 


\section{ChAPTER 2}

- Sauvé, S., Lee, H., Meade, M., Lung, J., Farkouh, M., Cook, D., Sackett, D. The Critically Appraised Topic: A Practical Approach to Learning Critical Appraisal. Annuals of the Royal College Physicians and Surgeons of Canada. 1995; 28,396-398.

- Schellens, T. Valcke, M.. Collaborative learning in asynchronous discussion groups: What about the impact on cognitive processing? Computers in Human Behaviour. 2005; 21,957-975. DOI: 10.1016/ j.chb.2004.02.025

- Smith, S., Roberts, N., Partridge, M. Comparison of a web-based package with tutor-based methods of teaching respiratory medicine: subjective and objective evaluations. Medical Education. 2007; 7,41-49. DOI:10.1186/1472-6920-7-41

- Van der Meijden, H. Knowledge construction through CSCL: Student elaborations in synchronous, asynchronous and 3-D learning environments. 2005. Drukkerij Tamminga, Duiven, The Netherlands. ISBN10:9090197184.

- Walker J., Thomson, A., Smith, P. Maximizing the world wide web for high quality educational and clinical support to health and medical professionals in rural areas. International Journal of Medical Informatics. 1998; 50,287-291.

- Wutoh, R., Boren, S., Balas, E. E-learning: a review of internet-based continuing medical education. The journal of continuing education in the health professions. 2004; 24,20-30. 


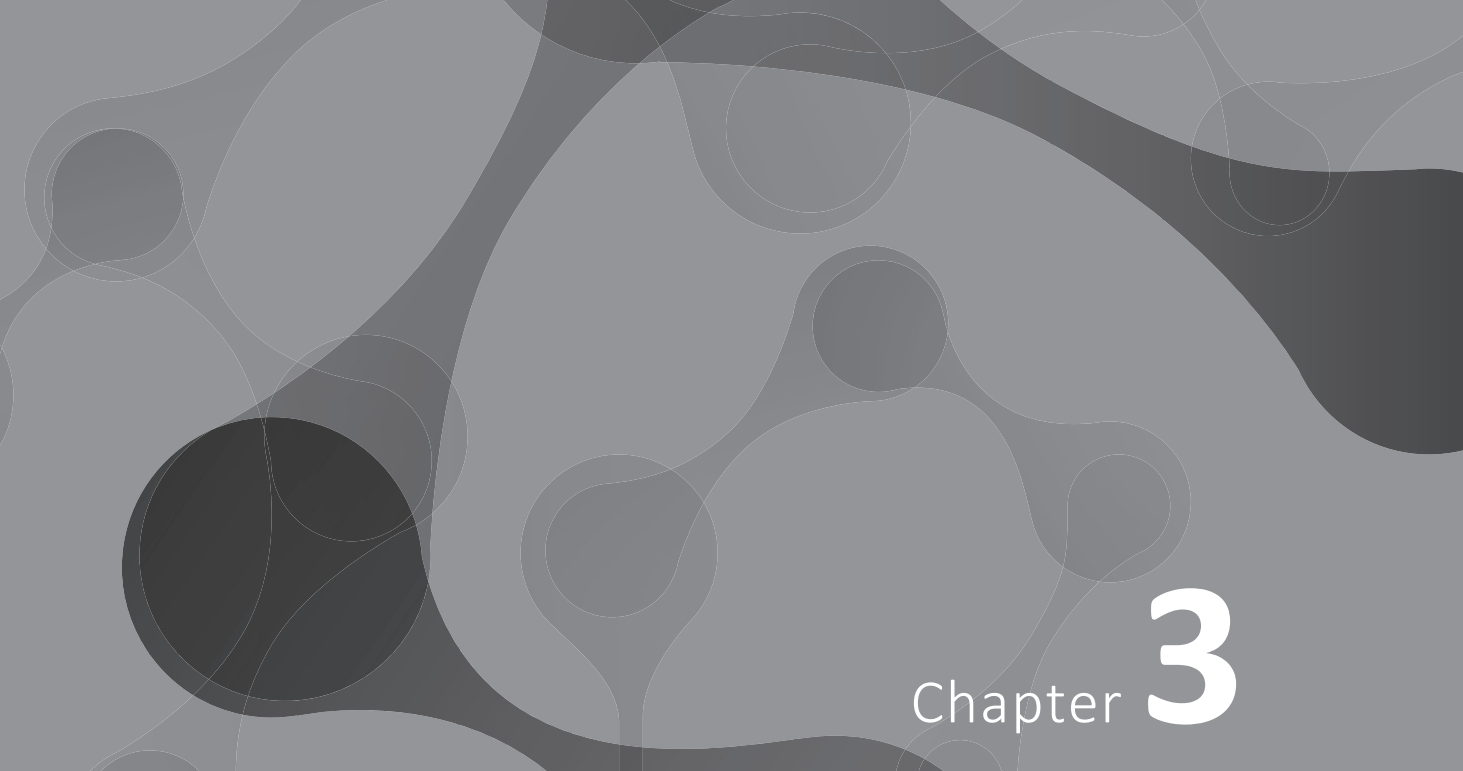

Clinical clerkship students' perceptions and the effect of knowledge construction on learning outcome by a computer-supported collaborative learning environment.

Published as: Willem J.M. Koops, Cees P.M. van der Vleuten, Bas A. de Leng, Saskia Houterman, Luc H.E.H. Snoeckx. Computer-supported Collaborative Learning at the Clinical Workplace: Students' Perceptions and the Effect of Knowledge Construction on Learning Outcome. Journal of Contemporary Medical Education 2014; 2(2): 71-78.

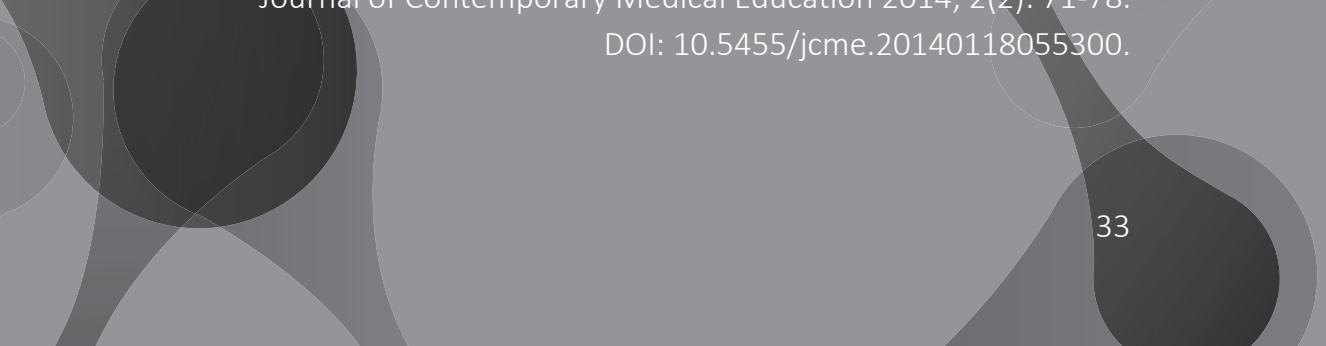




\section{ABSTRACT}

Background: Individual online learning in medical education has shown positive learning outcome. However, from a social-constructivist perspective, students are participants of a collaborative learning process. Online collaborative learning in a clinical environment can be organized by computer-supported collaborative learning (CSCL). Although it is known that student's perceptions influences their knowledge construction in CSCL arrangements, it remains unclear whether students' knowledge construction in an asynchronous discussion forum in a CSCL environment can positively influence students' learning outcome, expressed by marks given by an expert.

Objective: the purposes of present study are (1) to explore medical students' subjective perceptions on a task in an asynchronous discussion forum in a CSCL environment. (2) To explore the effect of medical students knowledge construction on knowledge improvement. (3) To explore whether medical students' learning outcome was positively improved by active knowledge construction.

Methods: Forty-four medical students were randomly assigned to either an experimental $(n=21)$ or control group $(n=23)$. Each individual student had to solve a selfselected clinical problem, written down in a pre-formatted critical appraisal paper. Students of the experimental group participated in a structured asynchronous on-line discussion on their papers. Students in the control group did not discuss their papers with peers. All students submitted their final paper for grading. Students in the experimental group were asked whether the paper was revised after discussion according to peer feedback. A questionnaire and a semi-structured interview was used to address students' perceptions on preparation, design, participation and knowledge improvement. Students' discussion postings were analyzed on content. Postings were classified in revised or unrevised paper discussions, and compared. All papers were blinded by the researcher and independently rated by two experienced staff-members. Papers were classified in control group papers, and in pre and post (revised) papers from the experimental group. Marks were compared between pre and post papers, and between papers from the control group and post papers. Students' post papers were paired with the corresponding pre papers and compared by mark.

Results: Questionnaire items showed positive students' perceptions on design, participation, and knowledge improvement. Interview items reported both positive and negative perceptions by students. Content-analysis of postings showed a significantly higher level of knowledge construction in the revised paper discussions. However, no mark differences were found between the pre and post papers, as well as between the control group papers and the post papers from the experimental group. 
Six post papers were revised by students after discussion and paired with corresponding pre papers, showing no significant differences between pairs.

Conclusion: Medical students show positive subjective perceptions on a structured asynchronous on-line discussion of their papers. Medical students revising their written task after discussion, show significantly higher active knowledge construction during an asynchronous discussion forum in a CSCL environment. Active knowledge construction of medical students during an asynchronous discussion forum in a CSCL environment is not necessarily paralleled by a significantly higher expert grading. 


\section{INTRODUCTION}

In medical education, individual online learning has a positive effect on learning outcome, for instance by online modular courses (Aronoff et al. 2010; Westendorp et al. 2002), and by online solving clinical case problems (Shokar et al. 2005; Servais et al. 2006; Leong et al. 2003; Williams et al. 2001). However, from a social-constructivist perspective, students are not to be considered as individual learners, but as participants of a collaborative learning process during which knowledge is actively constructed, and situated in realistic settings (Versloot et al. 2000; Veldhuis-Diermanse 2002; De Wever 2006a). Knowledge construction, as a component of the social-constructivist perspective, is considered as a process in which a student integrates new knowledge with their existing knowledge. Learning collaboratively, instead of individually, is regarded as essential to the learning process, fostering students' active knowledge construction by stimulating critical thinking, deeperlevel learning and shared understanding in a social manner. Collaborative knowledge construction shows more active, reflective, and socially engaged learners (VeldhuisDiermans 2002; Kreijns et al. 2005; Dewiyanti 2005; Van der Meijden 2005). Collaborative learning in a clinical environment, where medical students are spread across clinical attachments, can be organized online, by computer-supported collaborative learning (CSCL). CSCL not only involves students in a collaborative learning process, but the principles of $\mathrm{CSCL}$, such as deep-level learning, problem solving and critical thinking are also consistent with the social-constructivist perspective of learning (Scardamalia et al. 1994; Mahdizadeh 2007). Collaboration among students can be enhanced via participation on an asynchronous discussion forum. This allows students to participate at a time and on a location they prefer (De Wever 2006a) and provides them the necessary time to submit a wellconsidered reply (Stahl 2003). Students participating on a forum in a CSCL environment contribute to their knowledge construction process by externalizing and verbalizing their thoughts by writing down their opinions. Moreover, they share these thoughts in a structured way with their peers by explaining, discussing and reflecting these opinions (Veldhuis-Diermanse 2002; Van der Meijden 2005; Mahdizadeh 2007). These activities contribute to students' knowledge construction, and influences the learning process of students positively (Veldhuis-Diermanse 2002; De Wever 2006a; Van der Meijden 2005; De Wever et al. 2006b). In medical education, research reports on an asynchronous discussion forum in CSCL in a clinical workplace are few. One study on a structured asynchronous discussion forum in a CSCL environment provided evidence for a positive learning outcome on knowledge improvement by pediatric interns after solving a theoretical clinical case (De Wever et al. 2006b). In a recent explorative study on an asynchronous discussion forum in a CSCL environment (Koops et al. 2012), we found a high level of knowledge construction activities during students' learning process. Furthermore, we demonstrated that medical students scored positive perceptions on knowledge improvement and on high level of participation during discussion. These subjective perceptions seemed to be related to a high level of knowledge construction by students during discussion. 
Previous studies described that students' perceptions of their learning environment tend to guide their attitudes, behavior and modes of knowledge construction in that environment (Mahdizadeh 2007). Students' positive perceptions can mediate the meaningfulness and the effectiveness of classroom learning arrangements both traditional and CSCL ones (Dewiyanti 2005; Mahdizadeh 2007; Laurillard 2002; Morrison 2004; Driscoll 2005). However, it remains unclear whether in clinical education medical students' knowledge construction during an asynchronous discussion forum in a CSCL environment can positively influence students' learning outcome.

Therefore, the first aim of the present study was to explore medical students subjective perceptions on a task in an asynchronous discussion forum in a CSCL environment. Next, the second aim was to explore the effect of medical students knowledge construction on knowledge improvement. Finally, the third aim was to explore whether medical students' learning outcome was positively improved by active knowledge construction.

\section{METHODS}

\section{Participants and task}

This study was conducted with students during the final (third) year of the Master in Medicine education at the Faculty of Health, Medicine and Life Sciences at the Maastricht University, the Netherlands, from January until June 2009. Participating students followed an eighteen weeks elective in various clinical disciplines in nine different hospitals, eight of which were localized in the Netherlands and one in Austria. During this elective, each student had to perform a number of specific tasks, individually. One of which was the thorough investigation of a self-selected clinical problem encountered during the elective. To address this clinical problem, each individual student had to write a pre-formatted paper, a so-called Critical Appraisal of a Topic (CAT). In this task students investigate the research literature regarding etiology, diagnosis and prognosis of a disease, therapy and follow-up (Sauvé et al. 1995; Parkes et al. 2009).

\section{Study design}

Forty-four students participated in this study. They all received informed consent before the start of the study and were free to withdraw their cooperation at any time. In a controlled study design, the participants were randomly assigned to either a control group ( $n=23 ; 17$ female and 6 male students, mean age: 24 years) or an experimental group ( $n=21 ; 16$ female and 5 male students, mean age: 25 years). Randomization of participants was conducted by the principal investigator by first allocating the students' name to a number. Every individual number was put in a separate envelope. 


\section{CHAPTER 3}

An independent faculty member drew an envelope to allocate in an alternating way the containing students' number to either the experimental or control group. In both groups, students had to execute the CAT task.

The intervention in the experimental group was that, after completion of the CAT task, students participated in a structured asynchronous discussion forum of the open source CSCL environment DOKEOS (http://www.dokeos.com) to discuss their pre CAT paper. After this discussion, the students of the experimental group were allowed (but not compelled) to revise their CAT paper, as inspired by the feedback received from their peers. All students uploaded their final paper (post CAT paper) on the CSCL environment, and specifically indicated whether or not their paper was revised after discussion. Students in the control group did not participate in the asynchronous discussion forum, and submitted their CAT papers by e-mail to the principal investigator of this study (Figure 1).

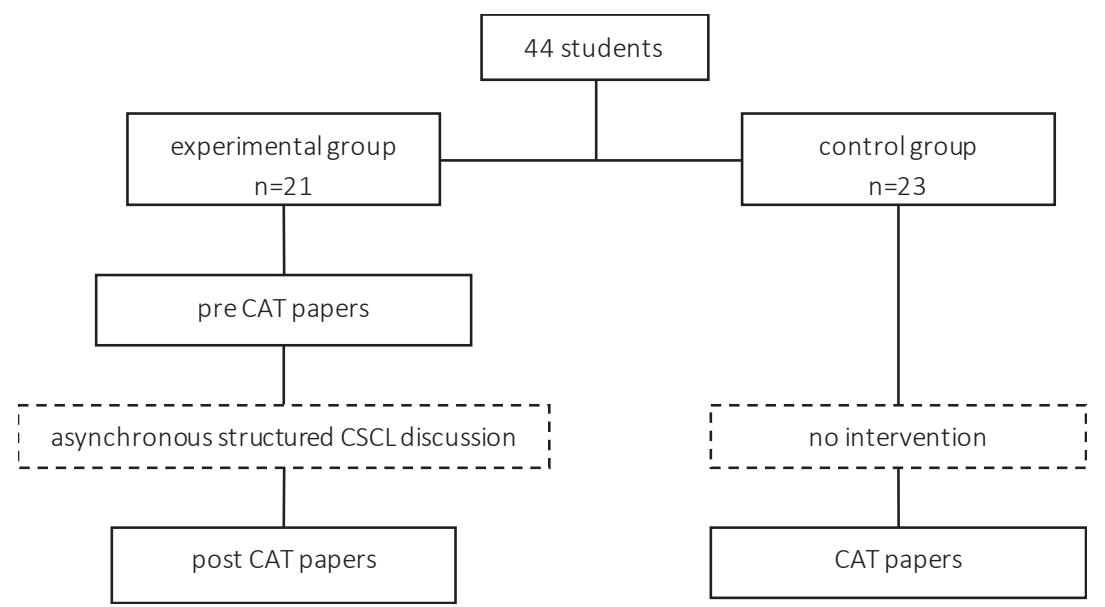

Figure 1 flow chart of present study design

In the experimental group, 7 subgroups with 3 students each were created. Each individual student uploaded his pre CAT paper to a 'drop-box' in the CSCL environment. Within each subgroup, the students critically commented their peers' CAT papers on three prescribed topics of critical appraisal, i.e.: (1) the process of literature search regarding the clinical problem, as presented in the paper; (2) the design and the execution of the cited research used to address the clinical problem and, (3) the quality, respectively the amount of evidence in the cited research used to address the clinical problem. Each prescribed topic consisted of 6 subtopics each. Students' postings were visible for the subgroup members and the principal investigator only.

To prepare students in the experimental group on their task, each student received an instruction manual via e-mail. The manual contained information about the design and use of the asynchronous discussion forum in a CSCL environment. 
According to the characteristics of an asynchronous discussion forum in a CSCL environment where students have to regulate, control and evaluate their learning process (Dillenbourg et al. 2009) the arrangements of the discussion on an individual CAT paper including the start, the sequence, and the sufficiency of the discussion was left to the group members. A two week period was allowed for the discussion of one individual paper.

\section{Measurement instruments and statistical analysis}

To address the first research aim, students' perceptions on the use of the CSCL arrangement were evaluated by using a questionnaire concentrating upon the items 'Preparation', 'Participation', 'Design', and 'Knowledge improvement'. It was considered to be important to get insight in these four items, for a proper preparation by an instruction session and a manual facilitated the use of an asynchronous discussion forum in the CSCL environment and to execute the tasks properly (De Wever 2006a; Koops et al. 2011; Schellens et al. 2005; Komoroski 1998; Veerman 2000). The extent of students' participation was considered to support students active contribution on the knowledge construction process (Veldhuis-Diermanse 2002; Koops et al. 2011). The design of the structured task and forum was measured, for positive perceptions on the design are found to contribute to achieve meaningfulness, the effectiveness of CSCL arrangements, and knowledge construction (De Wever 2006a; Dewiyanti 2005; Mahdizadeh 2007; Koops et al. 2012; Laurillard 2002; Morrison 2004; Driscoll 2005). Knowledge improvement was measured in order to find similarities between students' subjective perceptions and objective learning outcome by marks. To achieve further insight on students' questionnaire scores, it was decided to conduct a semi-structured interview as well. Students were asked to score each questionnaire item on a five-point Likert scale ( 1 =absolutely disagree; 5 =absolutely agree). Descriptive statistics (mean, \pm SD) were calculated on each of the four perception items.

The individual interviews lasted for thirty till forty-five minutes each, and were recorded with an electronic recording device. All twenty-one interviews were qualitatively analysed by a structured analysis method (Baarda et al. 2001). First, the text of ten interviews was assessed, and irrelevant information was removed. The remaining text was fragmented and labelled to one of the four items of students' perceptions. Validation of labelling was conducted by analyzing the remaining interviews following the analysis method as described above.

To address the second research aim, students' level of knowledge construction during discussion was operationalized by content-analysis of students' activity during discussion, defined by the postings that student sent each other during the discussion on the forum. Content-analysis of these postings was performed according to the validated Rainbow system (Baker et al. 2007). 


\section{CHAPTER 3}

Accordingly, seven categories of communicative interaction can be distinguished, which are then grouped into three collaborative problem solving activities, i.e., outside activity, non-task-focused activity or task-focused activity. Within the group of task-focused activity, the categories 5, 6 and 7 are considered to reflect the highest levels of knowledge construction, respectively (Table 1 ).

Table 1 Rainbow system for content analysis; activity, category, and category definitions

\begin{tabular}{|c|c|c|}
\hline \multicolumn{3}{|c|}{ Content analysis system (Baker et al. 2007 ) } \\
\hline $\begin{array}{l}\text { Collaborative } \\
\text { problem solving activity }\end{array}$ & $\begin{array}{l}\text { Category of } \\
\text { communicative interaction }\end{array}$ & Definition \\
\hline Outside & 1. Outside & $\begin{array}{l}\text { Any interaction that is not concerned with interacting in } \\
\text { order to carry out the defined task, e.g., talk about last } \\
\text { night's party. }\end{array}$ \\
\hline \multirow[t]{2}{*}{ Non-task-focused } & 2. Social relation & $\begin{array}{l}\text { Interaction concerned with managing the students' } \\
\text { social relations with respect to the task, e.g., greeting, } \\
\text { leave-taking, politeness. }\end{array}$ \\
\hline & 3. Interaction management & $\begin{array}{l}\text { Interaction concerned with managing the interaction } \\
\text { itself, e.g., coordination (who will speak and who will } \\
\text { not), establishing contact, topic shifting. }\end{array}$ \\
\hline \multirow[t]{4}{*}{ Task-focused } & 4. Task management & $\begin{array}{l}\text { Management of the progression of the task itself, e.g., } \\
\text { planning what is to be discussed, establishing whether } \\
\text { problem is solved or not. }\end{array}$ \\
\hline & 5. Opinions & $\begin{array}{l}\text { Interaction concerned with expressing opinions about } \\
\text { the topic of discussion, e.g., beliefs, acceptances. }\end{array}$ \\
\hline & 6. Argumentation & $\begin{array}{l}\text { Expression of (counter-) arguments directly related to a } \\
\text { thesis, or theses themselves, e.g., requests for } \\
\text { justification }\end{array}$ \\
\hline & 7. Broaden and deepen & $\begin{array}{l}\text { Interaction concerned with (counter-)arguments linked } \\
\text { to (counter-) arguments, argumentative relations and } \\
\text { the meaning of arguments themselves, e.g., } \\
\text { elaborations of arguments, definition. }\end{array}$ \\
\hline
\end{tabular}

All blinded postings were analyzed by the principal investigator. Individual postings were considered as a unit of analysis, and labelled to one of the seven categories of communicative interaction. When an analysis unit contained multiple categories of communicative interaction, a posting was split into different units of analysis (Schellens et al 2005; Rourke et al. 2001). Furthermore, to address students' knowledge improvement labelled units were classified as belonging to revised or unrevised CAT papers. For every category of communicative interaction, the number of analysis units was statistically compared between revised and unrevised papers using a Mann-Whitney $U$ test for independent samples. 
To address the third research aim, students learning outcome was operationalized by students' paper marks. Pre and post CAT papers from the experimental group and CAT papers from the control group were blinded by the principal investigator first.

Then all papers were sent to two experts for independent grading. This grading was conducted according to a CAT scoring list, commonly used in the medical curriculum of the Maastricht University. In more detail, this scoring list consists of eighteen subtopics addressing the three prescribed topics of critical appraisal, described earlier in the study design section. Grading was conducted on a scale of 1 to 10 (where 10 is the highest score). Descriptive statistics (mean, $\pm \mathrm{SD}$ ) were calculated on the overall CAT paper marks, as well as on the three critical appraisal topics. In order to determine the rating consistency of paper marks, an inter-rater Kappa reliability analysis was performed on the overall mean paper marks given by the two experts. Furthermore, the mean overall and topic marks were statistically compared between the pre and post CAT papers of the experimental group, and between the post CAT papers of the experimental group and the CAT papers from the control group, using an Independent-Samples T-test. Finally, the mean overall marks of revised post CAT papers were compared with the corresponding pre CAT papers, using a paired-Samples T test.

\section{RESULTS}

Twenty-three CAT papers were submitted by students from the control group. In the experimental group, twenty-one papers (pre CAT) were uploaded before discussion, and twenty-one papers (post CAT) were uploaded after the discussion. From these post CAT papers, six papers were revised and fifteen were not revised.

\section{Students' perceptions}

\section{Questionnaire results}

Nineteen (91\%) students from the experimental group expressed their perceptions by returning the questionnaire. The questionnaire results are presented in Figure 2.

Students reported positive perception scores on the questionnaire items 'Participation' (mean: $3.7 ; \pm$ SD: 0.6), 'Design' (mean 3.6; \pm SD 0.5), and 'Knowledge improvement' (mean 3.5; \pm SD 0.5) On the item 'Preparation' students score rather low (mean: 2.8; $\pm S D: 0.5)$. 


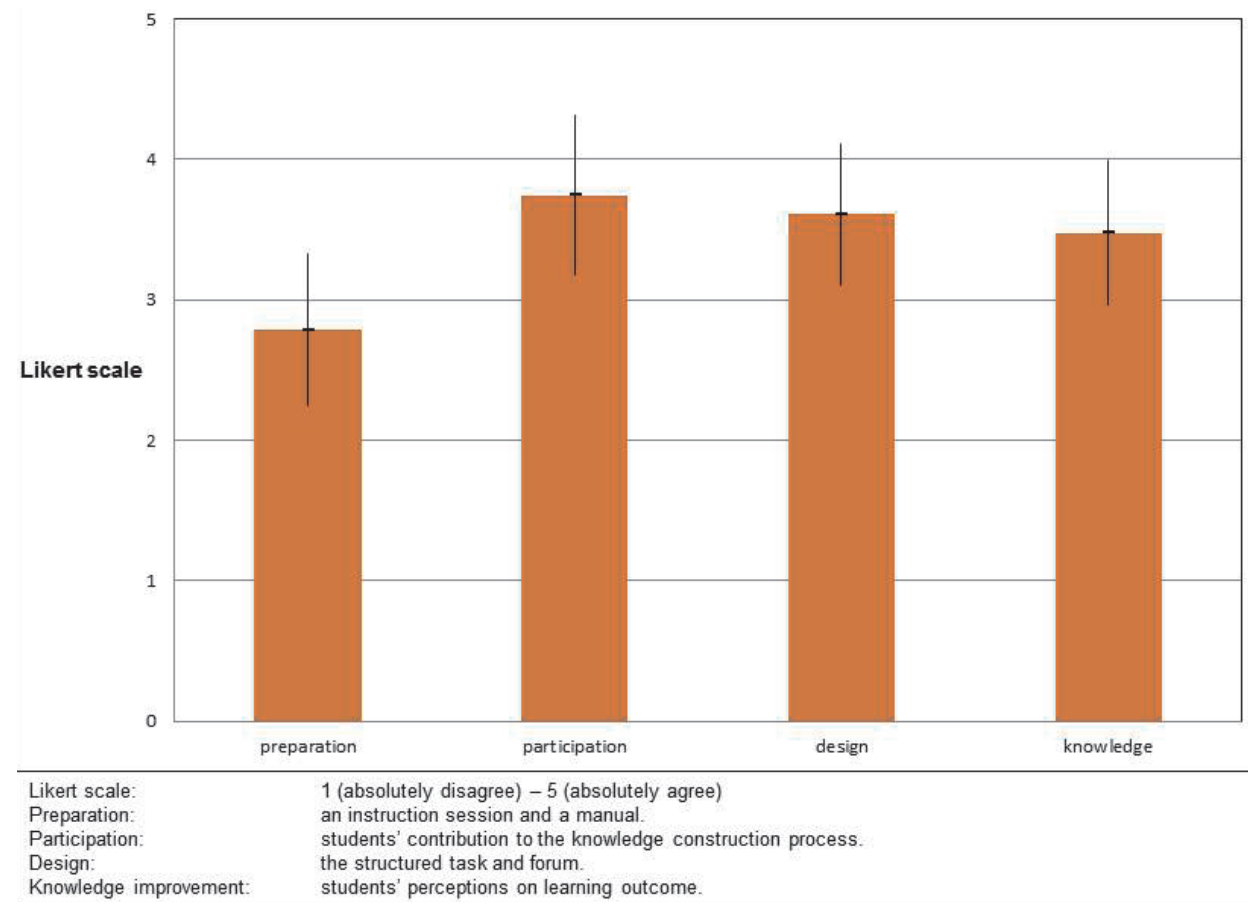

Figure 2 Mean ( \pm SD questionnaire scores of students' perceptions of various aspects of asynchronous CSCL

\section{Interview results}

All students of the experimental group $(\mathrm{N}=21)$ participated in the interviews, which concentrated upon the items 'Preparation', 'Participation', 'Design', and 'Knowledge improvement'.

Regarding 'Preparation', students felt that exact instructions were missing on how to start the discussion and at what moment the discussion was sufficient. The instruction manual did not provide sufficient structure or guidelines that were clear enough for students to start and finish their discussions. Further structuring the task by scripting on how to start and finish the task could be a solution here. For 'Participation' it appeared that students who participated actively, contributed positively on peers' CAT papers by critical reading and providing critical feedback. Furthermore, these active students felt motivated to reflect more critically on their own CAT paper before and after discussion.

Some remarks these students made were: "First, I thought this collaborative task was senseless, however afterwards I think this collaborative task adds value to the individual task". "I critically read the paper of my peers and provided them with feedback. My peers read my paper critically and send useful feedback to me. I think it was a good collaboration". Students who did not participate actively thought their papers were of a good quality already and considered participation in an electronic discussion on CAT papers as time-consuming and extra work load to their elective. 
Students mentioned low participation in the discussion group, by not providing and receiving any feedback on the posted CAT papers. These students provided statements such as: "Lack of time is the reason that my activity of sending postings to other students during discussion was less. The elective is busy already, I had to study at the evening, and had to conduct several other tasks. This resulted in few possibilities to discuss the CAT paper on the internet." Another student replied: "I consider a CAT paper of a $6^{\text {th }}$ year medical student that good, that further improvement is not necessary, and in that way I believe this task was useless to our kind of students". A group of students are willing to provide peers with feedback on their papers, and critically consider and revise their own paper as well. Another group of students consider their paper of high quality already, and/or experience high time pressure during their elective, and therefore these students do not contribute by sending feedback on their peers' papers. The willingness to participate in discussion seems to depend on the perceived quality of students' CAT papers, and perceived time pressure as well.

Regarding 'Design', students thought that the lay-out of the CSCL environment was clear, and that the tools were user-friendly. The structured forum was considered appropriate to the specific CAT task, and convenient to have a quick overview of all students' contributions. The opportunity to have access to the CSCL environment anytime and anywhere during the elective was appreciated by these students. Students answered: "the learning environment was that clear, probably is no manual needed", and "the learning environment was well-arranged and I think there are no changes needed". However, students mentioned difficulties with the learning environment such as hard to log-in, to up- and download articles and CAT papers, and to find the 'drop-box' for storing articles and papers as well. Apparently, when students have to overcome technical difficulties in a CSCL environment this negatively influences their motivation to participate to the discussion.

Finally, 'Knowledge improvement' was reported in scientific reasoning, specifically in topic 1: 'the process of literature search regarding the clinical problem', and in topic 3: 'the quality, respectively the amount of evidence in the cited research used to address the clinical problem'.

A student stated: "I've learned to formulate the research question better, and improved the process of my literature search".

\section{Students' knowledge construction}

Overall, 171 postings were recorded during the asynchronous forum discussions. After content-analysis, 391 units of analysis could be identified, which were differentiated to the discussions of either revised or unrevised papers. For the distribution of analysis units was skewed, the units are presented by frequency and median (95\% Confidence Interval) values (Table 2). Overall, a significantly higher activity during discussion (sending postings) was found in the group of revised than unrevised papers $(P<0.03)$. 


\section{CHAPTER 3}

This difference could be exclusively linked to a higher task-focused activity in the group of revised papers $(P<0.01)$. In more detail, significantly more analysis units were found on levels of knowledge construction in the group of revised papers, i.e. Category 5. 'Opinions' $(\mathrm{P}<0.005)$, Category 6.: 'Argumentation' $(\mathrm{P}<0.02)$, and Category 7.: 'Broaden \& deepen' $(\mathrm{P}<0.003)$.

Table 2 Students' activity during discussions according to the Rainbow system, classified by revised and unrevised papers

\begin{tabular}{|c|c|c|c|c|c|}
\hline & \multicolumn{2}{|c|}{$\begin{array}{l}\text { revised paper discussions } \\
(\mathrm{n}=6)\end{array}$} & \multicolumn{2}{|c|}{$\begin{array}{l}\text { unrevised paper discussions } \\
(\mathrm{n}=15)\end{array}$} & \multirow[t]{3}{*}{$\begin{array}{l}\text { Mann-Whitney } \\
\text { U test }\end{array}$} \\
\hline & total units & units per discussion & total units & units per discussion & \\
\hline & freq. & median (min.-max.) & freq. & median (min.-max) & \\
\hline $\begin{array}{l}\text { Outside activity } \\
\text { (Category 1.) }\end{array}$ & 3 & $0.5(0-1)$ & 15 & $0.0(0-2)$ & $P>.5$ \\
\hline Cat. 2. Social Relation & 38 & $5.0(1-18)$ & 66 & $4.0(2-6)$ & $P>.6$ \\
\hline $\begin{array}{l}\text { Cat. 3. Interaction } \\
\text { management }\end{array}$ & 15 & $1.0(0-7)$ & 37 & $1.0(1-3)$ & $P>.6$ \\
\hline $\begin{array}{l}\text { Non-task-focused activity } \\
\text { (Category 2. \& 3.) }\end{array}$ & 53 & $6.0(1-25)$ & 103 & $5.0(3-9)$ & $P>1.0$ \\
\hline Cat. 4.Task Management & 13 & $1.0(0-10)$ & 8 & $0.0(0-0)$ & $P>.09$ \\
\hline Cat. 5.Opinions & 75 & $12.5(2-22)$ & 33 & $2.0(1-3)$ & $P>.005$ \\
\hline Cat. 6. Argumentation & 51 & $7.0(1-21)$ & 22 & $1.0(0-2)$ & $P>.02$ \\
\hline Cat. 7. Broaden and Deepen & 14 & $1.5(0-8)$ & 1 & $0.0(0-0)$ & $P>.003$ \\
\hline $\begin{array}{l}\text { Task-focused activity } \\
\text { (Category 4.-7.) }\end{array}$ & 153 & $22.0(4-50)$ & 64 & $3.0(2-7)$ & $P>.01$ \\
\hline $\begin{array}{l}\text { Discussion activity } \\
\text { (Category 1.-7.) }\end{array}$ & 209 & $28.0(10-74)$ & 182 & $11.0(6-16)$ & $P>.03$ \\
\hline
\end{tabular}

\section{Overall CAT paper marks}

Overall and topic paper marks (mean; \pm SD) of the control and the experimental group are presented in Table 3. The Kappa of the inter-rater reliability of the overall mean paper marks for the two independent experts was 0.719 ( $p<0.001), 95 \% \mathrm{Cl}(0.517$ 0.921 ). Since this value can be considered to be sufficiently high, the marks as presented in Table 4 represent the average of the two independent expert ratings. Comparison of pre CAT paper marks $(n=21)$ and post CAT paper marks $(n=21)$, as well as comparison of the post CAT papers of the experimental group $(n=21)$ and the control group CAT papers $(n=23)$ revealed no significant differences on the mean overall mark and topic marks. 
Table 3 Mean $( \pm S D)$ values of CAT paper marks in the control and experimental group

\begin{tabular}{|c|c|c|c|}
\hline & \multirow{2}{*}{$\begin{array}{l}\text { Control group } \\
\text { CAT papers } \\
(n=23)\end{array}$} & \multicolumn{2}{|c|}{ Experimental group } \\
\hline & & $\begin{array}{l}\text { Pre CAT papers } \\
(n=21)\end{array}$ & $\begin{array}{l}\text { Post CAT papers } \\
(n=21)\end{array}$ \\
\hline & mean $( \pm S D)$ & mean $( \pm S D)$ & mean $( \pm S D)$ \\
\hline Mean overall mark & $6.6( \pm 1.1)^{*}$ & $6.7( \pm 0.9)^{*}$ & $6.8( \pm 0.8)^{*}$ \\
\hline \multicolumn{4}{|l|}{ Topic 1: } \\
\hline Literature search regarding the clinical problem & $6.6( \pm 1.1)^{*}$ & $6.8( \pm 1.1)^{*}$ & $6.8( \pm 1.2)^{*}$ \\
\hline \multicolumn{4}{|l|}{ Topic 2: } \\
\hline Design \& execution of cited research & $6.9( \pm 1.0)^{*}$ & $6.8( \pm 1.0)^{*}$ & $7.0( \pm 0.8)^{*}$ \\
\hline \multicolumn{4}{|l|}{ Topic 3: } \\
\hline Quality of evidence in cited research & $6.4( \pm 1.2)^{*}$ & $6.5( \pm 1.0)^{*}$ & $6.5( \pm 0.9)^{*}$ \\
\hline
\end{tabular}

* calculated on marks of six subtopics

Legend:

- $\quad$ Control group CAT papers: original CAT papers, sent in for expert feedback without any intervention.

- $\quad$ Experimental group Pre CAT papers: original students' CAT papers before intervention.

- $\quad$ Experimental group Post CAT papers: students' revised and unrevised CAT papers after intervention, sent in for expert feedback.

\section{Pre and post CAT paper marks}

Six students decided to revise their paper after peer discussion. These six revised post CAT papers were paired with the corresponding six pre CAT papers. Each individual pair of these pre CAT and post CAT papers was evaluated on overall mark (mean; \pm SD), as presented in Table 4. The revised post CAT papers 1, 3, 4 and 5 were marked quite equally, while a mark increase was found for paper $6(+2.6)$, and a decrease for paper 2 $(-0.7)$. Mark comparison of each individual pair of CAT papers showed no significant differences.

Table 4 Mean $( \pm S D)$ of individual paired CAT paper marks in the experimental group

\begin{tabular}{llll}
\hline & $\begin{array}{l}\text { Pre CAT paper mark } \\
\text { mean }( \pm S D)\end{array}$ & $\begin{array}{l}\text { Post CAT paper mark } \\
\text { mean }( \pm S D)\end{array}$ & $\begin{array}{l}\text { Paired-Samples T test } \\
\text { P-value }\end{array}$ \\
\hline Overall CAT papers & $6.7( \pm 0.6)$ & $6.9( \pm 0.8)$ & $\mathrm{p}<0.1^{\text {\$ }}$ \\
CAT paper 1 & $7.6( \pm 0.6)$ & $7.5( \pm 0.6)$ & $\mathrm{p}<0.3^{*}$ \\
CAT paper 2 & $7.2( \pm 0.9)$ & $6.5( \pm 0.6)$ & $\mathrm{p}<0.09^{*}$ \\
CAT paper 3 & $7.1( \pm 0.5)$ & $7.2( \pm 1.1)$ & $\mathrm{p}<0.8^{*}$ \\
CAT paper 4 & $6.8( \pm 0.6)$ & $6.9( \pm 0.6)$ & $\mathrm{p}<0.4^{*}$ \\
CAT paper 5 & $6.7( \pm 1.3)$ & $6.6( \pm 1.4)$ & $\mathrm{p}<0.3^{*}$ \\
CAT paper 6 & $5.0( \pm 1.4)$ & $7.6( \pm 1.4)$ & $\mathrm{p}<0.09^{*}$ \\
\hline
\end{tabular}

\$calculated on marks of six papers

* calculated on marks of six subtopic 
An overview of the twenty-one pre and six (revised) post CAT paper marks are visualized in figure 3. The left panel shows the individual scores of 21 pre CAT papers. The right panel shows the scores of 6 post CAT papers that were revised after students' discussion. The lines connect the paper marks of the pre and (revised) post CAT papers. Although arguable, papers that were marked below six were considered as low quality papers. Overall, five (24\%) pre CAT papers were considered as low quality papers. After discussion, only one of these CAT papers (CAT paper 6) was improved that much, that this paper reaches the range of the high quality post CAT papers.

\section{Expert grade on pre and post CAT paper}

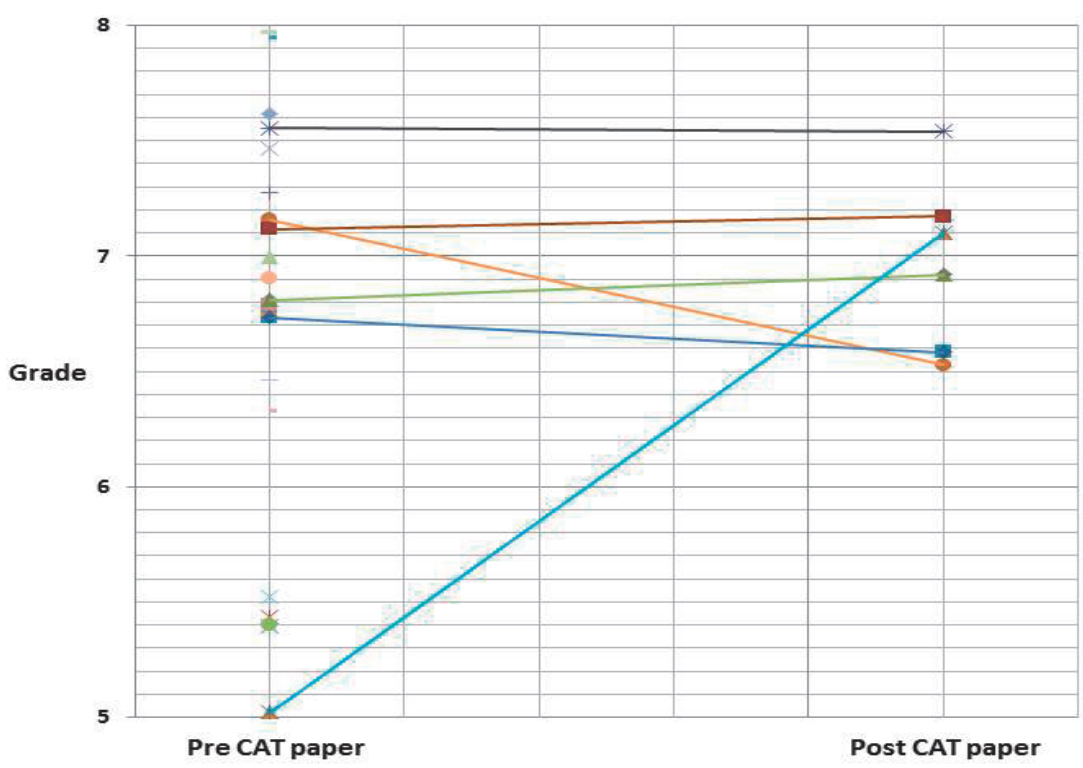

Figure 3 Overview of pre and post paper grades

\section{DISCUSSION}

In the present study on the value of an asynchronous discussion forum in a CSCL environment on a clinical problem from the workplace environment, it is demonstrated that students report positive perceptions on 'Participation', 'Design', and 'Knowledge improvement' of the asynchronous discussion forum in a CSCL environment. Discussions with active knowledge construction lead to the revision of CAT papers. However, revision seems not to depend on the quality of these papers.

It has been demonstrated earlier that the success of a discussion forum in a CSCL environment depends on, among other factors, the intensity of the online activity of students (Kreijns et al. 2005; Dillenbourg et al. 2009; Wang et al. 2000). 
The results of present study confirm the former research outcome that high discussion participation is associated with high task-focused activity and higher levels of knowledge construction (De Wever et al. 2006b; Koops et al. 2011; Schellens et al. 2005). The consequence of this observation is that students should be maximally stimulated in discussion to reach a high level of knowledge construction. The results of the questionnaire and the interview items: 'task preparation', 'participation', 'design of the CSCL environment', and 'knowledge improvement' could shed more light on how students can be engaged to actively discuss their papers.

The task preparation in present study is perceived as a weak factor by students. Although this authentic task with a structured discussion forum was designed as selfdirected, by following the characteristics of a discussion task (Dillenbourg et al. 2009), students mention that exact instructions to start and to end the discussion are missing.

Secondly, the participation in the forum discussion is perceived positive by students. They feel stimulated to provide critical feedback on their peers' contributions, as well as to critically reflect on their own paper. In contrast, other students mention a low participation grade in the discussion group, and doubt that they can profit from a thorough discussion of their own or others paper. Therefore, low participation in a discussion forum is a serious cause for concern in an online collaborative task. As such it should be clear for students that the productivity of the individual and group achievement highly depends on the willingness to participate in relevant discussions (Janssen et al. 2007).

Thirdly, also the design of the CSCL environment is positively perceived by students during clinical workplace learning. This perception concerns the accessibility of the forum and the high flexibility in time and place of the asynchronous learning tool. In workplace learning, for instance in a medical elective, this is an essential feature, for learning in such an environment is unpredictable and time demanding (Chumley-Jones et al. 2002; Cook et al. 2008; Cook 2009). Providing that the design is adequately adapted to their needs, the experience of an appropriate design can stimulate students to participate. However, in contrast a number of students who decide not to revise their paper mention negative, merely practical aspects of the design of the learning environment, such as log-in difficulties, problematic up- and downloads of an article or paper, and difficulties in navigation. Problems in the design of a CSCL environment have therefore to be avoided, for this has been associated with low quality of interaction and learning outcome (Du 2008).

Finally, students report a knowledge improvement on scientific reasoning; specificalIy on topic 1 'literature search' and on topic 3 'quality and amount of evidence'. To our surprise, this positive perception is not visible by grading. When we take into account that the subjective perception of their knowledge improvement can be caused by an improved insight into one or two subtopics only, it is well possible that such a subtopic revision hardly affects the overall mean grading of the particular paper. 
Indeed, the overall grading is based upon the average rating of six subtopics in each of the 3 prescribed discussion topics. Therefore the statistical chance to significantly improve the mean overall marks of the post papers was rather slight.

One of the limitations of this study is the relatively small experimental group of twenty-one students. To prevent confounding of unmotivated students in case of an obligatory participation, students were asked to voluntarily participate in this study, which reduced the amount of non-participating students. Another limitation is a low activity during discussion as seen with students with unrevised papers. Although it can be expected that a voluntarily participation would maximally motivate students to participate, there still remain active and less active students in discussion. This could be of influence on knowledge construction, on knowledge improvement and on learning outcome. Another limitation was that it was not quite clear to students when to start and when to end the discussion. This could be of influence on students' activity during discussion as well. Anyhow, all participating students initiated activity during discussion on their CAT papers with their peers in a self-directed way. More guidance in preparation on the discussion task on how to start and when to end their discussion could be provided by a script (Dillenbourg et al. 2009).

The outcome of present research strongly suggests that in future research more attention should be given to stimulate students' collaborative activity on the discussion forum in order to improve knowledge construction. And moreover, to further elaborate on the ideas of Cook and colleagues (2008; 2009) in future research, more attention should be paid to the question of "how and when" e-learning should be applied in medical education, to support students with different affective factors such as motivation, attitude and emotional state on knowledge construction and collaboration in an asynchronous discussion forum in a CSCL environment (Jones et al. 2005; Joiner et al. 2003). This resonates well with research on collaborative learning in general (Johnson et al. 2007), where clear guidelines have been identified for scaffolding collaborative learning. We need to find similar conditions or scaffolds for collaborative learning in a CSCL environment, and future research should be directed at identifying these. Furthermore, students' knowledge construction during discussion should be analyzed in more detail to consider students' learning improvement, instead of using paper marks as outcome measure. 


\section{CONCLUSION}

Medical students show positive subjective perceptions on their participation in the discussion forum, on the design of the CSCL environment, and on their knowledge improvement after discussion on an asynchronous forum. Medical students revising their written task after discussion show significantly higher active knowledge construction during an asynchronous discussion forum in a CSCL environment. Active knowledge construction of medical students during an asynchronous discussion forum in a CSCL environment is not necessarily paralleled by a significantly higher expert grading. 


\section{REFERENCES}

- $\quad$ Aronoff, S., Evans, B., Fleece, D., Lyons, P., Kaplan, L., Rojas, R.. Integrating Evidence Based Medicine into undergraduate medical education: combining online instruction with clinical clerkships. Teaching and Learning in Medicine.. 2010, 22(3),219-223. DOI: 10.1080/10401334.2010.488460.

- Baarda, D., De Goede, M., Teunissen, J.. Basisboek Kwalitatief onderzoek (Basics of qualitative research). 2001. Noordhoff Uitgevers, the Netherlands. ISBN: 9001807704.

- Baker, M., Andriessen, J., Lund, K., Amelsvoort, van, M., Quignard, M. Rainbow: A framework for analyzing computer-mediated pedagogical debates. Computer-Supported Collaborative Learning. 2007; 2,315-357. DOI: 10.1007/s11412-007-9022-4.

- Chumley-Jones, H., Dobbie, A., Alford, C.L. Web-based learning: Sound educational method or hype? A review of the evaluation literature. Academic Medicine. 2002, 77(10),86-s93.

- Cook, D., Levinson, A., Garside, S. Internet-based learning in the health professions: a Meta-analysis. Journal of American Medical Association. 2008; 300(10),1181-1196. DOI:10.1001/jama.300.10.1181.

- Cook, D. The failure of e-learning research to inform educational practice, and what we can do about it. Medical Teacher. 2009;31:158-162. DOI 10.1007/s10459-007-9089-8

- De Wever, B. The impact of structuring tools on knowledge construction in asynchronous discussion groups, doctoral dissertation. 2006(a). University of Gent, Belgium.

- De Wever, B., Van Winckel, M., Valcke, M. Discussing patient management online: The impact of roles on knowledge construction for students interning at the pediatric ward. Advances in Health Sciences Education. 2006(b);13 (1),25-42. DOI: 10.1007/s10459-006-9022-6

- Dewiyanti, S. Learning together: a positive experience. The effect of reflection on group processes in an asynchronous computer-supported collaborative learning environment. Ph.D.-Dissertation. 2005. Datawyse Maastricht. ISBN: 90-3582251-X

- Dillenbourg, P., Järvelä, S., Fischer, F. The evolution of research on computer-supported collaborative learning. From design to orchestration. In: Ludvigsen, S., de Jong, T., Lazonder, A., Barnes, S. (eds) Technology-enhanced learning: principles and products. 2009. Springer Science \& Business Media B.V. DOI: 10.1007/978-1-4020-9827-7_1

- $\quad$ Driscoll, M. Psychology of learning for instruction. 2005. Pearson Allyn and Bacon. ISBN: 0205375196.

- Du J., Zhang, K., Olinzock, A., Adams, J. Graduate Students' perspectives on meaningful nature of online discussions. Journal of Interactive Learning Research. 2008; 19(1),21-36.

- Janssen, J., Erkens, G., Kanselaar, G., Jaspers, J. Visualization of participation: Does it contribute to successful computer-supported collaborative learning? Computers \& Education. 2007; 49,1037-1065.

- Johnson, D., Johnson, R., Smith, K. The state of cooperative learning in postsecondary and professional settings. Educational Psychology Review. 2007, 19,15-29. DOI 10.1007/s10648-006-9038-8.

- Joiner, R., Issroff, K. Tracing success: graphical methods for analyzing successful collaborative problem solving. Computers \& Education. 2003; 41,369-378. DOI:10.1016/j.compedu.2003.08.001.

- Jones, S., McCann, J. Virtual learning environments for time-stressed and peripatetic managers. The Journal of Workplace Learning. 2005, 17(5/6),359-369. DOI 10.1108/13665620510606779

- Komoroski, E. Use of e-mail to teach residents pediatric emergency medicine. Archives of Pediatrics \& Adolescent Medicine. 1998; 152,1141-1146.

- Koops W., Van der Vleuten C., De Leng B., Oei S., Snoeckx L. Computer-supported collaborative learning in the medical workplace: Students' experiences on formative peer feedback of a critical appraisal of a topic paper. Medical Teacher. 2011;33:6:e318-323. DOI: 10.3109/0142159X.2011.575901

- Koops W., Van der Vleuten C., De Leng B., Snoeckx L. Computer supported collaborative learning in a clerkship: an exploratory study on the relation of discussion activity and revision of critical appraisal papers. BMC Medical Education. 2012; 12,79. DOI:10.1186/1472-6920-12-79.

- Kreijns, K., Kirschner, P., Jochems, W., Van Buuren, H. Measuring perceived sociability of computersupported collaborative learning environments. Computers \& Education. 2005; 49,176-192. DOI: 10.1016/j.compedu.2005.05.004 
- $\quad$ Laurillard, D. Rethinking university teaching: a conversational framework for the effective use of learning technologies Second Edition. 2002. Routledge Falmer, Falmer Press. ISBN: 0415256798.

- Leong, S., Baldwin,C., Adelman, A. Integrating web-based computer cases into a required clerkship: development and evaluation. Academic Medicine. 2003; 78(3),295-301.

- Mahdizadeh, H. Student collaboration and learning. Knowledge construction and participation in an asynchronous computer-supported collaborative learning environment in higher education, doctoral dissertation, 2007. Wageningen university, the Netherlands.

- Morrison, G., Ross, S., Kemp, J. Designing effective instruction. 2004. John Wiley \& Sons, Inc. ISBN: 0470074264.

- Parkes J., Hyde C., Deeks J. Milne, R. Teaching critical appraisal skills in health care settings. Cochrane Database of Systematic Reviews 2001, Issue 3. Art. No.: CD001270. DOI: 10.1002/14651858.CD001270.

- Rourke, L., Anderson, T., Garrison, D., Archer, W. Methodological Issues in the Content Analysis of Computer Conference Transcripts International Journal of Artificial Intelligence in Education. 2001; 12,1. DOI:10.1152/advan.00026.2004.

- Sauvé, S., Lee, H., Meade, M., Lung, J., Farkouh, M., Cook, D., Sackett, D. The Critically Appraised Topic: A Practical Approach to Learning Critical Appraisal. Annuals of the Royal College Physicians and Surgeons of Canada. 1995; 28,396-398.

- Scardamalia, M., Bereiter, C. Computer support for knowledge-building communities. The Journal of the Learning Sciences. 1994; 3(3), 265-283.

- Schellens, T. Valcke, M. Collaborative learning in asynchronous discussion groups: What about the impact on cognitive processing? Computers in Human Behavior. 2005; 21, 957-975. DOI: 10.1016/j.chb. 2004.02.025.

- Servais E., LaMorte, W., Agarwal, S., Moschetti, W., Malliputti, S., Moulton, S. Teaching surgical decisionmaking: An interactive, web-based approach. Journal of surgical research. 2006; 134,102-106. DOI:10.1016/j.jss.2005.11.583

- Shokar, G., Burdine, R., Callaway, M., Bulik, R. Relating student performance on a family medicine clerkship with completion of web cases. Family medicine. 2005, 37(9),620-622.

- Stahl, G. Meaning and interpretation in collaboration. In B. Wasson, S. Ludvigsen \& U. Hoppe (ed) Designing for change in networked learning environments: Proceedings of the international conference on computer support for collaborative learning. CSCL '03, Bergen, Norway, Kluwer Publishers. 2003; 523-532.

- Van der Meijden, H. Knowledge construction through CSCL: Student elaborations in synchronous, asynchronous and 3-D learning environments. 2005. Drukkerij Tamminga, Duiven, The Netherlands. ISBN10:9090197184.

- Veerman, A. Computer-supported collaborative learning through argumentation. Doctoral dissertation, 2000. University of Utrecht, the Netherlands.

- Veldhuis-Diermanse, A. CSCLearning? Participation, learning activities and knowledge construction in computer-supported collaborative learning in higher education, Doctoral dissertation, 2002. Wageningen University, the Netherlands.

- Versloot, B. , Erkens, G. Onderwijs en onderwijskunde: betrokkenen en perspectieven (Education and educational sciences: participants and perspectives). In: Versloot, B., Erkens, G., Stokking K, Wessum, van, L. (ed) Van onderwijs naar leren (From education towards learning), Garant, Leuven-Apeldoorn, Belgiumthe Netherlands. 2000, 1-18. ISBN: 9044110950.

- Wang, A., Newlin, M. Characteristics of students who enroll and succeed in psychology web-based classes. Journal of educational psychology. 2000; 92(1), 137-143. DOI: 10.1037//0022-0663.92.1.137.

- Westendorp, M.W., McGraw, R.C. Computer-assisted instruction of carpal bone radiograph interpretation. Medical Teacher. 2002, 24(6),605-608.

- Williams, C., Aubin, S., Harkin, P., Cottrell, D. A randomized, controlled, single-blind trial of teaching provided by a computer-based multimedia package versus lecture. Medical Education. 2001; 35(35),847854. 



\section{ABSTRACT}

Background: Medical students in clerkship are continuously confronted with real and relevant patient problems. To support clinical problem solving skills, students perform a Critical Appraisal of a Topic (CAT) task, often resulting in a paper. Because such a paper may contain errors, students could profit from discussion with peers, leading to paper revision. Active peer discussion by a Computer Supported Collaborative Learning (CSCL) environment show positive medical students perceptions on subjective knowledge improvement. High students' activity during a discussion in a CSCL environment demonstrated higher task-focused discussion reflecting higher levels of knowledge construction. However, it remains unclear whether high discussion activity influences students' decisions revise their CAT paper.

Objective: The aim of this research is to examine whether students who revise their critical appraisal papers after a discussion in a CSCL environment show more taskfocused activity and discuss more intensively on critical appraisal topics than students who do not revise their papers.

Methods: Forty-seven medical students, stratified in subgroups, participated in a structured asynchronous online discussion of individual written CAT papers on self-selected clinical problems. The discussion was structured by three critical appraisal topics. After the discussion, the students could revise their paper. For analysis purposes, all students' postings were blinded and analyzed by the investigator, unaware of students characteristics and whether or not the paper was revised. Postings were counted and analyzed by an independent rater, Postings were assigned into outside activity, non-task-focused activity or task-focused activity. Additionally, postings were assigned to one of the three critical appraisal topics. Analysis results were compared by revised and unrevised papers.

Results: Twenty-four papers (51.6\%) were revised after the online discussion. The discussions of the revised papers showed significantly higher numbers of postings, more task-focused activities, and more postings about the two critical appraisal topics: "appraisal of the selected article(s)", and "relevant conclusion regarding the clinical problem".

Conclusion: An asynchronous discussion forum in a CSCL environment can support medical students in the execution and critical appraisal of authentic tasks in the clinical workplace. Revision of CAT papers appears to be related to discussions activity, more specifically reflecting high task-focused activity of critical appraisal topics. 


\section{BACKGROUND}

In the clinical phase of the medical curriculum, during a clerkship, students learn primarily in the authentic context of the workplace (O'Brien et al. 2010; Chittenden et al. 2009) and are continuously confronted with clinical problems. Students have a preference for learning from clinical problems in the workplace because these problems are real and relevant to them (Collis et al. 2004; Manley et al. 2009). To train clinical problem solving skills, medical students often use critical appraisal (Manley et al. 2009; Rhodes et al. 2007; Feltovich et al. 1989), defined as: "The process of assessing and interpreting evidence (usually by published research) by systematically considering its validity (closeness to the truth), results and relevance to the individual's work" (Hyde et al. 2000; Parkes et al. 2009). A practical task here is a Critical Appraisal of a Topic (CAT). This CAT task requires a student to first formulate a clinical question relating to a clinical problem encountered in the workplace. Next, the literature is investigated for articles offering evidence with relevance to the problem. Then, the student has to appraise the evidence critically, in relation to the etiology, diagnosis, prognosis, therapy and followup of the case in question, and to describe the evidence table. Finally, the student considers the value of the evidence and presents the conclusion related to the clinical problem concerned (Parkes et al. 2009; Sauvé et al. 1995). A CAT paper written by an individual student can be considered as a first draft which has not been subject to any review. Since a CAT paper may contain errors like those of fact, calculation and interpretation, students can profit from a thorough discussion of their CAT paper with peers. Irrespective of whether they decide to revise or not revise the CAT paper afterwards (Sauvé et al. 1995; Bennet et al. 1987). However, such a collaborative activity poses logistical problems, particularly when students are dispersed over different training locations. Part of a solution may be provided by a Computer Supported Collaborative Learning $(\mathrm{CSCL})$ environment, enabling students to engage in a structured, asynchronous discussion, independent of place and time (Van Bruggen et al. 2002; Medélez et al. 2001; Michaelsen et al. 2002; Kreijns et al. 2002; Kreijns et al. 2003; Davis et al. 2008). However, it has been shown that such collaborative activities do not automatically result in positive learning outcomes. The success of an asynchronous discussion forum in a CSCL environment depends on, among other factors, the intensity of the online activity within groups and its results (Kreijns et al. 2005; Dillenbourg et al. 2009; Wang et al. 2000). Research on the use of an asynchronous discussion forum in a CSCL environment by university students has shown that a more intense activity during discussions is associated with high task-focused discussion activity, reflecting specifically higher levels of knowledge construction (Schellens et al. 2005). In a recent study, we demonstrated that medical students perceived subjective (knowledge) improvement of their learning outcomes during asynchronous discussions of an authentic CAT task in a CSCL environment (Koops et al. 2011). 
Although high activity during asynchronous discussions in a CSCL environment appears to be associated with high task-focused activity, it remains unclear whether students' discussion activity influences their decision to whether or not to revise the CAT paper. Furthermore, it is not clear whether high discussion activity on CAT topics influences students to revise their CAT paper.

In present study we hypothesized that students who revise their CAT paper after discussing its content with peers on a forum in a CSCL environment, conduct an extensive discussion, with more task-focused activity, than students who do not revise their paper. Besides it is hypothesized that students who revise their CAT paper show more discussion activity on critical appraisal topics than students who do not revise their CAT paper.

Thus, the first objective of present study was to examine whether students who revised their paper showed more task-focused activity compared with students with unrevised papers. The second objective was to evaluate whether students who revised their paper showed more discussion activity on critical appraisal topics, compared with student with unrevised CAT papers.

This paper details the process of a peer discussion of a CAT paper on a clinical problem, and reports the effects on students activity during a discussion forum in a CSCL environment.

\section{METHODS}

\section{Participants and task}

Between January 2008 and June 2010, all sixth year students of the medical curriculum of the Faculty of Health, Medicine and Life Sciences, Maastricht University, the Netherlands participated in an eighteen-week clerkship in a discipline of their choice. The clerkships were offered in nine different hospitals, eight in the Netherlands and one in Austria. One of the tasks during the clerkship required students to investigate a selfselected clinical problem encountered during the elective and to write a pre-formatted critical appraisal of a topic (CAT) paper on it, a task with which students were familiar from ample earlier experience.

\section{Study design}

Sixty-six medical students were invited by e-mail for this study, forty-seven of which voluntarily agreed to participate in the study. The participants received informed consent before the start of the study and were free to withdraw their cooperation at any time. They were randomly allocated into sixteen groups, fifteen groups of three and one group of two students. 
Each student uploaded his individual CAT paper to a 'drop-box', read the papers of the peers in his group and provided his comments in an asynchronous structured discussion forum in the open source CSCL environment DOKEOS (www.dokeos.com). The discussion was moderated by the student who's paper was subject of discussion. After the online discussion, students were given the opportunity to revise their paper (Figure 1). Students had only access to their own discussion forum. The discussion activity and postings were automatically filed by the CSCL environment.

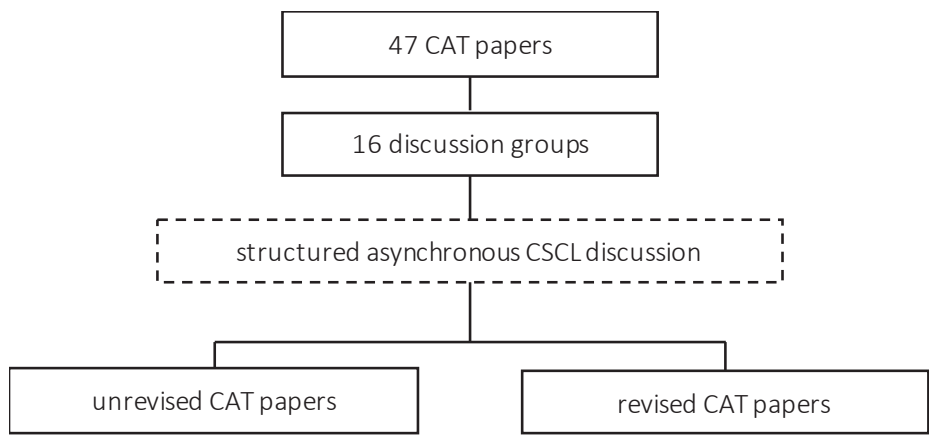

Figure 1 study design

In order to structure the discussion of the CAT papers, the students were asked to address three topics: (1) the selection of the clinical problem, the formulation of the clinical question and the process of the literature search, (2) the study design and the methods of the article(s) selected on the basis of the literature search and, (3) the evidence provided by the article(s) that could be used to address the clinical problem and relevant clinical conclusions regarding the clinical problem. To help students with the CSCL discussion task, they received, by e-mail, an instruction manual containing information about the design and use of the CSCL environment, and about the schedule for the discussion. Students were free to make arrangements in their discussion group regarding the sequence of CAT papers to be discussed, as long as each individual CAT paper was discussed within a two-week period. Students received a password and logon code to access the CSCL environment and could familiarize themselves with the environment before starting the actual task.

\section{instruments and statistical analysis}

\section{Content analysis of students' postings on collaborative problem solving activity}

To identify the type of collaborative problem solving activity, content analysis of students' postings was performed according to the validated Rainbow system (Baker et al. 2007). This content analysis system has been developed for any educational discussion forum, but to our knowledge, has not been used in medical education before. 


\section{Chapter 4}

According to the Rainbow system, there are seven categories of communicative interaction, which can be grouped into three collaborative problem solving activities, i.e., outside activity, non-task-focused activity or task-focused activity (Table 1). Regarding the group of task-focused activity, the categories 5, 6 and 7 are considered to reflect the highest levels of knowledge construction, respectively. In the present study, all postings of students CAT paper discussions were blinded. Thus, the analysis of the postings was conducted by the investigator, unaware of student characteristics and whether or not the paper, which was subject to the discussion, was revised. In principle individual postings were considered as a unit of analysis. However, when a posting contained multiple activities it was split into different units of analysis, which were then coded separately (Schellens et al. 2005; Rourke et al. 2001). All units of analysis were counted and descriptive statistics were calculated for the three collaborative problem solving activities, as well as for the seven categories.

Table 1 Rainbow system for content analysis; activity, category, and category definitions

\begin{tabular}{|c|c|c|}
\hline \multicolumn{3}{|c|}{ Content analysis system for collaborative problem solving activity (Baker et al., 2007 ) } \\
\hline $\begin{array}{l}\text { Collaborative } \\
\text { problem solving } \\
\text { activity }\end{array}$ & $\begin{array}{l}\text { Category of } \\
\text { communicative } \\
\text { interaction }\end{array}$ & Definition \\
\hline Outside & 1. Outside & $\begin{array}{l}\text { Any interaction that is not concerned with interacting in order } \\
\text { to carry out the defined task, e.g., talk about last night's party. }\end{array}$ \\
\hline \multirow[t]{2}{*}{ Non-task-focused } & 2. Social relation & $\begin{array}{l}\text { Interaction concerned with managing the students' social } \\
\text { relations with respect to the task, e.g., greeting, leave-taking, } \\
\text { politeness. }\end{array}$ \\
\hline & $\begin{array}{l}\text { 3. Interaction } \\
\text { management }\end{array}$ & $\begin{array}{l}\text { Interaction concerned with managing the interaction itself, } \\
\text { e.g., coordination (who will speak and who will not), } \\
\text { establishing contact, topic shifting. }\end{array}$ \\
\hline \multirow[t]{4}{*}{ Task-focused } & 4. Task management & $\begin{array}{l}\text { Management of the progression of the task itself, e.g., } \\
\text { planning what is to be discussed, establishing whether } \\
\text { problem is solved or not. }\end{array}$ \\
\hline & 5. Opinions & $\begin{array}{l}\text { Interaction concerned with expressing opinions about the } \\
\text { topic of discussion, e.g., beliefs, acceptances. }\end{array}$ \\
\hline & 6. Argumentation & $\begin{array}{l}\text { Expression of (counter-) arguments directly related to a thesis, } \\
\text { or theses themselves, e.g., requests for justification }\end{array}$ \\
\hline & 7. Broaden and deepen & $\begin{array}{l}\text { Interaction concerned with (counter-)arguments linked to } \\
\text { (counter-) arguments, argumentative relations and the } \\
\text { meaning of arguments themselves, e.g., elaborations of } \\
\text { arguments, definition. }\end{array}$ \\
\hline
\end{tabular}

2. Content analysis of students' postings on CAT topics of discussion. 
To examine the discussion on the three critical appraisal topics as well as the corresponding CAT task elements (Table 2), all analysis units identified as either category $5 .$, 6., or 7. of task-focused activity (see higher) were labelled to one of the topics and their elements. Descriptive statistics were performed on the frequency of analysis unit per discussion topic, overall, as well as on revised and unrevised papers.

Table 2 Prescribed critical appraisal topics and elements of the CAT task

\begin{tabular}{ll}
\hline Critical appraisal topics of discussion & CAT task elements \\
\hline (1) Literature search regarding clinical problem & Preparation for executing the literature search \\
& Strategy of the literature search \\
& Results of the literature search \\
& Study design \\
(2) Appraisal of the selected article(s) & Study method \\
& Study outcome \\
(3) Relevant conclusion regarding the clinical & Evidence table of appraised article(s) \\
problem & Relevant clinical conclusion regarding clinical problem \\
\hline
\end{tabular}

A Mann-Whitney $U$ test for independent samples was performed to compare the analysis units of the revised and the unrevised papers, with regard to the three collaborative problem solving activities and their corresponding categories, and with regard to the three critical appraisal topics and their elements. $P<.05$ was considered statistically significant. CAT task elements were identified in either the revised or unrevised papers, and compared by a Chi-square test.

\section{RESULTS}

Content analysis of students' postings on collaborative problem solving activity.

A total of 1582 units of analysis was identified in students' postings in the various discussion groups (Table 3 ). In the discussions of revised papers $(n=24)$, the number of analysis units was almost twice as high as in the unrevised paper discussions $(n=23)$ $(P<.001)$. Non-task-focused activity was identified in discussions on revised papers (23.2\%), as well as on unrevised papers (25.8\%).

Task-focused activity was relatively high in both revised (73.9\%), and unrevised paper discussions (69.5\%), but, in absolute terms, the task-focused activity in the revised paper discussions was double as high as in the unrevised paper discussions $(P<.000)$. 


\section{CHAPTER 4}

A statistically significant higher number of units in the category 5. (Opinions; $P<.000$ ), 6. (Argumentation; $P<.005$ ), and 7. (Broaden and Deepen; $P<.016)$ was found in the revised paper discussions compared with the unrevised paper discussions. Effect sizes (Cohens 'd) on these categories were large, with exception of category 7.

Table 3 Frequencies and descriptive statistics of discussion activity in the revised and unrevised paper discussions

\begin{tabular}{|c|c|c|c|c|c|c|}
\hline & \multicolumn{2}{|c|}{$\begin{array}{l}\text { analysis units of } \\
\text { revised papers } \\
(n=24)\end{array}$} & \multicolumn{2}{|c|}{$\begin{array}{l}\text { analysis units of } \\
\text { unrevised papers } \\
(n=23)\end{array}$} & \multirow[t]{2}{*}{$\begin{array}{l}\text { Mann- } \\
\text { Whitney } \\
\text { U test }\end{array}$} & \multirow[t]{2}{*}{$\begin{array}{l}\text { Effect size } \\
\text { (Cohens d') }\end{array}$} \\
\hline & freq. & $\begin{array}{l}\text { median } \\
\text { (min.-max.) }\end{array}$ & freq. & $\begin{array}{l}\text { median } \\
\text { (min.-max.) }\end{array}$ & & \\
\hline $\begin{array}{l}\text { Outside activity } \\
\text { (Category 1.) }\end{array}$ & 29 & $1(0-10)$ & 26 & $1(0-4)$ & $\mathrm{P}<.716$ & 0.05 \\
\hline Cat. 2. Social Relation & 189 & $5.5(0-26)$ & 96 & $3(0-11)$ & $P<.071$ & 0.68 \\
\hline Cat. 3. Interaction Management & 50 & $2(0-19)$ & 47 & $1(0-7)$ & $P<.610$ & 0.04 \\
\hline $\begin{array}{l}\text { Non-task-focused activity } \\
\text { (Category 2. \& 3.) }\end{array}$ & 239 & $7.5(0-31)$ & 143 & $6(0-15)$ & $\mathrm{P}<.179$ & 0.57 \\
\hline Cat. 4. Task Management & 64 & $2(0-19)$ & 28 & $1(0-7)$ & $P<.107$ & 0.48 \\
\hline Cat. 5. Opinions & 481 & $17.5(10-40)$ & 269 & $10(0-30)$ & $P<.000$ & 1.04 \\
\hline Cat. 6. Argumentation & 186 & $7.5(0-19)$ & 80 & $4(0-9)$ & $P<.005$ & 0.98 \\
\hline Cat. 7. Broaden and Deepen & 29 & $0(0-5)$ & 8 & $0(0-5)$ & $P<.016$ & 0.54 \\
\hline $\begin{array}{l}\text { Task-focused activity } \\
\text { (Category 4.-7.) }\end{array}$ & 760 & $29(11-65)$ & 385 & $15(0-45)$ & $P<.000$ & 1.17 \\
\hline $\begin{array}{l}\text { Discussion activity } \\
\text { (Category 1.-7.) }\end{array}$ & 1028 & $36(15-94)$ & 554 & $20(1-53)$ & $P<.001$ & 1.08 \\
\hline
\end{tabular}

Content analysis of students' postings on CAT topics of discussion.

Analysis units of task-focused activity relating to the three critical appraisal topics of discussion are presented in Table 4. For the topic 2 'appraisal of the selected article(s)' and topic 3 'relevant conclusion regarding the clinical problem', the number of units was significantly higher in the revised than in the unrevised paper discussions. Effect sizes (Cohens 'd) on these topics were large, as well. 
Table 4 Frequency of analysis units of revised and unrevised paper in critical appraisal topics of discussions

\begin{tabular}{|c|c|c|c|c|c|c|}
\hline \multirow[b]{2}{*}{$\begin{array}{l}\text { Critical appraisal topics of } \\
\text { discussion }\end{array}$} & \multicolumn{2}{|c|}{$\begin{array}{l}\text { analysis units of } \\
\text { revised papers } \\
(n=24)\end{array}$} & \multicolumn{2}{|c|}{$\begin{array}{l}\text { analysis units of } \\
\text { unrevised papers } \\
(n=23)\end{array}$} & \multirow{2}{*}{$\begin{array}{l}\text { Mann-Whitney } \\
\text { U test } \\
\text { P-value }\end{array}$} & \multirow[t]{2}{*}{$\begin{array}{l}\text { Effect size } \\
\text { (Cohens'd) }\end{array}$} \\
\hline & freq. & $\begin{array}{l}\text { median } \\
(\min -\max )\end{array}$ & freq. & $\begin{array}{l}\text { median } \\
\text { (min-max) }\end{array}$ & & \\
\hline $\begin{array}{l}\text { (1) Literature search regarding } \\
\text { the clinical problem }\end{array}$ & 258 & $9.74(2.75-30.16)$ & 173 & $8(0-22.43)$ & $P<.070$ & 0.56 \\
\hline $\begin{array}{l}\text { (2) Appraisal of the selected } \\
\text { article(s) }\end{array}$ & 276 & $9.72(1.41-32.64)$ & 137 & $4.7(0-15)$ & $P<.007$ & 0.86 \\
\hline $\begin{array}{l}\text { (3) Relevant conclusion regarding } \\
\text { the clinical problem }\end{array}$ & 162 & $6.5(0-12.69)$ & 47 & $1.6(0-9.29)$ & $P<.000$ & 1.54 \\
\hline
\end{tabular}

The frequency and percentages of CAT task elements identified in either revised or unrevised paper discussion are presented in Table 5. Overall, CAT task elements were discussed more in the revised than in the unrevised papers. In the revised paper discussions, every prescribed CAT topic and corresponding CAT task element was identified, where in the unrevised CAT paper discussions, the elements of topic (2): 'Study design' and 'Study outcome' were not identified as elements under discussion. Significantly more critical appraisal topics of discussion identified in the revised paper were found in topic (1): 'Preparation for executing literature search', and 'Strategy of literature search', every CAT task element of topic (2), and in topic (3): 'Relevant clinical conclusion regarding clinical problem'.

Table 5 CAT task elements of critical appraisal topics discussed in revised and unrevised papers

\begin{tabular}{|c|c|c|c|c|}
\hline $\begin{array}{l}\text { Critical appraisal topics } \\
\text { of discussion }\end{array}$ & CAT task elements identified in discussion & $\begin{array}{l}\text { Revised } \\
\text { papers } \\
\mathrm{N}=24\end{array}$ & $\begin{array}{l}\text { Unrevised } \\
\text { papers } \\
\mathrm{N}=23\end{array}$ & $\begin{array}{l}\text { Chi-square } \\
\text { P-value }\end{array}$ \\
\hline \multirow{3}{*}{$\begin{array}{l}\text { (1) Literature search } \\
\text { regarding the clinical } \\
\text { problem }\end{array}$} & Preparation for executing literature search & 15 & 5 & $P<.005$ \\
\hline & Strategy of the literature search & 24 & 12 & $P<.000$ \\
\hline & Results of the literature search & 11 & 7 & $P<.278$ \\
\hline \multirow{3}{*}{$\begin{array}{l}\text { (2) Appraisal of } \\
\text { the selected article(s) }\end{array}$} & Study design & 15 & 0 & $\mathrm{P}<.000$ \\
\hline & Study population & 24 & 11 & $P<.000$ \\
\hline & Study outcome & 4 & 0 & $P<.041$ \\
\hline \multirow{2}{*}{$\begin{array}{l}\text { (3) Relevant conclusion } \\
\text { regarding the clinical } \\
\text { problem }\end{array}$} & Evidence table of appraised research & 6 & 2 & $P<.137$ \\
\hline & $\begin{array}{l}\text { Relevant clinical conclusion regarding } \\
\text { clinical problem }\end{array}$ & 18 & 6 & $\mathrm{P}<.001$ \\
\hline
\end{tabular}




\section{DISCUSSION}

The results of the present study indicate that an asynchronous discussion forum in a Computer Supported Collaborative Learning environment can effectively support medical students to learn collaboratively during clinical clerkships. By the execution of an authentic task such as a critical appraisal of a relevant clinical problem, students are stimulated to critically discuss and revise their critical appraisal paper. Students' paper revision seems to be associated with an increased activity during discussions with peers, and to be related to higher task-focused discussion activity as well as a more intense discussion of critical appraisal topics.

The discussion of students who revise their CAT paper substantially differs from that of students who do not revise. Revised paper discussions are more extensive, social and task-focused, reflecting both low and higher levels of knowledge construction. These findings are consistent with results obtained by a CSCL environment in university classrooms and medical workplace showing that both social interaction and task-orientation are typical for an active discussion leading to higher levels of knowledge construction (Schellens et al. 2006; De Wever et al. 2006). Furthermore, students who revise their CAT paper after discussing its content with peers in a discussion forum in a CSCL environment show more discussion activity on critical appraisal topics, with a strong focus on the CAT task elements: strategy of the literature search, and appraisal of the study population. Other elements identified under discussion in the majority of revised papers were: 'preparation for executing literature search'; 'study design', and 'relevant clinical conclusion regarding clinical problem'.

A study among undergraduate medical students showed no differences in critical appraisal skills between students who received a computer-based learning session and students who attended classroom lectures (Davis et al. 2008). However, two studies on medical students' individual learning in on-line critical appraisal modules during clinical clerkships showed positive outcomes in favor of on-line learning.

One study measured medical students' pre- and post-test scores on an individual pre-determined critical appraisal task, and showed improvement in executing a search strategy and in appraise a study design (Aronoff et al. 2010), while another study compared the critical appraisal skills of medical students after on-line learning with those of students without intervention, and reported a higher quality of the literature search after on-line learning (Schilling et al 2006). In the above-mentioned studies as well as in present study, students worked individually on a critical appraisal task. However, in present study students worked on a self-selected clinical problem extended with a collaborative discussion on their paper with peers. These differences in study design could have influenced the finding in present study that not only identical CAT task elements were identified, but moreover, even more critical appraisal elements were found. 
A limitation of present study is the challenge to control all variables in an on-line collaborative discussion. By the design of a structured discussion task a certain control of variables is achieved. Despite of this structured discussion, it cannot be excluded that students' performance in course may have influenced them to revise their paper. However, this phenomenon likely has played a minor role since it concerned last year medical students with a comparable knowledge level. Moreover, all students participating in the present study performed several critical appraisals during the previous four years of the medical curriculum, and thus can be considered to be experienced in writing a CAT paper. Therefore, it was expected that participants may not have felt great urgency to discuss the task. It thus is remarkable that, even after intensive training the skill in performing a CAT, $51 \%$ of the students revised their paper after collaborative online discussion. Therefore, students can profit by a peer discussion of their papers, irrespective whether they revise or not revise their paper (Sauvé et al. 1995; Bennet et al. 1987). Besides the effect of discussion with peers, other factors could have influenced students to revise the CAT paper. First, since students participated voluntarily in this study they were probably highly motivated to discuss with peers. Secondly, it can be emphasized that motivation for discussion is high because this critical appraisal task was related to a self-selected, authentic clinical problem. Even though it cannot be excluded that the discussion itself could stimulate students to discuss. Another limitation is that the content analysis was performed by one researcher. Since the analysis was conducted according to a structured and validated analysis system (Baker et al. 2007), it seemed safe to assume that the analysis was well executed.

Furthermore, it cannot be denied that the sample of participants was relatively small. However, high effect sizes reveal a high effect on the students' activity in discussion on two levels of knowledge construction and on two critical appraisal topics of the discussion.

In CSCL research, much attention has been given to measuring outcomes in terms of cognition, skills, critical thinking and problem solving, but research on what influences student learning during discussions is scant. Further research on a larger scale could be useful to clarify the learning processes during discussions and to what extent these processes affect the interaction among students and knowledge construction in discussion forum in a CSCL environment. A controlled study comparing students interaction between an intense and limited discussion could be an interesting intervention for further research. Furthermore, it could be interesting to further research the question whether implementing an on-line discussion could be applied as a framework to support students' learning in existing courses. 


\section{CONCLUSIONS}

An asynchronous discussion forum in a Computer Supported Collaborative Learning environment can support medical students in critically appraising clinical problems encountered during learning in the workplace. An increase in activity during the discussions seems to be related to more task-focused activities and more discussion of critical appraisal topics. 


\section{REFERENCES}

- $\quad$ Aronoff, S., Evans, B., Fleece, D., Lyons, P., Kaplan, L., Rojas, R.. Integrating Evidence Based Medicine into undergraduate medical education: combining online instruction with clinical clerkships. Teaching and Learning in Medicine.. 2010, 22(3),219-223. DOI: 10.1080/10401334.2010.488460.

- Baker, M., Andriessen, J., Lund, K., Amelsvoort, van, M., Quignard, M. Rainbow: A framework for analyzing computer-mediated pedagogical debates. Computer-Supported Collaborative Learning. 2007; 2,315-357. DOI: 10.1007/s11412-007-9022-4.

- Bennet, K., Sackett, D., Haynes, R., Neufeld, V., Tugwell, P., Robert, R. A controlled trial of teaching critical appraisal of the clinical literature to medical students. The Journal of the American Medical Association. 1987, 257(18),2451-2454.

- Chittenden, E., Henry, D., Saxena, V., Loeser, H., O’Sullivan, P. Transitional clerkship: An experiential course based on workplace learning theory. Academic Medicine 2009; 84(7):872-876.

- Collis, B., Margaryan, A. Applying activity theory to computer-supported collaborative learning and workbased activities in corporate settings. Educational Technology Research \& Development. 2004; 52(4), 1042-1629.

- Davis J, Crabb S, Rogers E, Zamora J, Khan K: Computer-based teaching is as good as face to face lecturebased teaching of evidence based medicine: a randomized controlled trial. Medical Teacher. 2008; 20,302-307. DOI: 10.1080/01421590701784349

- De Wever, B., Van Winckel, M., Valcke, M. Discussing patient management online: The impact of roles on knowledge construction for students interning at the pediatric ward. Advances in Health Sciences Education. 2006; 13(1), 25-42. DOI: 10.1007/s10459-006-9022-6

- Dillenbourg, P., Järvelä, S., Fischer, F. The evolution of research on computer-supported collaborative learning. From design to orchestration. In: Ludvigsen, S., de Jong, T., Lazonder, A., Barnes, S. (ed) Technology-enhanced learning: principles and products. 2009. Springer Science \& Business Media B.V. DOI: 10.1007/978-1-4020-9827-7_1

- Feltovich PJ, Spiro RJ, Coulson RL: The nature of conceptual understanding in biomedicine: the deep structure of complex ideas and the development of misconceptions. In: The Cognitive Sciences in Medicine. 1989. Edited by Evans DA, Patel VL. Cambridge. MIT press.

- Hyde, C., Parkes J., Deeks J., Milne, R. Systematic review of effectiveness of teaching critical appraisal. ICRF/NHS Centre for Statistics in Medicine. 2000. Institute of Health Sciences Oxford.

- Koops W., Van der Vleuten C., De Leng B., Oei S., Snoeckx L. Computer-supported collaborative learning in the medical workplace: Students' experiences on formative peer feedback of a critical appraisal of a topic paper. Medical Teacher. 2011;33:6:e318-323. DOI: 10.3109/0142159X.2011.575901

- Kreijns, K., Kirschner, P., Jochems, W. The Sociability of Computer-Supported Collaborative Learning Environments. Educational Technology \& Society. 2002; 5(1),8-22.

- Kreijns K, Kirschner P, Jochems W: Identifying the pitfalls for social interaction in computer-supported collaborative learning environments: a review of the research. Computers in Human Behaviour. 2003; 19,335-353.

- Kreijns, K., Kirschner, P., Jochems, W., Van Buuren, H. Measuring perceived sociability of computersupported collaborative learning environments. Computers \& Education. 2005; 49,176-192. DOI: 10.1016/j.compedu.2005.05.004

- Manley K, Titchen, A, Hardy S: Work-based learning in the context of contemporary health care education and practice: A concept analysis. Practice development in health care. 2009; 8(2),87-127. DOI: 10.1002/pdh.284.

- Medélez E, Burgun A, Le Duff F, Le Beux P: Design of a CSCL Environment for Clinical Reasoning Learning and Problem-Based Learning in Medicine. In: Patel, V., Rogers, R., Haux, R. (ed.) Studies in Health Technology and Informatics. 2001. MedInfo, IOS Press.

- Michaelsen L, Bauman Knight A, Dee Fink L: Team-based learning: a transformative use of small groups. 2002. Westport, USA: Praeger Publishers. 


\section{CHAPTER 4}

- O'Brien B., Poncelet, A. Transition to clerkship courses: Preparing students to enter the workplace. Academic Medicine 2010; 85(12), 1-8. DOI: 10.1097/ACM.0b013e3181fa2353

- Parkes J., Hyde C., Deeks J., Milne, R. Teaching critical appraisal skills in health care settings. Cochrane Database of Systematic Reviews. 2009; issue 3, art. No.: CD001270. DOI: 10.1002/14651858.CD001270.

- Rhodes, G., Shiel, G. Meeting the needs of the workplace and the learner through work-based learning. Journal of workplace learning 2007, 19(2), 173-187. DOI 10.1108/13665620710735648

- Rourke, L., Anderson, T., Garrison, D., Archer, W. Methodological Issues in the Content Analysis of Computer Conference Transcripts International Journal of Artificial Intelligence in Education. 2001; 12,1. DOI:10.1152/advan.00026.2004.

- Sauvé, S., Lee, H., Meade, M., Lung, J., Farkouh, M., Cook, D., Sackett, D. The Critically Appraised Topic: A Practical Approach to Learning Critical Appraisal. Annuals of the Royal College Physicians and Surgeons of Canada. 1995; 28,396-398.

- Schellens, T. Valcke, M. Collaborative learning in asynchronous discussion groups: What about the impact on cognitive processing? Computers in Human Behavior. 2005; 21, 957-975. DOI: 10.1016/ j.chb.2004.02.025.

- Schellens, T. Valcke, M. Fostering knowledge construction in university students through asynchronous discussion groups. Computers \& Education. 2006; 46, 349-370. DOI: 10.1016/j.compedu.2004.07.010

- Schilling, K., Wiecha, J., Polineni, D., Khalil, S. An interactive web-based curriculum on evidence-based medicine: design and effectiveness. Family Medicine. 2006; 38(2),126-132.

- Van Bruggen, J., Kirschner, P., Jochems, W. External representation of argumentation in CSCL and the management of cognitive load. Learning and Instruction. 2002; 12, 121-138.

- Wang, A., Newlin, M. Characteristics of students who enroll and succeed in psychology web-based classes. Journal of educational psychology. 2000; 92(1), 137-143. DOI: 10.1037//0022-0663.92.1.137. 


\section{ABSTRACT}

Background: In higher education, it is common practice that expert teachers provide feedback on students' learning tasks. From a social-constructivist educational perspective, it could be valuable to replace or complement expert feedback by feedback by multiple peers. When students are physically dispersed, an asynchronous discussion forum in a computer-supported collaborative learning $(\mathrm{CSCL})$ environment can be a valuable tool to facilitate the exchange of feedback by multiple peers. The question that arises, then, is whether feedback by multiple peers within an asynchronous discussion forum in a CSCL environment could lead to task revision of such good quality that it obviates, either entirely or in part, the need for expert feedback.

Objective: The present study has sought to explore three various phases of task review: 1) feedback on the task by multiple peers on an asynchronous discussion forum in a $\mathrm{CSCL}$ environment, 2) task revision ensuing from feedback by multiple peers, and 3 ) expert feedback on the task afterwards.

Methods: We invited 52 medical students, whom we consequently divided into subgroups, to participate in a review process consisting of three phases. In the first phase, students provided their group members with peer feedback on their written protocols in an asynchronous discussion forum in a CSCL environment-embedded structured asynchronous online discussion forum. In the second phase, students were given the opportunity to revise their task accordingly. In the final phase, an expert (teacher) provided feedback on the final submitted task if deemed necessary. The outcome of the review process was considered profitable if expert feedback was not forthcoming, whereas the opposite was true when expert feedback did ensue. The volume and type of peer and expert feedback were analysed. Descriptive statistics were calculated and differences between revised and unrevised protocols were statistically tested.

Results: 46 (89\%) of the students we invited participated in the review process. Of the 46 written protocols, 18 (39\%) received feedback from multiple peers, one third of which were revised accordingly. 32 protocols (70\%) were of such good quality that expert feedback remained absent. Of the 14 protocols that did receive expert feedback, $71 \%$ had remained unrevised. In their provision of feedback, peers and experts largely attached similar weights to the various protocol topics. Experts did not differ in the type of feedback they provided on revised and unrevised protocols, whereas peers provided significantly more trivial comments (Criticism and Off-task comments) on protocols that stayed unrevised after discussion. 
Conclusions: In a process in which a complex task is reviewed students make significant contributions. Feedback by multiple peers is an effective instrument to help students revise a written task. The majority of protocols, by definition, do not require expert feedback, regardless of whether or not they have been previously revised. Experts mostly provide feedback on tasks that stayed unrevised after peer discussion within a computer supported collaborative learning environment. Cutting back on trivial comments in peer feedback could enhance students' discussions and the task revision ensuing from them. 


\section{INTRODUCTION}

In higher education, it is common practice that expert teachers provide feedback on students' learning tasks. Regardless of the objective quality of the feedback provided, students are more likely to accept feedback from experts than from peers (Beason 1993; Strijbos et al. 2010). Students regard expert teachers as a more credible source purely based on their status (Watling et al. 2012). Still, peer feedback could be an interesting alternative or a valuable addition to expert feedback; when feedback is provided between peers, both provider and receiver might understand it better (Vedder 1985; Cho et al. 2010). Indeed, peers live and work in comparable circumstances, share the same language and knowledge and are more familiar with the difficulties their fellow students may struggle with. Research suggests that peer feedback on the work of fellow students facilitates critical thinking and reflection (Cho et al. 2006). This can be accomplished by letting students help each other improve the quality of their task without expert intervention. Research on classroom education has demonstrated that paper revision ensuing from peer feedback can improve the task's quality without the provision of expert feedback (Rucker et al. 2003; Atwater et al. 2000).

The benefits of peer feedback can be even greater when feedback on a task is provided by multiple peers (Cho et al. 2010). Such feedback is more reliable and founded than single peer feedback because more problems, omissions and blind spots are detected. Besides this, feedback from various sources promotes error reduction because the collective consensus tends to be accepted as valid or true (Cho et al. 2010). Feedback by multiple peers also fits in very well with a social-constructivist educational perspective, which considers learning as an interactive, dynamic, and self-directed process, during which students collaboratively construct ideas and concepts. This process leads to the acquisition of new knowledge that builds on existing knowledge (Mahdizadeh 2007; Biemans 1997; Veldhuis-Diermanse 2002).

With the advent of online learning environments it has become easier to organize feedback by multiple peers. Such environments make it possible for students to effectively exchange tasks and accompanying feedback, even if they are physically dispersed. An asynchronous discussion forum in a computer-supported collaborative learning (CSCL) environment offers such an opportunity to conveniently exchange peer feedback (Van Bruggen et al. 2002; Medélez et al. 2001; Kreijns et al. 2002; Kreijns et al. 2003; Davis et al. 2008). In an asynchronous discussion forum in a CSCL environment students convey their ideas, thoughts and additional explanations by writing them down (Stahl 2003; Mahdizadeh 2007). The advantage of such a communication method is that peer feedback can be easily recorded and analyzed for research purposes. Research has shown that students appreciate the opportunity to discuss their task of a clinical topic on an asynchronous discussion forum in a CSCL environment (De Wever et al. 2006; Koops et al 2011). 
Whether an asynchronous discussion forum in a CSCL environment is successful, however, also depends on the intensity of student activity within the discussion groups. Higher levels of task-focused discussion activity by students were positively related to higher levels of knowledge construction (Kreijns et al. 2005; Dillenbourgh et al. 2009; Wang et al. 2000) and to actual task revision (Schellens et al. 2005; Koops et al. 2012; Koops et al. 2014).

The question that arises, then, is whether feedback by multiple peers in an asynchronous discussion in a CSCL environment could lead to task revision of such good quality that it obviates, either entirely or in part, the need for expert feedback.

The present study therefore seeks to explore three various phases of task review: 1) feedback on the task by multiple peers in an asynchronous discussion forum in a CSCL environment, 2) task revision ensuing from feedback by multiple peers, and 3) expert feedback on the task afterwards.

\section{Research questions}

The following research questions will be addressed accordingly:

- Does the content of peer and expert feedback vary in accordance with their pertinence to revised and unrevised tasks?

- What is the volume of feedback provided by multiple peers on students' tasks during an asynchronous discussion forum in a CSCL environment?

- What is the effect of feedback by multiple peers on task revision ensuing from discussion?

- What is the effect of task revision on the volume of expert feedback?

\section{MATERIALS AND METHODS}

\section{Participants}

Fifty-two medical students of the Faculty of Health, Medicine and Life Sciences at the Maastricht University, the Netherlands, participated in this study that was conducted in the period spanning August 2010 to December 2010 and July 2012 to September 2012. 


\section{ChAPTER 5}

Task

In preparation for a clinical research elective in the final year of their 6-year training programme, each individual master student had to autonomously write a fully-detailed research protocol. In the earlier years of this programme, students had practiced their skills in either writing parts of a research protocol individually or prepared a whole research protocol in cooperation with peers. For the present task students were free to formulate their ideas as long as they adhered to the protocol structure, which should typically include four topics, each of which addressing a number of specific subtopics (see table 1).

Table 1 Research protocol structure, covering four predefined topics and related subtopics.

\begin{tabular}{ll}
\hline Required topics & Specific subtopics to address \\
\hline 1. Introduction \& background & Problem definition \\
& Literature references \\
& Previous study results \\
& Relevance of the present study \\
2. Hypothesis \&research question(s) & Hypothesis \\
3. Research population & Research question(s) \\
& Inclusion criteria \\
& Patient selection \\
& Power; sample size \\
& Exclusion criteria \\
4. Research design & Methods \\
& Design \\
Data-analysis \\
Statistics \\
Selection procedure \\
Intervention(s)
\end{tabular}

After this process of creative writing, all students were invited to participate in a review process consisting of three consecutive phases. The first phase engaged students in an asynchronous discussion forum in a CSCL environment in which they addressed the strong and weak points of the topics and subtopics of each other's written protocols. It was not mandatory to comment on each subtopic when there were no grounds for discussion. The second phase conceded all students time to revise their protocol following the discussion. Protocol revision was not obligatory. In the third phase, students had to submit their final written protocol to an expert (teacher) for feedback. From a group of 10 experts, one was randomly selected and invited to provide feedback on the topics and subtopics of a particular protocol when deemed necessary. Experts did not know if a protocol had been revised or not. All students gave informed consent before the start of the study. 


\section{Study design}

Students were randomly assigned to 17 discussion groups, 16 of which consisted of 3 students each and 1 counting 4 students. To effectively partake in the review process, all students received an e-mail that contained the names of the other students in their group, an instruction manual, the description of the peer review task and a time schedule with set deadlines. The instruction manual provided information on the design and use of the asynchronous discussion forum in the CSCL environment. Group members were free to decide on the time schedule of the discussions conjointly, but had to inform the principal investigator of the time the discussion would start and end, the order in which the individual research protocols would be discussed, and the sequence of topics to be discussed. All students were imposed two deadlines. The first one specified the date by which their individual protocols were to be uploaded, that is, one week before the start of the discussion so as to allow for an adequate preparation. The second concerned the date by which their final research protocols had to be submitted for expert feedback. All students were given the opportunity to familiarize themselves with the learning environment (Blackboard ${ }^{(}$) and its asynchronous discussion forum in a CSCL environment before starting the discussion. Discussion threads were only visible to the members of the discussion group and to the principal investigator.

After submission of the final protocol each student was asked to indicate which subtopics of the protocol had been revised in response to peer feedback. Each final protocol was evaluated by an expert who provided feedback as he or she thought fit. Expert feedback was sent to the student and to the principal investigator of this study.

\section{MEASUREMENT INSTRUMENTS AND STATISTICAL ANALYSIS}

\section{Content of peer and expert feedback}

First, peer and expert feedback was explored by categorizing them according to the nature of feedback: (1) Content; i.e. feedback regarding the discussion of the text; (2) Editorial; i.e. feedback regarding the justification of the text, or (3) Explication; i.e. feedback regarding the request for explanation of the text.

Second, the content of peer and expert feedback was further analyzed in more detail because this feedback expresses the highest value to the learning process. To this end, the content of peer and expert feedback was categorized in seven types, according to Cho and colleagues (2006). Table 2 describes these seven types and their definitions in more detail. 


\section{CHAPTER 5}

Table 2 Feedback categorized by type with their definition (Cho et al. 2006)

\begin{tabular}{|c|c|}
\hline Types of feedback & Definition \\
\hline Directive comments & Suggests a specific change particular to the writer's paper. \\
\hline Nondirective comments & $\begin{array}{l}\text { Suggests a nonspecific change that would apply to any paper. } \\
\text { Comment on a detail without suggesting a change. }\end{array}$ \\
\hline Criticism comments & $\begin{array}{l}\text { Gives a critical or negative evaluation of the paper or a portion of the paper; } \\
\text { points out an underdeveloped area. No suggestions for improvement are } \\
\text { offered. }\end{array}$ \\
\hline Praise comments & $\begin{array}{l}\text { Describes the paper or a portion of the paper positively, including encouraging } \\
\text { remarks. }\end{array}$ \\
\hline Summary comments & Recapitulation of the main points of the paper or a portion of the paper. \\
\hline Off task comments & $\begin{array}{l}\text { Comments do not fit any of the code categories; } \\
\text { the comments are ambiguous, or a rating was given without written comment. }\end{array}$ \\
\hline
\end{tabular}

For the classification of the nature and type of both peer and expert feedback a descriptive statistical analysis was performed. For data was ordinal, we used a Mann-Whitney $U$ test for two independent samples to compare the nature and type between peer feedback and expert feedback.

\section{The review process}

As described earlier, the review process consisted of three consecutive phases of which we only used peer feedback on the content of the research protocol. In phase 1, students provided their fellow group members with feedback on some or all of their protocols' subtopics. Next, in phase 2, if the peer feedback required so, students could choose whether or not to revise their individual protocol. Finally, in phase 3 the expert provided feedback according to the protocol structure when deemed appropriate. The different scenarios possible for each phase led to a theoretical classification of eight different review processes a students' protocol could potentially proceed through (see Table 3 ). 
Table 3 Classification of possible review processes

\begin{tabular}{lllll}
\hline $\begin{array}{l}\text { Review } \\
\text { process }\end{array}$ & $\begin{array}{l}\text { Phase 1: } \\
\text { Feedback by multiple peers? Protocol revision? }\end{array}$ & $\begin{array}{l}\text { Phase 3: } \\
\text { Expert feedback? }\end{array}$ & $\begin{array}{l}\text { Expected benefits } \\
\text { accruing to } \\
\text { student's protocol }\end{array}$ \\
\hline 1 & Yes & Yes & Yes & - \\
2 & Yes & Yes & No & + \\
3 & Yes & No & Yes & - \\
4 & Yes & No & No & + \\
5 & No & No & Yes & - \\
6 & No & No & No & + \\
7 & No & Yes & Yes & not to occur \\
8 & No & Yes & No & not to occur \\
\hline
\end{tabular}

Due to the absence of expert feedback, the highest profit was expected to accrue to students in review processes 2,4 , and 6 . Students profited maximally from feedback by multiple peers in review process 2 , because no further expert feedback ensued after revision. As regards review process 4, although peer feedback was present, protocols were not revised and neither did they receive subsequent feedback from experts. Hence, the student's decision not to revise was correct; therefore, this process was also considered to be profitable to students. Finally, review process 6 reflects the congruence of opinion between peers and experts, as neither peers nor experts provided feedback, nor did any revision ensue.

The inferences that can be drawn from review processes 1, 3, or 5 are less positive. In each of these processes, experts still had comments, regardless of whether or not any prior discussion of subtopics had taken place among peers and whether or not protocols had been revised accordingly. Under these circumstances the review process was not considered to be profitable. As to the final two review processes ( 7 and 8 ), these were not considered further, since it never happened that a protocol would be revised without prior peer feedback. It follows that six different review processes remain that merit consideration. We therefore classified all final protocols into these six review processes. We consequently counted the number of protocols in each of these review processes and calculated descriptive statistics.

Phase 1: Feedback by multiple peers

Only students' postings describing content feedback were considered to contain relevant peer feedback (Baker et al. 2007; Rourke et al. 2001; Schellens et al. 2005). We counted all these postings and performed a descriptive statistical analysis at subtopic level classified by revised or unrevised protocols. Consequently, we grouped all subtopic-related data and presented these per topic.

For the data was nominal, we used a Chi-square test for two independent samples to compare the number of protocols with or without peer feedback. 


\section{CHAPTER 5}

Phase 2: Protocol revision

The decision to revise (one or more subtopics of) a protocol in response to peer feedback was analyzed by counting and classifying postings as per their pertinence to revised or unrevised protocols. We performed a descriptive statistical analysis at the subtopic level of both classifications. We subsequently grouped all subtopic-related data and presented these per topic. For the data was nominal, we used a Chi-square test for two independent samples to compare the number of postings on topics between the groups of revised and unrevised protocols after peer feedback.

Phase 3: Expert feedback

We counted postings of expert feedback on the content of research protocols and performed a descriptive statistical analysis at subtopic level as classified by revised or unrevised protocols. Consequently, we grouped all subtopic-related data and presented these per topic. For the data was nominal, we used a Chi-square test for two independent samples to compare the amount of recorded expert feedback between the revised and unrevised protocols.

\section{RESULTS}

Of the 52 students we invited, 46 (89\%) actively participated in the online discussions and provided peer feedback. Fourteen discussion groups had only active participants; two discussion groups had one inactive student; and one group of three students showed no activity at all. It was unclear why these students did not participate.

\section{Content of peer and expert feedback}

Figure 1 depicts the results on the nature of the postings of peer and expert feedback, i.e. content, editorial, and explication. In total, peers exchanged 333 discussion postings where experts provided 196 feedback postings on the final protocol. On every category of the nature, students send more postings than experts. On the content, peers provided $41 \%$ more postings than experts $(p<.035)$. On editorial and explication, peers sent more postings than experts as well, $24 \%$ and $47 \%$ respectively. 


\section{Nature of postings}

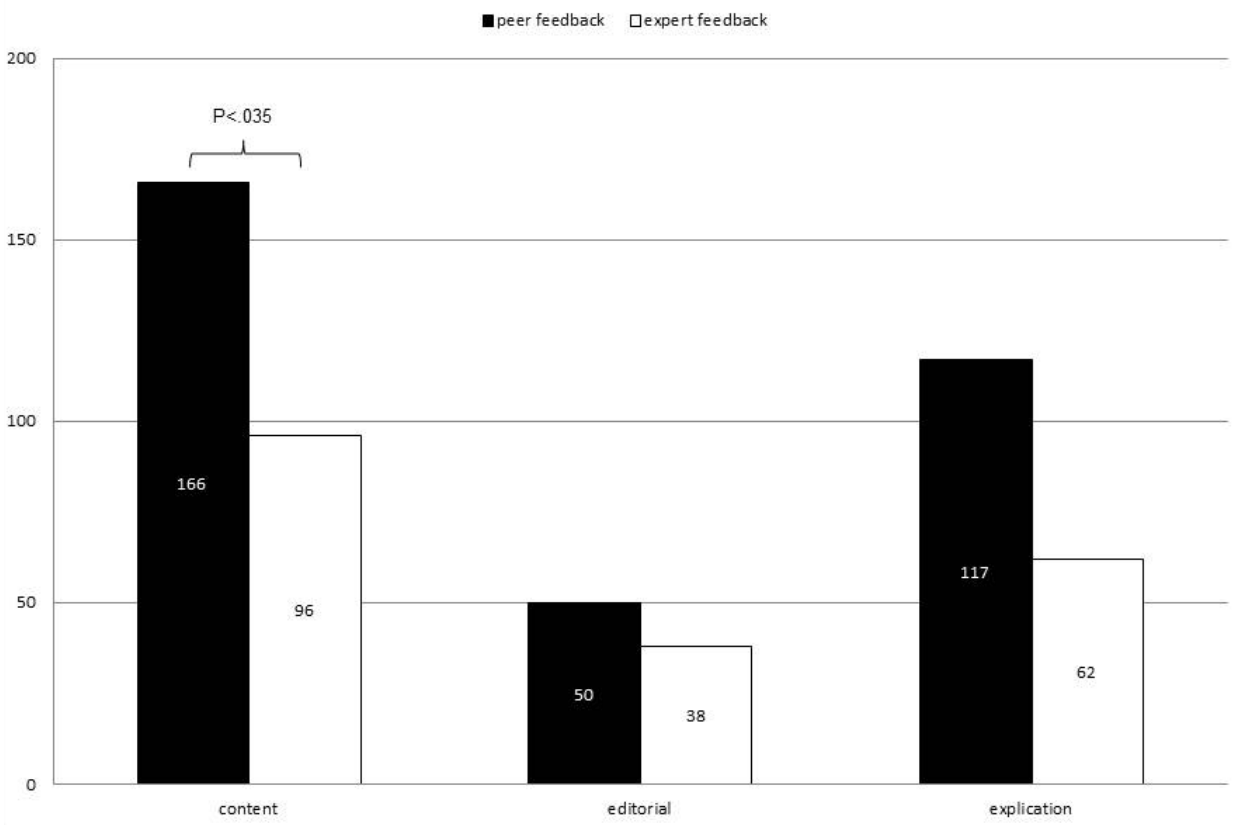

Figure 1 The nature of postings of peer and expert feedback

The following example of peer feedback was categorized as content feedback: "The action to obtain a skin biopsy is still invasive, however significantly less than a kidney biopsy. You write that this is not invasive. However, I think this is still invasive, however probably less invasive. What's your opinion about this?". A sentence as the following was categorized as editorial feedback: "I think it is better to change the title of your research protocol". A typical specification feedback was: "In the summary you describe that some angiogenic factors will be determined. Maybe you can describe these factors already?".

An example of expert feedback that was categorised as content feedback was:" Your research question describes TREC's. However, within the method section I do not recognise TREC's at all. Could you please explain to me why this occurs?", or "Please, explain to me why you use non-invasive biomarkers. What's the use is this in your research?". Expert editorial feedback was typed as: "Your learning goals are not described by the SMART-method. Please adjust", or "use Dutch words, check your text on language errors". Specified expert feedback was exemplified as follows: "I think the question here is which models to predict are of good quality, I think you have to describe more specifically about your own prediction.", or "I think that your hypotheses can be and have to be described much more specific". 


\section{CHAPTER 5}

Figure 2 presents the results on the type of content postings of peer and expert feedback. With exception of non-directive and summary feedback, peers provided more postings on every type of content feedback. Peers sent significantly more criticism $(p=.000)$, praise $(p=.000)$ and off-task comments $(p<.001)$, where experts specifically sent more non-directive comments $(p=.000)$.

\section{Type of content postings}

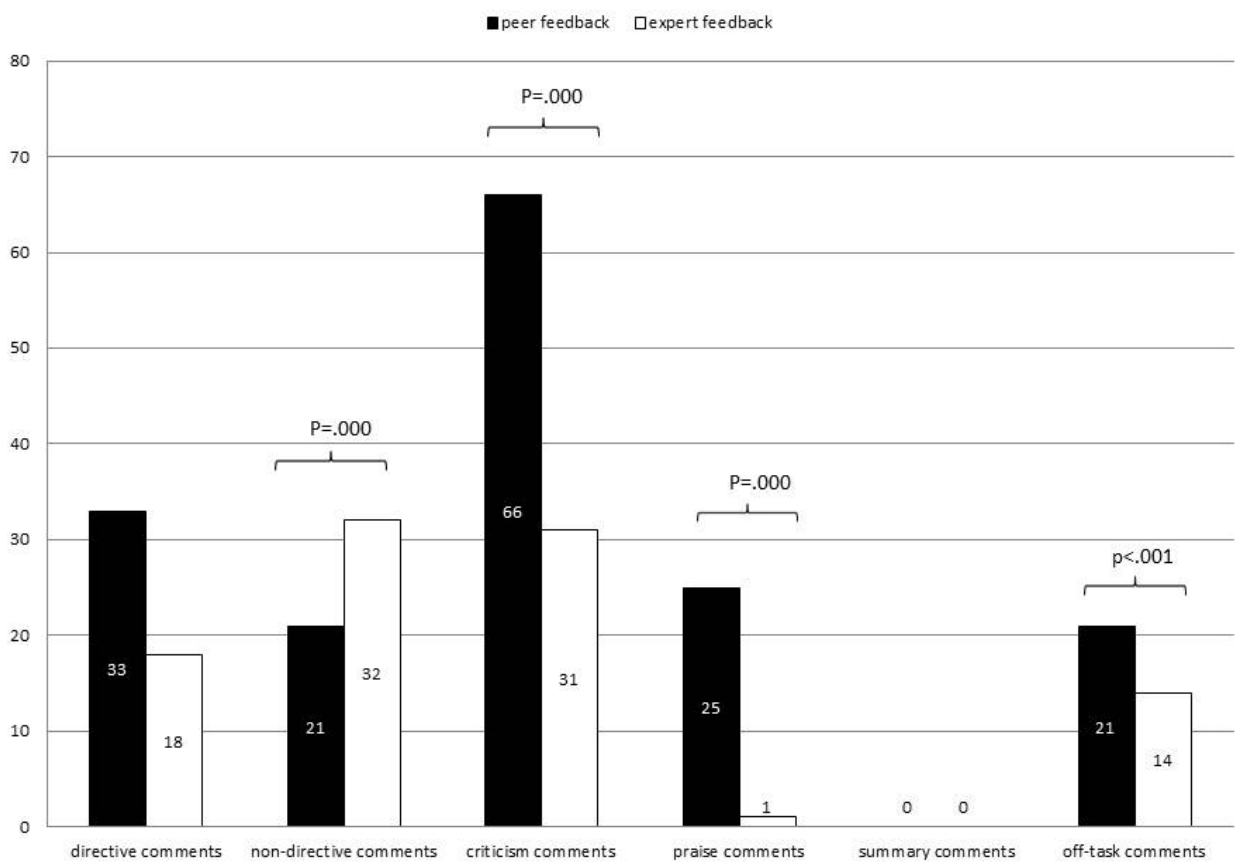

Figure 2 The type of content postings of peer and expert feedback

\section{The review process}

As described in the methods section, there were six review processes a protocol could possibly go through. Figure 3 details the number of protocols, overall and per topic, in each of these processes, with Figure 3 a displaying the review processes that were profitable and Figure $3 \mathrm{~b}$ presenting those that were not.

A total number of 32 protocols (70\%) were classified into the profitable review processes 2, 4, and 6. All of these protocols did not receive expert feedback. Within this group, $4 \%$ of the protocols could be linked to process 2 , whilst $18 \%$ pertained to process 4 , and $48 \%$ could be associated with process 6 . The review processes 1,3 , and 5 that were unprofitable, on the other hand, were allocated a total of 14 (30\%) protocols. All of these protocols received expert feedback. 
Among these protocols, $9 \%$ were classified into process 1, i.e., where peer feedback and revision occurred; $12 \%$ underwent process 3 , in which the protocol remained unrevised after peer feedback was provided; and 9\% were grouped into process 5 in which peer feedback and revision were absent.

Figure 3a. profitable review processes

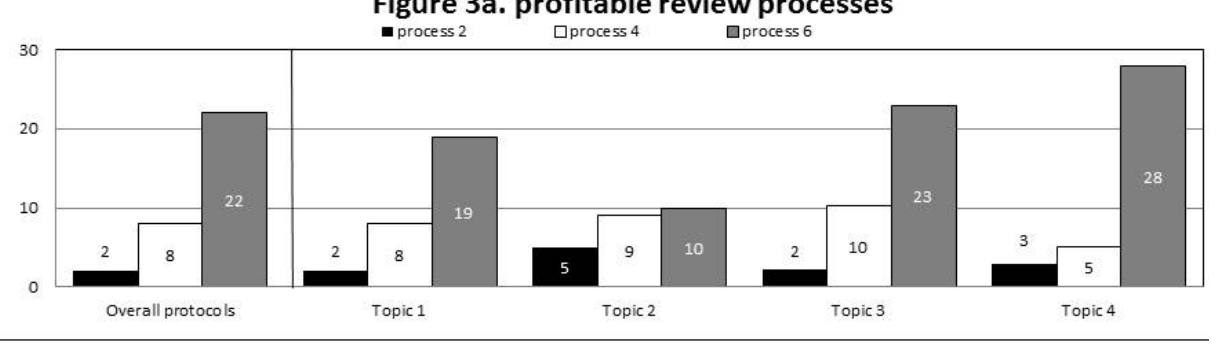

Figure 3b. unprofitable review processes

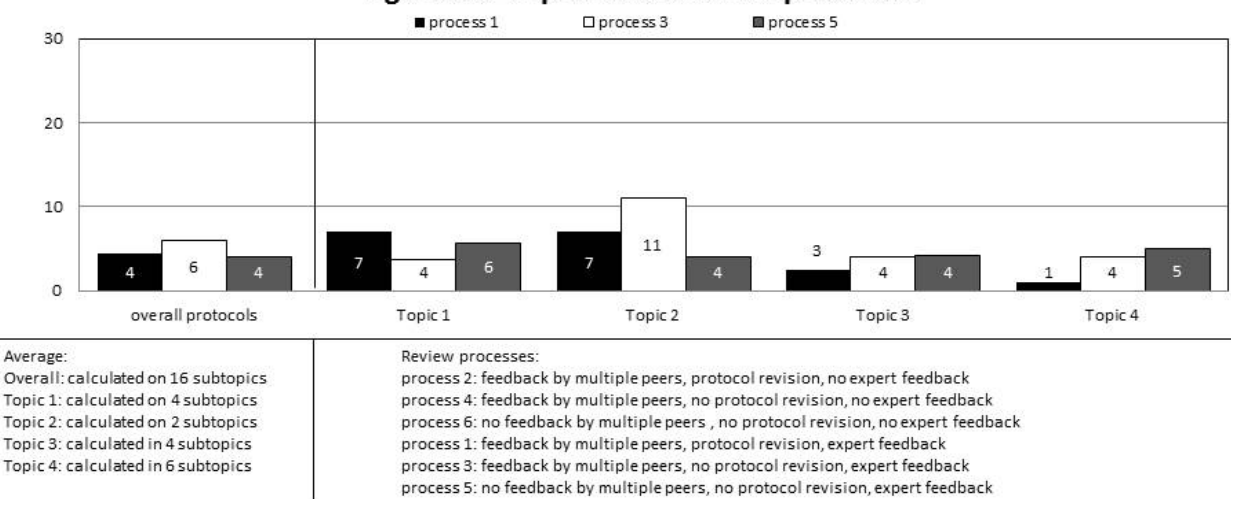

Figure 3 Amount of protocols per review process, overall and differentiated per topic

Phase 1: Feedback by multiple peers

Figure 4 shows the volume of feedback that multiple peers provided on the content of all research protocols, with the black bars on the left representing the numbers of protocols that received feedback and the white bars on the right reflecting those that did not. The overall number of protocols that received feedback totaled 18 (39\%). More specifically, 21 protocols (46\%) received feedback on topic 1; 32 (70\%) protocols received comments on topic 2, whereas 18 (39\%) and 12 protocols (26\%) received feedback on topic 3 and 4 respectively. The number of protocols that received peer feedback was significantly smaller than the number of protocols that did not, both with respect to those receiving feedback on all topics (16 subtopics), and with respect to topic 4 viewed in isolation (based upon 6 subtopics). 


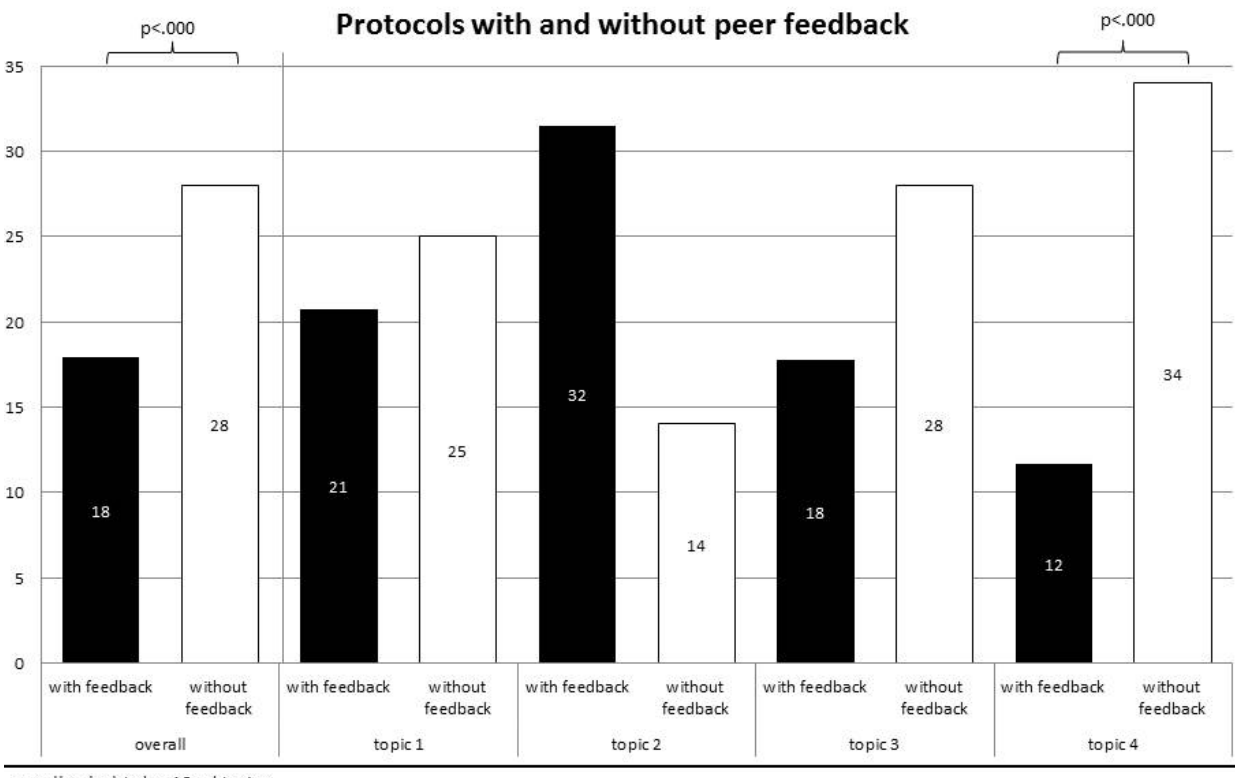

overall: calculated on 16 subtopics

topic 1: calculated on 4 subtopics

topic 2: calculated on 2 subtopics

topic 3 : calculated on 4 subtopics

topic 4: calculated on 6 subtopics

Figure 4 The amount of protocols with and without feedback by multiple peers

\section{Phase 2: Protocol revision}

The protocols that received peer feedback were classified into revised and unrevised protocols. The respective numbers of protocols are presented in Figure 5. Overall, 6 protocols (33\%) were revised in response to peer feedback. More precisely, 9 protocols (43\%) saw a revision of topic 1 and 12 protocols (38\%) of topic 2. In 5 (28\%) and 4 (33\%) protocols revision ensued from peer feedback on topic 3 and 4 respectively. The differences found in numbers of protocols that were revised or not after peer feedback, were not significant. 


\section{Number of revised and unrevised protocols after receiving peer feedback}

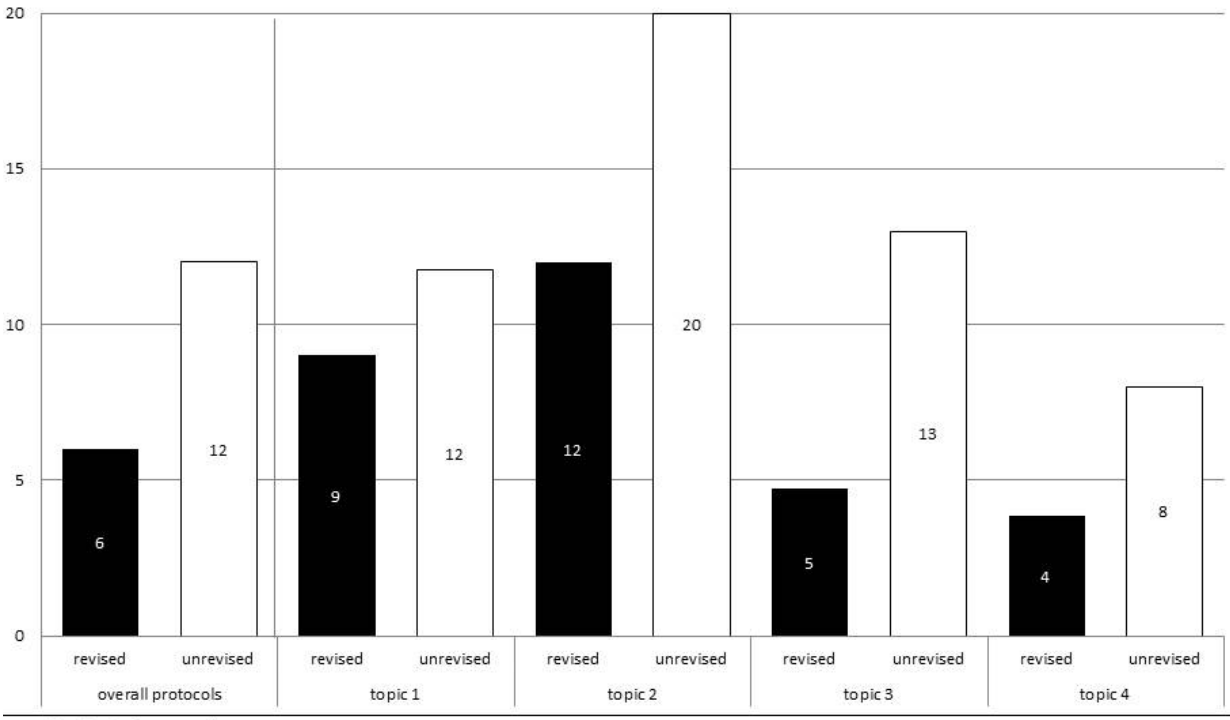

overall: calculated on 16 subtopics

topic 1: calculated on 4 subtopics

topic 2: calculated on 2 subtopics

topic 3 : calculated on 4 subtopics

topic 4: calculated on 6 subtopics

Figure 5 Number of revised and unrevised protocols after receiving peer feedback, overall and per topic

\section{Phase 3: Expert feedback}

Figure 6 presents the numbers of revised and unrevised protocols that received expert feedback on the content of the research protocol. Overall, 14 protocols received expert feedback, 4 (29\%) of which had been revised before. Of the protocols that had seen previous revision, 7 (41\%) were provided with expert feedback on topic 1, again 7 (32\%) received expert feedback on topic 2, whilst $3(27 \%)$ and $1(10 \%)$ protocols still required expert feedback on topic 3 and 4 respectively. On the whole, significantly more unrevised protocols received expert feedback than revised protocols. 


\section{Research protocols with expert feedback}

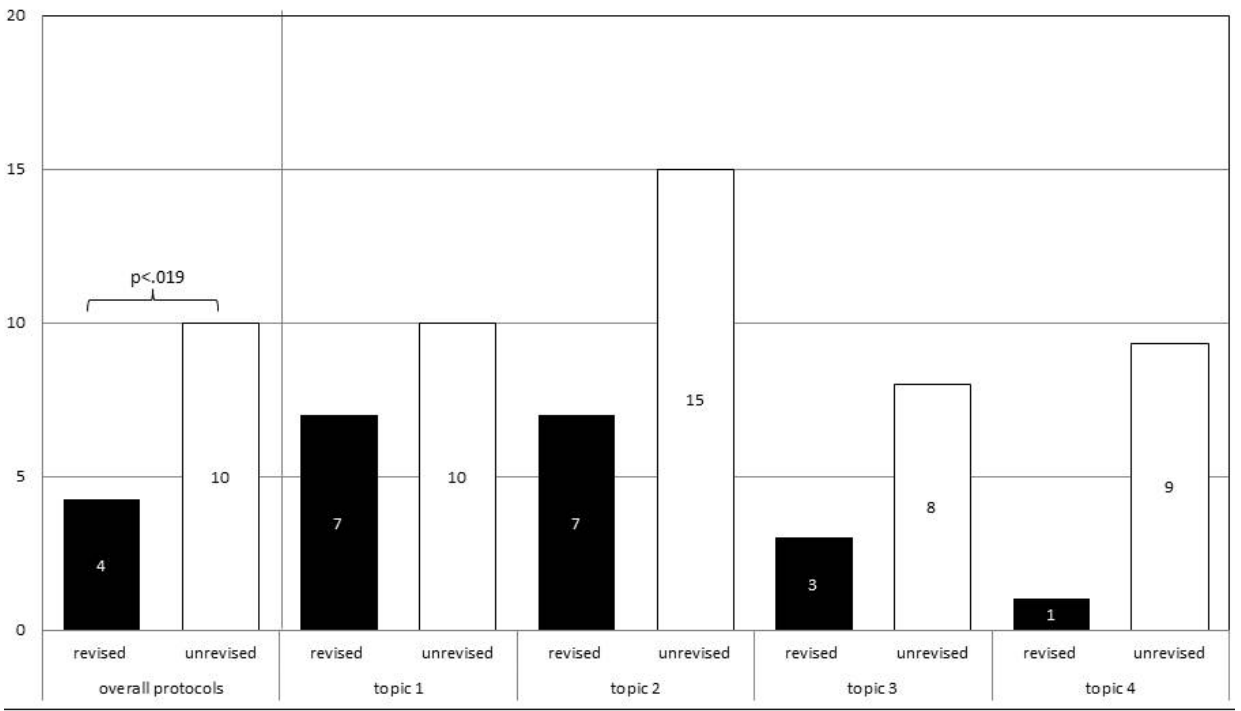

overall: calculated on 16 subtopics

topic 1: calculated on 4 subtopics

topic 2: calculated on 2 subtopics

topic 3 : calculated on 4 subtopics

topic 4: calculated on 6 subtopics

Figure 6 The number of revised and unrevised protocols provided with expert feedback

\section{DISCUSSION}

The results of the present study provide solid evidence that feedback by multiple peers is a valuable educational tool which can be easily wielded by means of an asynchronous discussion forum in a CSCL environment. Regarding the nature of peer feedback, peers provide more feedback during discussion than experts afterwards. Peers exchange significantly more feedback on the content of a protocol than on editorial and specification aspects. Experts deliver less postings than peers but they do not differ that much from their peer counterparts in the kind of nature they provide. Considering the type of feedback we found that students receive significantly more criticism comments, praise and off-task comments from their peers than their experts. Overall, students consider peer feedback as valuable; exploration of the review process shows that a high number (89\%) of participants provide useful peer feedback. One third of students' protocols that receives peer feedback is decided to be revised afterwards.

After peer feedback has been processed and, when applicable, protocols had been revised, the quality of the final student protocols was such that $70 \%$ requires no further expert feedback. Students revealed themselves willing to engage in a process of intense discussion with peers, not only about their own protocols, but also regarding those of their peers. 
Moreover, the fact that in some cases substantial revision of all four topics and related subtopics ensues from peer feedback, indicates that students appreciate it highly. Our results provide strong evidence for Cho and colleagues' (Cho et al. 2006) contention that critical and constructive reflection by peers upon the work of fellow students effectively helps to improve the final quality of written tasks. In this, a CSCL environment acts as a catalyst of students' reflection as it incentivizes them to write down their ideas, thoughts and additional explanations (Stahl 2003; Mahdizadeh 2007).

Yet, task revision not automatically ensues from peer feedback. The extent to which the feedback is perceived as helpful can be one of the factors influencing the decision to revise or not. Peer feedback of low quality or a perceived low value of peer feedback can be a reason not to revise. Previous research has shown that students underestimate the capability of a peer to provide good-quality feedback and that they consider peer feedback as less effective than expert feedback (Cho et al. 2006; Topping 1998). When students have a negative perception of peer feedback they are not willing to revise their task accordingly (Rucker et al. 2003; Atwater et al. 2000). All things considered, the process of peer feedback does seem to offer advantages, especially since revised tasks receive less expert feedback than unrevised tasks. This leads us to conclude that task revision ensuing from peer feedback reduces the need for expert feedback, which confirms earlier findings that peer feedback can be an alternative or valuable addition to expert feedback (Cho et al. 2010).

The present study is not without limitations. For instance, the design of this study does not include a control group: all students had to execute the task and to participate in the discussions. Under the given circumstances in which we did not know what effect the discussion would bring, we wanted all students to provide peer feedback and give them the opportunity to revise their protocol. A second limitation is that we cannot exclude that there were other variables at play that influence the decision for protocol revision. For instance, there were discussion groups in which some students did not actively participate in the discussion, which may have adversely affected the quality of the discussions and, with that, the tendency to revise. Although the majority of students applied much effort to the discussions and contributed well, not all discussions resulted in protocol revision. The reason for this is that students provided a high amount of critical comments during discussion. Other research demonstrated that the feedback type 'Criticism comments' and 'off-task comments' do not necessarily lead to revision and eventually even result in less inspired written tasks (Cho et al. 2006). Another reason could be that students sometimes did not concur with the feedback from their peers or did not fully appreciate it. Similarly, we cannot exclude that some protocols were of such high quality that revision was not needed altogether; students who wrote highquality protocols may, with their advanced contributions to the discussions, have stimulated the knowledge construction of their peers.

The present study raises several questions. First, the students who participate in this research are little seasoned as to how effective feedback should be provided. 


\section{CHAPTER 5}

A study with students receiving effective feedback training before, could yield even better results than those obtained in the present investigation. Secondly, we observe that students differ considerably in their motivation to participate in an asynchronous discussion forum in a CSCL environment on the work of fellow students. Future research on varying patterns of participation could shed some light on how students can be motivated to participate. This may bolster the overall quality of an asynchronous discussion forum in a CSCL environment and task improvement as well.

\section{CONCLUSION}

In a process in which a complex task is reviewed by students within a computer supported collaborative learning environment they make significant contributions. Feedback by multiple peers is an effective instrument to help students revise a written task. Experts mostly provide feedback on tasks that stayed unrevised after peer discussion within a computer supported collaborative learning environment. Trivial comments in peer feedback do not obstruct medical students' asynchronous discussions and the task revision ensuing from them. 


\section{REFERENCES}

- $\quad$ Atwater, L., Waldman, D., Atwater, D. \& Carter, P. An upward feedback field experiment: supervisors' cynicism, reactions, and commitment to subordinates. Personnel Psychology. 2000; 53,275-297.

- $\quad$ Baker, M., Andriessen, J., Lund, K., Amelsvoort, van, M., Quignard, M. Rainbow: A framework for analyzing computer-mediated pedagogical debates. Computer-Supported Collaborative Learning. 2007; 2,315-357. DOI: 10.1007/s11412-007-9022-4.

- Beason, L. Feedback and revision in writing across the curriculum classes. Research in the Teaching of English. 1993; 27,e395-421.

- Biemans, H. Fostering activation of prior knowledge and conceptual change. Doctoral dissertation. 1997, University of Nijmegen, The Netherlands.

- Cho, K., Schunn, C., Charney, D. Commenting on writing: typology and perceived helpfulness of comments from novice peer reviewers and subject matter experts. Written communication. 2006; 23, 260. DOI: 10.1177/0741088306289261

- Cho, K., MacArthur, C. Student revision with peer and expert reviewing. Learning and instruction. 2010; 20, 328-338. DOI:10.1016/j.learninstruc.2009.08.006

- Davis J, Crabb S, Rogers E, Zamora J, Khan K. Computer-based teaching is as good as face to face lecturebased teaching of evidence based medicine: a randomized controlled trial. Medical Teacher. 2008; 20,302-307. DOI: 10.1080/01421590701784349

- De Wever, B., Van Winckel, M., Valcke, M. Discussing patient management online: The impact of roles on knowledge construction for students interning at the pediatric ward. Advances in Health Sciences Education. 2006(a); 13(1), 25-42. DOI: 10.1007/s10459-006-9022-6

- Dillenbourg, P., Järvelä, S., Fischer, F. The evolution of research on computer-supported collaborative learning. From design to orchestration. In: Ludvigsen, S., de Jong, T., Lazonder, A., Barnes, S. (eds) Technology-enhanced learning: principles and products. 2009. Springer Science \& Business Media B.V. DOI: 10.1007/978-1-4020-9827-7_1

- $\quad$ Koops W., Van der Vleuten C., De Leng B., Oei S., Snoeckx L. Computer-supported collaborative learning in the medical workplace: Students' experiences on formative peer feedback of a critical appraisal of a topic paper. Medical Teacher. 2011;33:6:e318-323. DOI: 10.3109/0142159X.2011.575901

- Koops W., Van der Vleuten C., De Leng B., Snoeckx L. Computer supported collaborative learning in a clerkship: an exploratory study on the relation of discussion activity and revision of critical appraisal papers. BMC Medical Education. 2012; 12,79. DOI:10.1186/1472-6920-12-79.

- Koops W., Van der Vleuten C., De Leng B., Houterman, S. \& Snoeckx L. Computer-supported collaborative learning at the clinical workplace: students' perceptions and the effect of knowledge construction on learning outcome. International Journal of Contemporary Medical Education. 2014; 2,71-78. DOI: 10.5455/jcme.20140118055300.

- Kreijns, K., Kirschner, P. \& Jochems, W. The Sociability of Computer-Supported Collaborative Learning Environments. Educational Technology \& Society. 2002; 5,8-22. ISSN 1436-4522

- Kreijns, K., Kirschner, P. \& Jochems, W. Identifying the pitfalls for social interaction in computersupported collaborative learning environments: a review of the research. Computers in Human Behavior. 2003; 19,335-353. PII: S0747-5632(02)00057-2

- Kreijns, K., Kirschner, P., Jochems, W., Van Buuren, H. Measuring perceived sociability of computersupported collaborative learning environments. Computers \& Education. 2005; 49,176-192. DOI: 10.1016/j.compedu.2005.05.004

- Mahdizadeh, H. Student collaboration and learning. Knowledge construction and participation in an asynchronous computer-supported collaborative learning environment in higher education, doctoral dissertation, 2007. Wageningen university, the Netherlands.

- Medélez E, Burgun A, Le Duff F, Le Beux P. Design of a CSCL Environment for Clinical Reasoning Learning and Problem-Based Learning in Medicine. In: Patel, V., Rogers, R., Haux, R. (ed.) Studies in Health Technology and Informatics. 2001. MedInfo, IOS Press. 


\section{ChAPTER 5}

- $\quad$ Rourke, L., Anderson, T., Garrison, D., Archer, W. Methodological Issues in the Content Analysis of Computer Conference Transcripts International Journal of Artificial Intelligence in Education. 2001; 12,1. DOI:10.1152/advan.00026.2004.

- Rucker, M. , Thompson, S. Assessing student learning outcomes: An investigation of the relationship among feedback measures. College Student Journal. 2003; 37(3),400-404. ISSN: 0146-3934.

- Schellens, T. Valcke, M. Collaborative learning in asynchronous discussion groups: What about the impact on cognitive processing? Computers in Human Behavior. 2005; 21, 957-975. DOI: 10.1016/j.chb. 2004.02.025.

- Stahl, G. Meaning and interpretation in collaboration. In B. Wasson, S. Ludvigsen \& U. Hoppe (ed) Designing for change in networked learning environments: Proceedings of the international conference on computer support for collaborative learning. CSCL '03, Bergen, Norway, Kluwer Publishers. 2003; 523-532.

- Strijbos, J., Narciss, S., Dünnebier, K. Peer feedback content and sender's competence level in academic writing revision tasks: are they critical for feedback perceptions and efficiency? Learning and Instruction. 2010; 20,e291-e303. DOI:10.1016/j.learninstruc.2009.08.008

- Topping, K. Peer assessment between students in colleges and universities. Review of Educational Research. 1998; 68(3),249-276.

- Van Bruggen, J., Kirschner, P., Jochems, W. External representation of argumentation in CSCL and the management of cognitive load. Learning and Instruction. 2002; 12, 121-138.

- Vedder, P. Cooperative learning: A study on processes and effects of cooperation between primary school children. 1985. Groningen University, The Netherlands.

- Veldhuis-Diermanse, A. E. CSCLearning? Participation, learning activities and knowledge construction in computer-supported collaborative learning in higher education, Doctoral dissertation, 2002. Wageningen University, the Netherlands.

- Wang, A., Newlin, M. Characteristics of students who enroll and succeed in psychology web-based classes. Journal of educational psychology. 2000; 92(1), 137-143. DOI: 10.1037//0022-0663.92.1.137.

- Watling, C., Driessen, E., van der Vleuten, C., Lingard, L. Learning from clinical work: the roles of learning cues and credibility judgements. Medical education. 2012; 46,192-200. DOI:10.1111/j.13652923.2011.04126.x 

The present dissertation describes the results of various studies on the collaborative learning activity of clinical clerkship students via an asynchronous discussion forum in a Computer-Supported Collaborative Learning (CSCL) environment. This last chapter discusses the main findings that answered the research questions and consequently describes the implications for education. The final sections present the strengths and limitations of this dissertation and highlight a few directions for future research.

\section{DISCUSSION OF THE MAIN FINDINGS}

The findings of this dissertation indicate that an asynchronous discussion forum facilitated via a CSCL environment contributes positively to the learning process of clinical clerkship students.

First, we investigated how these students interact and how they perceive the instructional quality of the asynchronous discussion of an authentic task in a CSCL environment during their clinical clerkship. Previous research has demonstrated that a positive perception by its students enhances the effectiveness of an instructional intervention (Dewiyanti, 2005; Mahdizadeh, 2007; Laurillard, 2002; Morrison et al., 2004). Since time management plays a key role in clinical clerkships (Prince, 2000), making it difficult to organise synchronous discussions, asynchronous discussions can motivate students to participate more frequently by allowing them to perform the discussion task at their convenience (De Wever, 2006c, Dewiyanti, 2005; Van Der Meijden, 2005; VeldhuisDiermanse, 2002; Mahdizadeh, 2007). Our four studies revealed that clerkship students are very willing to interact actively in an asynchronous discussion during clinical workplace learning, as evidenced by a participation rate that ranged between 86 and 100\%. Hence, we observed that clerkship students do well on the 'participation' factor (chapters 2 and 3) which observation was supported by the many postings with relevant feedback denoting a high level of interaction. The present dissertation clearly demonstrates that student's involvement in an asynchronous discussion in a CSCL environment leads to enhanced knowledge construction and improved tasks (chapters 2, 3 and 4).

Second, we explored medical students' perceptions of knowledge improvement (learning outcome) after they performed a task on work-based experiences on an asynchronous discussion forum in a CSCL environment and compared these with the results from an objective measurement of knowledge improvement. Although medical students generally felt they had improved their knowledge as a result of the discussion (chapters 2 and 3), this was not reflected in the marks experts awarded to the tasks that had been revised after the discussion (chapter 3 ). Instead, we identified a discrepancy between experts' marks and students' subjective perception of knowledge improvement (chapter 3).

The marks allocated by experts did not point to an improvement in the quality of task revisions that ensued from peer discussions. 
More specifically, experts' marks for revised tasks were not higher than those for unrevised tasks. In education, expert marks for a task are considered objective and relevant, and students generally accept them as an appreciation of the task's quality (Schilling, 2006; Shah, 2008; Raupach, 2010; Dewiyanti, 2005; Williams, 2001; Taradi et al., 2004; Wiecha, 2006; Kamin, 2002; Taradi, 2005; Heath, 2008; Servais et al., 2006; Bernardo, 2004; Bowdish, 2003; Raupach, 2009). At the same time, recent studies have demonstrated that specific and relevant feedback can provide a more powerful stimulus to students' learning process than can a simple expert mark, either from experts or otherwise (Sargeant et al., 2010; Leinster, 2009; Scarf et al., 2015). Our results clearly illustrate that feedback from both students and experts gives us a better reflection of the quality of students' activity during the learning process (knowledge construction) and we believe that feedback is a more relevant indicator of knowledge improvement (learning outcome) (chapter 5).

Third, we sought to gauge the extent to which medical students constructed knowledge (learning progress) during an asynchronous discussion in a CSCL environment and how it was affected by the intensity of students' participation. The analysis of students' discussions revealed that the amount and content of the feedback provided correlated positively with the frequency of task revision. We specifically analyzed those discussions that led to revision of tasks and found that these discussions contained a high number of task-oriented postings. Providing structure to the discussion can encourage active student participation in a CSCL environment and increase task-oriented activity (De Wever, 2006c; Dewiyanti, 2005; Van der Meijden, 2005; Mahdizadeh, 2007; Veldhuis-Diermanse, 2002; Baker et al., 1997). To create such structure, a script has been found useful as it can both help structure the discussion task and provide a timeline (Haake, 2010; Pfister et al., 2002). In all the studies of this dissertation, we used scripts to structure discussions, providing guidance to students as to how and in what sequence to perform the task. Hence, the present dissertation lends further credence to previous study findings suggesting that a structured discussion and a script can both bolster student participation in a CSCL environment.

Finally, we investigated the effect of multiple peer feedback, delivered during an asynchronous discussion in a CSCL environment, on the quality of a task. By means of an in-depth analysis of feedback delivered by multiple peers during a discussion in a CSCL environment, we demonstrated that such feedback can, indeed, be useful and efficient. The analysis provided evidence that students are able to detect omissions and provide good-quality feedback regarding aspects of a task that needed revision. When such tasks had been revised as per peer feedback, they received substantially less expert feedback than did unrevised tasks. We also found expert feedback to largely coincide with the feedback provided by multiple peers (chapter 5 ).

Previous research has demonstrated that students often underestimate the capability of a peer to provide good-quality feedback and that they consider peer feedback as less effective than expert feedback (Cho et al., 2006; Topping, 1998). 
Yet, peer feedback can be an alternative or valuable addition to expert feedback (Cho et al., 2010). The present dissertation confirms this, showing that the process of peer feedback does seem to offer advantages, especially since expert feedback mainly focused on tasks that had remained unrevised, despite the fact that the nature of expert feedback did not differ that much from that of peers (chapter 5).

\section{IMPLICATIONS FOR EDUCATION}

The results of this dissertation provide evidence that a structured asynchronous discussion forum in a CSCL environment has the potential to support medical students' learning, especially when such learning is effected in clinical clerkships (chapters 2, 3, 4 and 5). First, we believe that asynchronous discussion of a task, by requiring students to share, discuss and elaborate, offers clinical clerkship students an effective way to learn from peer feedback and, consequently, promotes collaborative learning (chapters 2 and 3). For such discussions to be successful, however, we believe it is important that they be structured in such a way that medical students can successfully complete their task paying heed to each content aspect of the task. Another advantage of providing structure to discussions is that students will not only address individual learning needs, but also be exposed to the collective learning content of the group (chapters 2, 3, 4 and 5). This approach will allow all discussants to keep track of items already discussed and of those remaining. It could well be argued that an asynchronous discussion may be more effective in reaching certain goals within a set time.

Next, it is important that such tasks that are the subject of multiple peer feedback be well-defined, for it helps students to focus strongly on the content of their task (chapters 2, 3, 4 and 5). In the present dissertation, we investigated how clinical clerkship students discussed two different tasks on an asynchronous discussion forum. The first task was a written clinical problem students had encountered in the workplace (chapters 2 and 3), whereas the second tasks concerned a written research proposal outlining the projected clinical research (chapters 4 and 5). Although these two tasks were completely different in nature, the main findings of the four different studies were rather consistent. Since a CSCL environment offers a platform for the discussion of tasks, such as patient cases or reviews, other types of tasks specifically designed for workplace learning (medical or otherwise) could be introduced as well. Moreover, experts can observe the discussion process and make adjustments when needed.

Furthermore, a CSCL environment is a valuable asset to clinical clerkships and will help to overcome the inconvenience of separation in time and place. The medical students who participated in this dissertation's studies were scattered over different workplaces in different hospitals, both within and outside the Netherlands.

We found that student participation in CSCL was not affected by the type of task, group composition or clinical workplace. 
This suggests the practice of collaborative learning via asynchronous discussion in a CSCL environment can be applied to a broad range of clinical workplaces.

Finally, an expert, a teacher for example, can promote the quality of collaborative discussions by encouraging students to believe in the value of feedback from multiple peers (chapters 2, 3, 4 and 5). An expert can also incentivize students to focus on content by giving directions when they tend to go astray, and can encourage them to provide quality feedback on both social and task-related issues. In order to achieve this goal, experts need to be informed of the principles of such a structured asynchronous discussion and their respective role, while both experts and students need to be trained before executing the task.

\section{STRENGTHS AND LIMITATIONS OF THE DISSERTATION}

The present dissertation has several merits that strengthen our conclusions. First, all studies aimed to facilitate collaborative learning by connecting medical students via a digital learning platform, which has proved its robustness. That is, throughout the various studies the computer applications we chose presented no major drawbacks. Second, we designed the various studies in such a way that we could thoroughly analyze the content of asynchronous discussions in a CSCL environment using the validated content-analysis system developed by Baker and colleagues (Baker et al., 2007) for various investigations (chapters 2, 3 and 4). The last few years have witnessed a surge in multiple methods for the analysis of specific elements of CSCL discussion content (De Wever et al., 2006). However, we preferred to use the content-analysis system by Baker and colleagues, because it provided insight into the different levels of students' knowledge construction and, to the best of our knowledge, had not previously been applied in medical education. In this way we gained a better insight into medical student's knowledge construction by collaborative learning in the workplace (Kreijns et al., 2005; Dewiyanti, 2005; Van der Meijden, 2005; De Wever et. al., 2006). The third strength of our dissertation is the high participation rate. In the design phase of our studies, we noted some skepticism about students' motivation to participate in an extra assignment of which the gains would be uncertain, while they were already involved in a fairly demanding clinical clerkship (Prince, 2000). Taken into account that students were free to withdraw their participation at any time, it is a powerful asset of each of the four studies that the participation rate was higher than $86 \%$. On the other hand, however, students participated voluntarily, because of which they may have been more motivated than the average student to actively collaborate during discussions. Besides this, it cannot be excluded that students chose to engage in animated discussions, because of the opportunity to improve their self-selected individual written task with the help of peer feedback, consequent revision, and submission to expert review. We therefore consider it likely that the same will hold true for other tasks that are relevant to clinical workplace learning. 


\section{DIRECTIONS FOR FUTURE RESEARCH}

The present dissertation raises several new questions that could guide future research. The question of how students can be better supported and encouraged to collaborate and construct knowledge during their clinical clerkship has only recently become a focus of attention in research. We suggest that this focus be narrowed down to the influence of an intellectually stimulating task, factors such as motivation and attitude, the role of a moderator, and the degree to which both task and discussion are structured to shed some light on the freedom we should give to students in the discussion to obtain the best levels of knowledge construction (Deci et al., 1985; Rienties, 2009; De Wever et al., 2006a; De Wever et al., 2006b). Next, since student participants in the present dissertation were generally ignorant about how to provide constructive, effective feedback, it could be investigated whether better feedback results would be obtained after receipt of a professional training in providing feedback. Our last recommendation for future research is the most challenging one: research should identify whether a collaborative discussion (about improvement or amendment of a patient guideline, for instance) can effect behavioral change in medical professionals from which patient care could benefit.

\section{CONCLUSIONS}

Based on the results of the present dissertation it can be concluded that CSCL shows promise as a format to facilitate both medical students' provision of formative feedback on each other's written tasks during clinical workplace learning and the revision of such tasks. After participation in an asynchronous forum discussion in a CSCL environment, medical students expressed their appreciation of the project, of its design, and believed their knowledge had improved because of it. Students who felt they had participated actively and had improved their knowledge had indeed been actively engaged in the discussions, as evidenced by the high amount of discussion messages sent. An increase in feedback by multiple peers during the discussions seemed to spark task-focused activities and discussion about the content of the task. Medical students who contributed actively to the asynchronous CSCL discussion revised their written task after the discussion. Trivial comments in peer feedback did not adversely affect medical students' asynchronous discussions and the task revision ensuing from them. Medical students' active engagement in an asynchronous CSCL discussion and subsequent task revision did not necessarily cause experts to award significantly higher marks for the task.

Expert feedback mainly targeted those tasks that had remained unrevised after peer discussion in a computer-supported collaborative learning environment. 


\section{REFERENCES}

- $\quad$ Baker, M., Andriessen, J., Lund, K., Amelsvoort, van, M., Quignard, M. Rainbow: A framework for analyzing computer-mediated pedagogical debates. Computer-Supported Collaborative Learning. 2007; 2,315-357. DOI: 10.1007/s11412-007-9022-4.

- Bernardo , V., Ramosa, M., Plapler, H., de Figueiredo L., Nader, H., Silva Anção, M., von Dietrich, C., Sigulem, D. Web-based learning in undergraduate medical education: development and assessment of an online course on experimental surgery. International Journal of Medical Informatics. 2004; 73,731-742. DOI: 10.1016/j.ijmedinf.2004.06.002.

- Bowdish, B., Chauvin, S., Kreisman, N., Britt, M. Travels towards Problem Based Learning in Medical Education (VPBL). Instructional Science. 2003; 31,231-253.

- Cho, K., Schunn, C., Charney, D. Commenting on writing: typology and perceived helpfulness of comments from novice peer reviewers and subject matter experts. Written communication. 2006; 23, 260. DOI: 10.1177/0741088306289261

- Deci, E., Ryan, R. The General Causality Orientation Scale: Self-determination in personality. Journal of Research in Personality. 1985; 19, 109-134. DOI: 10.1016/0092-6566(85)90023-6

- De Wever, B., Van Winckel, M., Valcke, M. Discussing patient management online: The impact of roles on knowledge construction for students interning at the pediatric ward. Advances in Health Sciences Education. 2006(a); 13(1), 25-42. DOI: 10.1007/s10459-006-9022-6

- De Wever B, Schellens, T., Valcke M. Van Keer, H. Content analysis schemes to analyze transcripts of online asynchronous discussion groups: A review. Computers \& Education 2006(b); 46,6-28. DOI: 10.1016/j.compedu.2005.04.005

- Dewiyanti, S. Learning together: a positive experience. The effect of reflection on group processes in an asynchronous computer-supported collaborative learning environment. Ph.D.-dissertation. 2005. Datawyse Maastricht. ISBN: 90-3582251-X

- Dillenbourg, P., Järvelä, S., Fischer, F. The evolution of research on computer-supported collaborative learning. From design to orchestration. In: Ludvigsen, S., de Jong, T., Lazonder, A., Barnes, S. (ed) Technology-enhanced learning: principles and products. 2009. Springer Science \& Business Media B.V. DOI: 10.1007/978-1-4020-9827-7_1

- Haake J., Pfister H. Scripting a distance-learning university course: Do students benefit from net-based scripted collaboration? Computer-supported Collaborative Learning. 2010;.5,191-201. DOI 10.1007/s11412-010-9083-7.

- Heath, S., Higgs, J., Ambruso, D. Evidence of knowledge acquisition in a cognitive flexibility-based computer learning environment. Medical Education Online. 2008; 13,16. DOI:10.3885/meo.2008. Res00261

- Kamin, C., O'Sullivan, P., Deterding, R. Does project L.I.V.E. Case Modality impact critical thinking in PBL groups? Paper presented at the annual meeting of the American Educational Research Association, 2002. New Orleans, LA.

- Kreijns, K., Kirschner, P., Jochems, W., Van Buuren, H. Measuring perceived sociability of computersupported collaborative learning environments. Computers \& Education. 2005; 49,176-192. DOI: 10.1016/j.compedu.2005.05.004

- Leinster, S. Workplace-based assessment as an educational tool: Guide Supplement 31.2 - Viewpoint. Medical Teacher. 2009; 31,1032. DOI: 10.3109/01421590902832996

- Pfister H., Mühlpfordt, M. Supporting discourse in a synchronous learning environment: The learning protocol approach. In Stahl, G. (ed.) Computer support for collaborative learning: Foundations for a CSCL community. Proceedings of CSCL 2002 Hillsdale: Erlbaum.

- Prince, C., Van de Wiel, M., Scherpbier, A., Van der Vleuten, C.,Boshuizen, H. A qualitative analysis of the transition from theory to practice in undergraduate training in a PBL-medical school. Advances in Health Sciences Education. 2000; 5(2),105-110. 


\section{ChAPTER 6}

- $\quad$ Raupach, T., Muenscher, C., Anders, S., Steinbach, R., Pukrop, T., Hege, I., Tullius, M. Web-based collaborative training of clinical reasoning: A randomized trial. 2009; 31,e431-e437. DOI: 10.1080/01421 590903095502

- $\quad$ Raupach, T., Münscher, C., Pukrop, T., Anders, S., Harendza, S. Significant increase in factual knowledge with web-assisted problem-based learning as part of an undergraduate cardio-respiratory curriculum. Advances in Health Science Education. 2010; 15,349-356. DOI: 10.1007/s10459-009-9201-3

- Rienties, B., Tempelaar, D. T., Van den Bossche, P., Gijselaers, W. H., \& Segers, M.. The role of academic motivation in Computer-Supported Collaborative Learning. Computers in Human Behavior, 2009; 25(6), 1195-1206.

- $\quad$ Rourke, L., Anderson, T., Garrison, D., Archer, W. Methodological Issues in the Content Analysis of Computer Conference Transcripts International Journal of Artificial Intelligence in Education. 2001; 12,1. DOI:10.1152/advan.00026.2004.

- Sargeant, J., Armson, H., Chesluk, B., Dornan, T., Eva, K., Holmboe, E. The processes and dimensions of informed self-assessment: a conceptual model. Academic Medicine. 2010; 85(7),1212-1220.

- Scarf C., Bearman, M., Corderoy R.M. Supervisor perspectives on the summative in-training assessment. Australasian journal of dermatology 2015. DOI: 10.1111/ajd.12376.

- Schellens, T. Valcke, M.. Collaborative learning in asynchronous discussion groups: What about the impact on cognitive processing? Computers in Human Behavior. 2005; 21,957-975. DOI: 10.1016/j.chb.2004. 02.025

- Schilling, K., Wiecha, J., Polineni, D., Khalil, S. An interactive web-based curriculum on evidence-based medicine: design and effectiveness. Family Medicine. 2006; 38(2),126-132.

- $\quad$ Servais E., LaMorte, W., Agarwal, S., Moschetti, W., Malliputti, S., Moulton, S. Teaching surgical decisionmaking: An interactive, web-based approach. Journal of surgical research. 2006; 134,102-106. DOI:10.1016/j.jss.2005.11.583

- Shah,I., Walters, M., McKillop, J.. Acute medicine teaching in an undergraduate medical curriculum: a blended learning approach. Emergency Medicine Journal. 2008; 25,354-357. DOI:10.1136/emj.2007. 053082

- Taradi, S., Taradi, M. Expanding the traditional physiology class with asynchronous online discussions and collaborative projects. Advances in Physiology Education 2004; 28,73-78. DOI:10.1152/advan.00017.2003

- Taradi S.K., Taradi, M., Radic, K., Pokrajac, N. Blending problem-based learning with Web technology positively impacts student learning outcomes in acid-base physiology. Advanced Physiological Education. 2005; 29,35-39. DOI:10.1152/advan.00026.2004.

- Van der Meijden, H. (2005). Knowledge construction through CSCL: Student elaborations in synchronous, asynchronous and 3-D learning environments. Drukkerij Tamminga, Duiven, The Netherlands. ISBN10:9090197184.

- Wang, A., Newlin, M. Characteristics of students who enrol and succeed in psychology web-based classes. Journal of educational psychology. 2000; 92(1), 137-143. DOI: 10.1037//0022-0663.92.1.137.

- Wiecha, J., Chetty, V., Pollard, T., Shaw, P. Web-based Versus Face-to-Face Learning of Diabetes Management: The Results of a Comparative Trial of Educational Methods. Family Medicine. 2006; 38(9),647-52.

- Williams, C., Aubin, S., Harkin, P., Cottrell, D. A randomized, controlled, single-blind trial of teaching provided by a computer-based multimedia package versus lecture. Medical Education. 2001; 35(35),847-854. 


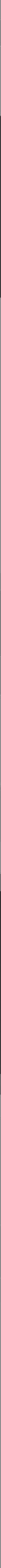


Chapter 1 addresses the introduction, the aim and the general research question of this dissertation. In the last decades the view on learning and instruction in higher education has changed radically. Traditional teacher-centered learning activities have been gradually substituted by more student-centered learning activities based on the view that students are perfectly capable to self-direct their learning. This approach is derived from the educational theory of constructivism that focuses on a dynamic and studentcentered learning process where students actively construct knowledge. Knowledge construction contains several activities: 1) the complementation, elaboration and evaluation of ideas, 2) summarizing and evaluation of externally acquired information, and 3) connecting a variety of facts, new ideas or concepts with the present knowledge of the individual student. Where constructivism considers knowledge construction as an individual process that takes places internally by a student, social-constructivism considers knowledge construction as social process that, for a part is executed externally; outside of students' thoughts. By learning in a social context students are stimulated to play a larger and more active collaborative role in their own learning process and in that of their peers.

In a specific learning environment such as work-based learning collaborative learning is potentially valuable because students encounter several experiences that are real and relevant to them as well as to their peers. By enabling students to share these experiences and to use them to learn, they can profit from collaborative learning. However, during work-based learning students are often physically dispersed in time and place and therefore it is hard to organize collaborative learning efficiently. In order to create an additional value to collaborative learning within workplace learning, the introduction and use of a computer supported collaborative learning ( $\mathrm{CSCL}$ ) environment can be very beneficial. In fact, CSCL facilitates social interaction via a structured (asynchronous) peer discussion between group members. As such students are able to provide effective feedback on learning tasks of one or more peers.

At present, providing peer feedback on a learning task is not common in medical education. Workplace learning comprises a significant portion of medical education in which students learn mostly individually from encountered work-based experiences. These experiences are clinical problems that are real and relevant to them as well as to their peers. Under such circumstances learning collaboratively could offer an additional value to stimulate knowledge construction. Medical students can learn collaboratively by actively discussing work-based experiences with the use of a CSCL environment, even when they are scattered over different clerkships, hospitals and countries. As such, the principal question of this dissertation is: "does an asynchronous discussion in a CSCL environment positively contributes to the learning process of medical students conducting a clinical clerkship?". The relevance of this dissertation lies in the justification (chapter 2 and 3) and the clarification (chapter 4 and 5) of how medical students learn collaboratively on a task while conducting an individual clinical clerkship. 
Chapter 2 describes the results of an study with a mixed method design to explore whether a structured asynchronous discussion on an authentic task within a CSCL environment have additional value for learning in the clinical workplace. Students' perceptions of the CSCL arrangement were questioned (by a questionnaire and a semistructured interview) with respect of their preparation and participation, forum design and perceived knowledge improvement. Discussion postings were analyzed to explore how students interact during a CSCL discussion. The students considered a preparation to the discussion to be necessary and perceived knowledge improvement of their tasks. The content of students' discussions was mostly task-focused. The quantity of sent postings and degree of activity in the discussion seem to positively affect the perceptions: Participation and Knowledge improvement. These results suggest that CSCL appears to offer a suitable learning environment enabling students to collaborate in asynchronous discussions, and in which they provide formative feedback on a relevant workplace task.

Chapter 3 presents the findings of an experimental study on medical students' knowledge construction during an asynchronous CSCL discussion on a relevant workplace task. After the discussion students were allowed to revise their written task before submitting it for final expert grading. Aside from that, students' perceptions preparation, design, participation and knowledge improvement were explored by a questionnaire and a semi-structured interview. Students' discussion postings were analyzed on content, while the quality of the tasks was independently marked by two experts (experienced staff-members). Questionnaire items showed positive student perceptions while interview items revealed both positive and negative perceptions. Content-analysis of postings showed a significantly higher level of knowledge construction in the discussions that led to task revision. No significant differences in expert grading were found between the tasks before discussion and after revision. We conclude that medical students show positive subjective perceptions on a structured asynchronous discussion of their tasks. Students revising their task after an asynchronous CSCL discussion show a significant higher active knowledge construction than peers who do not revise their task. However, active knowledge construction is not necessarily paralleled by a significantly higher expert grading.

Chapter 4 describes a study that examines in more detail whether medical students who revise a relevant workplace task after participating in a structured asynchronous discussion within a CSCL environment, discuss more intensively and attain higher levels of knowledge construction than students who do not revise their tasks. To this end, discussion postings were analyzed on content and categorized into a level of knowledge construction. Furthermore, discussion postings were assigned to specific topics of a task.

It was found that the revision of tasks was associated with significantly higher numbers of discussion postings, higher task-focused activity, and discussion of specific topics of a task. 
We conclude that a CSCL environment supports medical students to execute a relevant task encountered during work-based learning. An increase in activity during the discussions is positively related to a high amount of task-focused activities and more discussion on specific topics of a task.

Chapter 5 presents a study on the effect of feedback by multiple peers provided in an asynchronous discussion on a task within a CSCL environment while conducting a clerkship. In a detailed design, three phases of a task review process were explored: 1) feedback on the task by multiple peers on a forum of a $\mathrm{CSCL}$ environment, 2) task revision ensuing from feedback by multiple peers, and 3) expert feedback on the task afterwards. The outcome of the review process was considered profitable if expert feedback was not forthcoming, whereas the opposite was true when expert feedback did ensue. Both the volume and type of peer and expert feedback were analyzed. Feedback by multiple peers was delivered on $39 \%$ of the tasks, one third of which were revised accordingly. Experts delivered feedback on $30 \%$ of the finally submitted tasks. From these tasks, it was proven that $71 \%$ had remained unrevised after peer discussion. Peers and experts largely attached similar weights to the various task topics. Experts did not differ in the type of feedback they provided on revised and unrevised tasks, whereas peers provided significantly more trivial comments on tasks that remained unrevised after discussion. It was concluded that in a process in which a complex task is reviewed, students make significant contributions. Feedback by multiple peers is an effective instrument to help students revise a written task. Cutting back on trivial comments in peer feedback could enhance students' discussions and the task revision ensuing from them. Experts mostly provide feedback on tasks that were not revised, where the majority of the tasks do not require expert feedback at all, regardless of whether or not they had been revised previously

Chapter 6 discusses the main findings on the research questions of this dissertation and presents the implications for education. Furthermore, the strengths and limitations of this dissertation are described and a few directions for future research are highlighted. This chapter ends by presenting the main conclusion of this dissertation.

The main findings that are discussed are 1) students' high participation rate, and positive perceptions that enhances knowledge construction and task improvement, 2) the discrepancy between expert marks and students' positive perception on knowledge improvement, and feedback as a relevant indicator of knowledge improvement, 3) the positive effect of a structured discussion and a script to students level of knowledge construction, and 4) the profit of multiple-peer feedback to the quality of a task and the effect of this on expert feedback.

The main implication to education is that a structured asynchronous discussion within a CSCL environment has a potential value to support medical students' learning conducting their task, especially in a specific learning environment such as a clinical clerkship. 
The strengths of this dissertation is that it concentrates upon the potential value of collaborative learning of medical students during their clinical clerkships. It is shown that a robust CSCL environment is an asset on students' collaborative learning and content-analysis was conducted by the identical system in every study. Although it is well known that a clinical clerkship is already a time-consuming activity for students, the participation rate was high. The voluntarily participation of students can be considered as a limitation of present study. Such a participation could have selected students who are motivated to participate actively. Furthermore, the chance to improve their task could provide students with a high motivation to participate to these studies.

Future research should focus on the role of factors as motivation and attitude, the role of a moderator, a varying level of structure, and providing effective feedback. Next, it would be challenging to identify the effect of knowledge transfer resulting in behavioral change of medical professionals from which patient care would benefit.

It can be concluded that CSCL appears to be a promising format to enable medical students in providing formative feedback on each other's written task during clinical workplace learning, and supports them to revise such a written task. 

Hoofdstuk 1 bevat de introductie, het doel en de algemene onderzoeksvraag van dit proefschrift.

In de afgelopen decennia is de zienswijze op leren en instructie in het hoger en universitair onderwijs radicaal veranderd. Het traditionele docent-gecentreerde onderwijs is geleidelijk vervangen door student-gecentreerde leeractiviteiten, er van uitgaande dat studenten voldoende competent zijn om hun leren zelfstandig te sturen. Deze benadering is afkomstig van het constructivisme, een onderwijs theorie die focust op een dynamisch en student-gecentreerd leerproces waarin studenten actief kennis construeren. Kennisconstructie omvat diverse activiteiten: 1) het aanvullen, uitwerken en evalueren van ideeën, 2) het samenvatten en evalueren van extern verkregen informatie, en 3) het verbinden van diverse feiten en nieuwe ideeën of concepten met de huidige kennis van de individuele student. Waar het constructivisme de kennisconstructie nog benadert als een individueel proces dat intern plaatsvindt bij de lerende, beschouwt het sociaal-constructivisme kennisconstructie als een sociaal proces dat deels ook extern, buiten de lerende plaatsvindt. Door in een sociale context, in samenwerking te leren met anderen, worden studenten gestimuleerd om een grotere en actievere rol te spelen in hun eigen leerproces en die van hun peers.

In een specifieke leeromgeving zoals werkplekleren is samenwerkend leren potentieel waardevol omdat juist bij werkplekleren studenten situaties tegenkomen die de werkelijkheid representeren en derhalve relevant zijn voor henzelf en voor hun medestudenten (peers). Echter, bij werkplekleren komt het vaak voor dat studenten zowel fysiek als in tijd verspreid zijn en efficiënt samenwerkend leren is daarom moeilijk te organiseren. In voorkomend geval kan een elektronisch leerplatform voor computerondersteund samenwerkend leren (Computer-Supported Collaborative Learning; CSCL) een uitkomst bieden. CSCL kan de sociale interactie faciliteren via een gestructureerde (asynchrone) discussie tussen peers. Zo wordt de mogelijkheid gecreëerd om studenten effectieve feedback te laten leveren op een leertaak en/of -ervaring van één of meerdere medestudenten. Het is aangetoond dat dergelijke activiteiten sterk bijdragen aan de individuele kennisconstructie.

Binnen de studie geneeskunde is het nog niet gebruikelijk om peer feedback te geven op een leertaak. Werkplek leren maakt een groot deel uit van deze studie waarbij het leerproces vooral bestaat uit werk-gerelateerde ervaringen. Deze ervaringen zijn vooral klinische problemen met een hoge werkelijkheidsgraad en zeer relevant voor een studenten zelf maar zeker ook voor hun peers. Onder dergelijke omstandigheden heeft samenwerkend leren een toegevoegde waarde door het stimuleren van kennisconstructie. Studenten geneeskunde kunnen in samenwerking leren door het actief bediscussieren van werk-gerelateerde ervaringen met behulp van een CSCL leeromgeving, zelfs wanneer studenten fysiek verspreid zijn over diverse werkplekken, ziekenhuizen of landen. Daarom is de hoofdvraag van dit proefschrift: 'In hoeverre draagt een asynchrone discussie in een CSCL leeromgeving op een positieve wijze bij aan het leerproces van studenten geneeskunde tijdens een klinische stage?'. 
De relevantie van dit proefschrift ligt in het rechtvaardigen (hoofdstuk 2 en 3) en het verhelderen (hoofdstuk 4 en 5) van de vraag hoe geneeskunde studenten samenwerkend leren aan een leertaak tijdens hun individuele klinische stage.

Hoofdstuk 2 beschrijft de resultaten van onderzoek met een 'mixed method' design naar de toegevoegde waarde van een gestructureerde asynchrone discussie van een authentieke werkplek-gerelateerde leertaak in een CSCL omgeving voor het leren in een klinische stage. De perceptie van de geneeskunde studenten over de aangeboden CSCL omgeving werd bevraagd (door middel van een vragenlijst en een semigestructureerd interview) op het gebied van voorbereiding, design van het forum, participatie, en ervaren kennisverbetering. Daarnaast werden de discussieberichten geanalyseerd om de interactie van de studenten te onderzoeken. De studenten vonden de voorbereiding op de discussie noodzakelijk en ervoeren kennisverbetering met betrekking tot hun leertaak. De discussie inhoud was vooral taakgericht. De kwantiteit van de verstuurde discussieberichten en de mate van activiteit tijdens de discussie lijken de percepties 'participatie' en 'kennisverbetering' positief te beïnvloeden. Deze resultaten suggereren dat $\mathrm{CSCL}$ een passende leeromgeving is voor het samenwerkend leren van studenten door middel van een asynchrone discussie, en waarin zij formatieve feedback geven op een relevante werkplek-gerelateerde leertaak.

Hoofdstuk 3 presenteert de bevindingen van een experimentele studie met betrekking tot de kennisconstructie van geneeskundestudenten tijdens een asynchrone CSCL discussie van een relevante werkplek-gerelateerde leertaak. Na de discussie werd de individuele student de mogelijkheid geboden zijn uitgeschreven leertaak aan te passen voor deze werd aangeboden aan een expert voor uiteindelijke cijfermatige beoordeling. Daarnaast werd door middel van een vragenlijst en een semigestructureerd interview de percepties van de student onderzocht op voorbereiding, design, participatie en kennisverbetering. De discussieberichten van de studenten werden geanalyseerd op inhoud, terwijl de kwaliteit van de leertaak onafhankelijk cijfermatig werd beoordeeld door twee ervaren stafleden. De analyse van de vragenlijst-items toonde positieve percepties op design, participatie, en kennisverbetering, waar na analyse van de interviews zowel positieve als ook negatieve percepties aan het licht kwamen. Content-analyse van de discussies liet significante hogere niveaus van kennisconstructie zien in de discussies die uiteindelijk leidden tot het reviseren van de leertaak. Er werden geen significante verschillen gevonden tussen de gepaarde beoordelingsscores van de leertaken voorafgaande aan de discussie en de gereviseerde leertaken na afloop van de discussie. We concluderen dat geneeskunde-studenten een positieve (subjectieve) perceptie hebben van de waarde van een gestructureerde asynchrone discussie van een werkplekgerelateerde leertaak. Studenten die hun taak reviseren op na afloop van een asynchrone CSCL discussie vertonen een significant hogere actieve kennisconstructie dan peers die besluiten hun leertaak niet te reviseren. 
In deze specifieke taak is actieve kennisconstructie niet per definitie gekoppeld aan een significant betere beoordelingsscore van een expert.

Hoofdstuk 4 beschrijft in meer detail of geneeskunde studenten tijdens werkplek leren na deelname aan een gestructureerde asynchrone discussie op een CSCL omgeving hun leertaak reviseren, meer intensief discussiëren en hogere niveaus van kennisconstructie bereiken dan studenten die hun leertaak niet reviseren. Hiertoe werden discussieberichten geanalyseerd op inhoud en gecategoriseerd in niveau van kennisconstructie. Daarnaast werd ieder discussiebericht toegewezen aan specifieke onderdelen van de leertaak. De resultaten tonen dat revisie van een leertaak geassocieerd is met een significant hoger aantal discussieberichten, hogere taakgerichte activiteit en bediscussiëring van specifieke onderdelen van een leertaak. We concluderen dat een CSCL omgeving geneeskundestudenten ondersteunt om een relevante leertaak uit te voeren tijdens het werkplek leren. Een hoge discussieactiviteit is positief gerelateerd aan een hoge hoeveelheid taak gerelateerde activiteit en aan een hoge hoeveelheid discussie over specifieke onderdelen van een leertaak.

Hoofdstuk 5 presenteert een onderzoek naar het effect van feedback door meerdere peers op de kwaliteit van een relevante leertaak in een $\mathrm{CSCL}$ omgeving tijdens het werkplek leren. In een gedetailleerd onderzoeksdesign werden drie fasen van een review opdracht onderzocht: 1) feedback op de leertaak door meerdere peers met behulp van een forum op een CSCL omgeving, 2) revisie van de leertaak als gevolg van feedback gegeven door meerdere peers, en 3) expert feedback op de leertaak na afloop van de discussie. Het resultaat van het review proces werd als winstgevend beschouwd indien er uiteindelijk geen expert feedback hoefde te worden geleverd op de leertaak. Het feedback proces werd daarentegen als inefficiënt beschouwd indien er uiteindelijk wel expert feedback werd gegeven op de leertaak. Zowel het volume als type van peer en expert feedback werden geanalyseerd. Feedback door meerdere peers werd gegeven op 39\% van alle leertaken, wat leidde tot revisie van één derde daarvan. Experts leverden feedback op 30\% van de uiteindelijke leertaken. $71 \%$ van deze taken waren niet gereviseerd na peer discussie. Peers en experts gaven in de meerderheid van de gevallen identieke waarderingen aan de verschillende onderdelen van een leertaak. Het type feedback dat experts aanleverden op gereviseerde en niet gereviseerde leertaken was niet verschillend, waarbij peers evenwel significant meer triviale commentaren aanleverden op leertaken die niet gereviseerd werden na discussie. Samenvattend kan men stellen dat studenten significante positieve bijdragen leveren aan de discussie van een complexe leertaak. Feedback door meerdere peers is daarom een effectieve methode om studenten te ondersteunen hun werkplek-gerelateerde taak te reviseren. Het terugbrengen van triviale commentaren tijdens peer feedback kan de discussie onder studenten bevorderen, evenals de revisie van de leertaak. 
Experts leveren vooral feedback op leertaken die niet zijn gereviseerd, waarbij de meerderheid van de leertaken geen expert feedback nodig hebben, ongeacht deze leertaken in een eerder stadium al zijn gereviseerd of niet.

Hoofdstuk 6 bediscussieert de belangrijkste resultaten met betrekking tot de onderzoeksvragen van dit proefschrift en presenteert de implicaties voor de onderwijspraktijk. Tevens worden de sterkte en beperkingen van dit onderzoek beschreven en worden er suggesties gedaan voor toekomstig onderzoek. Het hoofdstuk wordt afgesloten met een beschrijving van de belangrijkste conclusie van dit proefschrift.

De belangrijkste bevindingen die in dit hoofdstuk worden bediscussieerd zijn 1) de hoge mate van deelname aan de discussie door geneeskunde studenten en de positieve percepties van de studenten die kennisconstructie en taak verbetering bevorderen, 2) het verschil tussen de beoordelingen van een expert en de positieve perceptie van studenten op kennisverbetering, en feedback van studenten als een relevante indicator voor kennisverbetering, 3) het positieve effect van zowel een gestructureerde discussie als ook een script voor het niveau van kennisconstructie van een student, en 4) het voordeel van multiple-peer feedback voor de kwaliteit van een taak en het effect van multiple-peer feedback hiervan op expert feedback.

De belangrijkste implicatie voor onderwijs is dat een gestructureerde asynchrone discussie in een CSCL omgeving een potentiele waarde heeft om studenten geneeskunde te ondersteunen in hun leertaak, speciaal in een leeromgeving zoals een klinische stage.

Een sterke punt van ieder onderzoek in dit proefschrift is dat met een identiek systeem de content-analyse van de studenten feedback uitgevoerd en dat er gebruik is gemaakt van een gecontroleerde leeromgeving. Dit uitte zich in een gestructureerde discussie omgeving waarin de studenten met een script aan de leertaak hebben gewerkt. Doordat alle onderzoeken gefocust zijn geweest op de potentiele waarde van samenwerkend leren tijdens de klinische stages hebben we kunnen laten zien dat een robuuste CSCL omgeving een waarde is voor samenwerkend leren door studenten. Ondanks dat een klinische stages enorm veel tijd van een student in beslag neemt was de vrijwillige deelname aan de onderzoeken erg hoog. Dit zou kunnen worden beschouwd als een beperking in de onderzoeken van dit proefschrift. Zo'n vrijwillige participatie heeft namelijk kunnen leiden tot een selectie van gemotiveerde studenten die actief participeren om hun kennis te construeren en hun leertaak te verbeteren.

Toekomstig onderzoek zal zich kunnen richten op de rol van factoren zoals motivatie en attitude, de rol van de moderator, het aanbieden van een verschillende mate van structuur, en het aanleveren van effectieve feedback. Verder is het een uitdaging om te identificeren of het effect van een asynchrone discussie in CSCL een transfer van kennis resulteert zodanig dat er gedragsverandering ontstaat bij medische professionals zodat uiteindelijk de patiëntenzorg hiervan kan profiteren. 
Concluderend is CSCL een veelbelovend format om het studenten geneeskunde mogelijk te maken formatieve feedback te geven op elkaars leertaak tijdens klinisch werkplek leren en dat het hen ondersteunt om een leertaak te reviseren. 
De onderzoeksresultaten van dit proefschrift dragen bij aan en spelen in op de aansluiting van universitair onderwijs op de mogelijkheden die het internet en samenwerkend leren kunnen bieden aan studenten die op afstand en vaak op een individuele wijze hun studie vorm moeten geven.

\section{RELEVANTIE}

We leven in een samenleving waarin de digitalisering een steeds grotere rol speelt. Sinds de opkomst in de jaren '90 van het publiek internet gebruik is een compleet nieuwe wereld voor ons open gegaan. En nog steeds zijn de grenzen van het wereldwijde web niet bereikt. Volgens het rapport 'Measuring the Information Society Report 2014' van de International Telecommunications Union (ITU) was eind 2014 40\% (3 miljard) van de wereldbevolking online, en had $30 \%$ toegang tot het mobiele internet (http://www.itu.int/en/ITU-D/Statistics/Pages/publications/mis2014.aspx). Uit de cijfers van het Centraal Bureau voor de Statistiek (CBS) blijkt dat Nederland zich ver boven het wereldwijde gemiddelde bevindt, eind 2014 had al bijna 95\% van de Nederlandse bevolking toegang tot internet, en het gebruik van een smartphone en een laptop ontlopen elkaar nauwelijks met respectievelijk 78 en $80 \%$, waarbij $57 \%$ van de Nederlandse huishoudens een e-tablet gebruikte voor internet. Internet heeft intussen een dusdanige invloed op de wijze warop wij consumeren, werken, relaties onderhouden, onze vrije tijd besteden en informatie tot ons nemen, dat een wereld zonder digitalisering niet meer in te beelden is. Wij gebruiken (mobiele) internetapparaten om (veelvuldig) te communiceren via e-mail en What's app, maar ook via sociale media zoals o.a. Facebook, Twitter, LinkedIn, Tumblr, Snapchat en Instagram. Naar verwachting zal in de toekomst de afhankelijkheid van technologische ontwikkelingen en digitalisering alleen maar groter worden, en neemt hierdoor de dominantie van deze ontwikkelingen binnen de maatschappij verder toe.

\section{Doelgroepen}

In 2013 voerde de Universiteit Twente een onderzoek uit in opdracht van Digivaardig \& Digiveilig, een samenwerkingsverband tussen bedrijfsleven, overheid en maatschappelijke organisaties (https://ecp.nl/item/3978). De resultaten van dit onderzoek zijn beschreven in het document: "Zicht op ICT-competenties. Een werknemers en managers perspectief in zes sectoren". In dit onderzoek werden ruim 1200 Nederlanders uit alle sociale klassen en leeftijdscategorieën ondervraagd naar hun digitale communicatie. Daaruit blijkt dat er een opvallend verschil is tussen mensen met een hoog (HBO/WO) en laag opleidingsniveau (VMBO/MBO). Van de hoog opgeleiden gebruikt 99\% internet, in tegenstelling tot $83 \%$ onder laag geschoolden. 
Op werkdagen maken hoogopgeleiden veel meer gebruik van het internet dan laagopgeleiden, terwijl op vrije dagen dat juist omgekeerd is. Hoogopgeleiden gebruiken het internet vooral voor informatie, educatie en carrière, terwijl laagopgeleiden zich vooral richten op vermaak en gamen, chatten en het bekijken van online filmpjes. Hierdoor dreigt een digitale kloof te ontstaan tussen mensen met een verschillend opleidingsniveau en hebben hoogopgeleiden meer profijt van het internet (http://www.nu.nl/inter net/2958842/digitale-kloof-internetters-dreigt.html).

Daarnaast blijkt dat vooral jongeren internet niet alleen intensief gebruiken en maar ook vaak online zijn. Hierdoor hebben zij op ieder moment van de dag de beschikking over een grote hoeveelheid communicatiemogelijkheden en informatie.

Als gevolg van deze ontwikkelingen onder hoog opgeleiden en jongeren neem het belang van afstandsleren voor universiteiten en hogescholen verder toe. Het hoger onderwijs ziet online educatie doorgaans echter nog steeds als een toevoeging aan het traditionele universitaire lesprogramma in plaats van een vervanging. Deze traditionele benadering biedt zeker ook enkele voordelen want naast lesgeven (colleges en werkgroepen), examinering en diploma accreditatie, creëert universitair onderwijs ook sociale waarden bij een student. Studenten leren samenwerken, communiceren, debatteren en zichzelf te presenteren. De vraag is of digitale ervaringen deze activiteiten afdoende kunnen vervangen. Universiteiten over de hele wereld worstelen dan ook met het aanbieden van onderwijs via digitale weg. De noodzaak ervan wordt onderkend en het behalen van een universitaire graad via digitale kanalen staat volop in de belangstelling. Op het gebied van onderwijs staan Universiteiten een paradigma shift te wachten, of zoals The Economist schreef: 'een welkome aardbeving' (http://www.economist.com/ news/briefing/21605899-staid-higher-education-business-about-experience-welcomeearthquake-digital).

De onderzoeksresultaten van dit proefschrift zijn daarom niet enkel belangrijk voor studenten geneeskunde van de Maastricht University, maar ook voor geneeskunde opleidingen bij andere universiteiten warin afstandsleren een rol speelt. De onderzoeksresultaten dragen ook bij aan de algemeen gehoorde wens tot digitaliseren van universitair onderwijs, het online aanbieden van leermogelijkheden, en het afwijken van de bestaande roosters en onderwijstijden door het 24/7 verbonden zijn met de universiteit. Specifiek is dit beschreven in de paragraaf 'implicatie voor onderwijs' van hoofdstuk 6 van dit proefschrift.

\section{Activiteiten en producten}

De gebruikte onderwijsmethode samenwerkend leren met behulp van 'ComputerSupported Collaborative Learning' (CSCL) zoals beschreven in dit proefschrift kan op allerlei onderwijsgebieden worden ingezet. Een voorbeeld hiervan kan de inzet van CSCL zijn ter vervanging van fysieke terugkom momenten tijdens het werkplekleren. 
Studenten hoeven daardoor niet meer terug te reizen naar de universiteit voor groepsonderwijs maar kunnen deze opdrachten in samenwerking met peers op afstand vervullen. Ook valt te denken aan andere samenwerkingsopdrachten die efficiënt (op afstand) kunnen worden ingezet of aan individuele opdrachten die verrijkt of vervangen kunnen worden door asynchrone samenwerkingsopdrachten. Zo worden in de opleiding tot arts-klinisch onderzoeker (A-KO) van de FHML van de Maastricht University nu reeds alle onderzoeksprotocollen in samenwerking bediscussieerd via digitale weg. Een docent coördineert en begeleidt dit proces op afstand. Na afloop krijgen studenten de gelegenheid hun onderzoeksprotocollen op individuele basis te verbeteren en vervolgens voor eindbeoordeling in te sturen aan een expert. Doordat A-KO-studenten peer feedback op waarde leren schatten wordt deze activiteit een vaste bijdrage in het onderwijsproces en draagt zij bij aan een performant educatief proces

\section{INNOVATIE}

Onderwijskosten worden niet alleen bepaald door personeelssalarissen en administratie, maar ook door technologische investeringen die digitalisering vereist. Doorgaans is het bestaande onderwijsaanbod aan studenten die zich op afstand van de universiteit bevinden nog zo georganiseerd dat individuele plaatsgebonden opdrachten moeten worden uitgevoerd, en/of dat studenten moeten terugreizen naar de universiteit om in samenwerking met peers een opdracht uit te voeren. Door technologische ontwikkelingen en digitalisering kunnen we studenten op afstand verbinden zodat ze digitaal in samenwerking met elkaar aan een opdracht werken. Hierdoor kan de tijd van studenten en docenten efficiënter worden benut. Als daarnaast de opdracht zodanig via digitale wijze is ingericht dat een student de universitaire openingstijden kan loslaten en op eigen tijd en op een eigen plek kan samenwerken met peers wordt het onderwijs flexibeler en te allen tijden bereikbaar. Dit onderwijs kan vervolgens gecombineerd worden met het huidige bestaande (klassieke) onderwijs, waardoor een zogenaamde blended leeromgeving ontstaat. Wereldwijd hebben een groot aantal universiteiten al digitale klassen of digitale methodieken toegevoegd aan hun curriculum. In Nederland is hier ook grote belangstelling voor, ruim 30 universiteiten en hogescholen hebben subsidie aangevraagd voor open en online onderwijs (Onderwijsnieuws in Onderwijsinnovatie Open Universiteit, maart 2015, nr.1). Studenten kunnen hierdoor online - en vaak ook gratis - leergangen op afstand volgen en in samenwerking opdrachten maken zelfs terwijl ze voor bijvoorbeeld een stage in een ander land zijn. Studenten die naast een online programma met peers samenwerken halen vaak een betere beoordeling op de leertaak ('MOOC's: docenten en deelnemers II', Onderzoeksnieuws in Onderwijsinnovatie Open Universiteit, september 2014, nr. 3). Ondersteuning van peers en van expert blijft daarbij belangrijk maar kan wel anders worden ingericht dan tot nu gebruikelijk is. 
Een student kan niet alleen vertrouwen op peer feedback als een kritische beoordeling van het eigen werk, maar ook dat de eigen feedback bijdraagt aan de ontwikkeling van peers. Een expert zou er op moeten vertrouwen dat de intensieve fase van kennisconstructie en productbijstelling kan worden overlaten aan peers. Een expert kan het proces van peers onderling op afstand volgen en eventueel bijsturen indien dit nodig is ('Ook online moeten docenten goed voorbereid zijn', Onderzoeksnieuws in Onderwijsinnovatie Open Universiteit, maart 2015, nr. 1). Ook hierdoor kan de studietijd van studenten en de begeleidings- en beoordelingstijd van docenten efficiënter worden benut.

\section{PLANNING \& REALISATIE}

Doordat eerdere onderzoeken daadwerkelijke positieve resultaten opleverden uitgedrukt in kwalitatief goede onderzoeksprotocollen is het computer ondersteund samenwerkend leren op dit moment al een gebruikelijke manier om onderzoeksprotocollen door A-KO studenten te bediscussiëren. Ook in andere onderwijsomgevingen kan deze methode zeer nuttig zijn. Belangrijk daarbij is dat de studenten die deelnemen aan een opdracht op een CSCL omgeving goed moeten worden geïnstrueerd en ook doordrongen moeten zijn van een eigen positieve en actieve bijdrage aan de discussie op de elektronische leeromgeving. Doordat gebruik is gemaakt van de bestaande elektronische leeromgeving Blackboard (c) zijn er voor de universiteit Maastricht geen extra kosten verbonden aan deze onderwijsmethode. Andere organisaties kunnen wellicht ook zonder extra kosten gebruik maken van een eigen elektronische leeromgeving of zullen een eigen systeem moeten aanschaffen waardoor wel extra kosten ontstaan. Op dit moment staat vervolgonderzoek naar CSCL al gepland. Enerzijds zal dit gebeuren door andere variabelen uit het leerproces te onderzoeken, maar ook door analyse van al bestaande data. 

Dit proefschrift is ontstaan vanuit mijn studie onderwijskunde. Terwijl ik op zoek was naar een opdracht voor mijn afstudeerstage werd ik namens Máxima Medisch Centrum lid van de planningsgroep geneeskunde jaar 6. Prof. dr. Luc Snoeckx was destijds voorzitter van de planningsgroep en mijn afstudeerstage kwam ter sprake. Luc had daar wel een interessant idee voor; de bedoeling was dat ik een onderzoek zou uitvoeren naar de percepties van studenten die online op een asynchrone wijze met elkaar een taak discussieerden. Deze taak was een Critical Appraisal of a Topic (CAT), een taak die $6^{e}$ jaars geneeskunde studenten normaal gesproken op individuele basis uitwerken tijdens een klinische stage. Ik zou een opdracht schrijven voor de discussie van deze taak, ik zou de discussie begeleiden én na afloop de discussie evalueren met de betrokken studenten. Nadat uit het onderzoek bleek dat studenten zo'n online asynchrone discussie erg nuttig vonden voor hun leerproces wilden we de voordelen hiervan graag verder onderzoeken. We zijn dit toen met prof. dr. Cees van der Vleuten gaan bespreken, en al snel was ik met het eerste onderzoek van dit proefschrift aan de slag.

Het uiteindelijke resultaat, dit proefschrift, had ik niet kunnen schrijven zonder de directe en indirecte steun én stimulans van een heel aantal mensen om mij heen, waarvan ik hieronder een aantal in het bijzonder wil bedanken. Vanzelfsprekend worden mijn promotoren prof. dr. Luc Snoeckx en prof. dr. Cees van der Vleuten, en mijn copromotor, dr. Bas de Leng hartelijk bedankt voor alle ondersteuning.

Beste Luc, jij bent tijdens alle onderzoeken en het daarbij behorende schrijfwerk mijn dagelijkse begeleider geweest. Jouw ondersteuning, coaching, stimulans en kritisch redigeerwerk is onontbeerlijk gebleken. In het begin vond dit plaats op de afdeling fysiologie, en na je pensionering was ik - onder het genot van koffie en chocolade - welkom bij jou thuis in Hasselt. Voor deze gastvrijheid wil ik ook graag je vrouw Agnes bedanken, zij heeft mijn bezoeken toch altijd maar voor lief moeten nemen. Naast mijn begeleider ben je als coördinator van geneeskunde jaar 6 een enorme stimulans geweest in de deelname van geneeskunde studenten aan diverse onderzoeken.

Beste Cees, ik wil jou graag bedanken voor je kritische blik op mijn onderzoeken, voor je lastige vragen en de soms moeilijke keuzes die je aan mij hebt voorgelegd. Ik was er op dat moment niet altijd even blij mee. Meestal vertrok ik uit ons overleg met meer vragen dan het aantal waarmee ik binnen gekomen was, maar dat heeft uiteindelijk zeker bijgedragen aan het eindresultaat.

Beste Bas, tot aan je vertrek naar de Universiteit van Münster heb je regelmatig tijd in je agenda vrijgemaakt voor feedback op mijn onderzoeksopzetten en -artikelen, bedankt!

Zonder de geneeskunde studenten die de afgelopen jaren hebben meegewerkt aan de diverse onderzoeken was dit proefschrift er niet gekomen, jullie worden allemaal heel erg bedankt voor je inspanning!

Dr. Wilfred Germeraad, dr. Kitty Cleutjens, dr. Daniel Kotz en dr. Adri de Voogd worden hartelijk bedankt voor het stimuleren van geneeskunde studenten tot deelname 
aan het onderzoek, én voor het opnemen van de discussie opdracht als vast onderdeel van het geneeskunde curriculum voor arts-klinisch onderzoeker (AKO).

Mijn collega's uit het Máxima Medisch Centrum wil ik bedanken voor de ondersteuning, samenwerking en gezelligheid die ze mij de afgelopen jaren hebben gegeven.

Natuurlijk wil ik ook heel graag mijn vrienden en familie bedanken. Dit zijn de mensen die mij al jaren weten af te leiden van de beslommeringen en worstelingen met betrekking tot het uitvoeren van onderzoek en het promoveren in het bijzonder.

Annemieke en Hanco, jullie zijn mijn paranimfen en dat is (uiteraard) niet zomaar. Annemieke, jouw steun tijdens een kritiek moment in mijn leven waardeer ik nog altijd enorm! Hanco, jouw evenwichtige karakter én je zorgvuldigheid in de relatie met anderen om je heen vind ik een zeer positief voorbeeld voor velen.

Ronald en Ellen en Hanco en Martine, bedankt voor alle afleiding die jullie mij geven. Ik zou zeggen: 'neem er nog maar één, maar niet de laatste want die nekt je altijd'.

Mijn squash maten, Ronald en Patrick worden bedankt voor een wekelijks sportief uitje waar in ieder geval het publiek altijd de winnaar is, én daarnaast ook voor het op simpele en effectieve wijze oplossen van wereldproblemen.

Hé Ben, ouwe reus, bedankt voor je (emotionele) steun, je humor en je directheid. Onze ongeregelde vriendschap gaat toch al lang mee! Ik zie nog steeds voor me hoe wij op de afdeling cardiologie in het holst van de nacht rondreden in een elektrische rolstoel met daarachter een bureaustoel gebonden, omdat we te lui waren om lopend de infuuszakken van onze patiënten te verwisselen.

Lieve zus en broers, Annemieke en Mark (en Tim en Famke), Maarten en Katharina (en Liam en Casper), René en Sandra (en Daniël en Rachel), ook al leven we ons eigen leven en zijn we ook nog eens (geografisch) verwijderd van elkaar, toch voel ik me sterk met jullie verbonden. Het voelt altijd vertrouwd wanneer we bij elkaar zijn en dat vind ik heel bijzonder! Ik wil jullie heel erg bedanken voor alle steun tijdens, voor mij persoonlijk, moeilijke tijden. Hierdoor ben ik sterker geworden, en ieder van jullie heeft daar op zijn of haar eigen, unieke manier aan bijgedragen.

Lieve Evelyne, wat een wonder dat wij elkaar zijn tegengekomen!! We spreken dezelfde taal en hebben toch ieder onze eigen woorden. Maar toch 'verstaan' wij elkaar heel goed, ondanks (of dankzij) onze spraakwatervallen, onze van de hak op de tak associaties, en onze fantasie en creativiteit. Oh ja: 'niets moet, alles mag'.

Lieve papa en mama, jullie zijn het echte voorbeeld van ouders die zorgen voor hun kinderen tijdens alle momenten van het leven. Ik hoop dat we nog heel lang van elkaars gezelschap mogen genieten want jullie zijn héél erg speciaal voor mij.

Lieve Maartje en Marijn, jullie hebben je beide op een heel volwassen manier door een zeer moeilijke tijd geworsteld, en daar ben ik heel erg trots op! Ik kijk er nu al naar uit om jullie verder te zien (op)groeien tot een verantwoordelijke zelfstandige volwassene. Ook de komende jaren hoop ik daar nog een steentje aan te kunnen bijdragen. 
Voor allen die dit dankwoord lezen en die hun naam niet hebben gezien, voel je niet tekort gedaan en troost je met de gedachten dat ook jij hebt bijgedragen aan dit eindresultaat. 


\section{Curriculum Vitae}

The author is this dissertation, Willem (Jan) Koops was born on October $7^{\text {th }}, 1972$ in Hasselt near Zwolle, The Netherlands. After completing his secondary education, he studied Nursing at the St. Joseph Hospital in Veldhoven (nowadays Máxima Medical Center).

While he was working as a nurse at the cardiology ward of Máxima Medical Center in Veldhoven, he studied teaching at the Utrecht School for applied sciences. During this study, he changed jobs within the hospital organization and became an consultant in education to students, supervisors and management of the organization.

In September 2001 he enrolled in the master program of Educational Sciences at the University of Utrecht. During this masterstudy he conducted research on the influence of curriculum changes on medical work-based learning by residents and realized his work placement by an assignment to design a task for distance learning under the supervision of Luc Snoeckx, PhD. and professor in physiology at the department of physiology of the Faculty of Health, Medicine and Life Sciences at the Maastricht University. During his master study his job assignment changed to support the quality of medical education in Máxima Medical Center. After obtaining his master's degree in July 2006 he started working to improve the quality of work-based learning by medical students and residents in education for every (medical) specialism in Máxima Medical Center in Veldhoven.

From 2006 till 2008 he conducted research in the field of online asynchronous discussion within a Computer-Supported Collaborative Learning environment under the supervision of prof. dr. Luc Snoeckx which resulted in a PhD project which he conducted beside his job in Máxima Medical Center.

At this moment Willem works as an Educational Scientist and consultant for medical education in Máxima Medical Center. As a project leader he is currently involved in the upgrade of the educational and professional level of nursing practice. Furthermore, he is involved as a member in the consulting group of the sixth (last) year of medicine, in the regional planning and finance consulting forum of the Maastricht University Hospital considering medical specialism. 


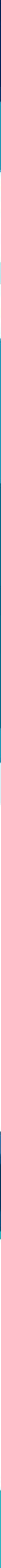

